\title{
Method and Theory of Early Farming: The Orinoco and Caribbean Coasts of South America
}

\author{
Anna C. Roosevelt ${ }^{1}$ \\ ${ }^{1}$ Department of Anthropology, University of Illinois at Chicago, U.S.A. \\ Correspondence: Anna C. Roosevelt, Department of Anthropology, University of Illinois at Chicago, Behavioral \\ Sciences Building Room 2102, MC-027, 1007 West Harrison Street, Chicago, Illinois 60607-7139, U.S.A. Tel: \\ 1-312-413-3570. E-mail: annaroosevelt@gmail.com
}

Received: April 24, 2016

Accepted: May 10, $2016 \quad$ Online Published: November 5, 2016

doi:10.5539/esr.v6n1p1

URL: http://dx.doi.org/10.5539/esr.v6n1p1

\begin{abstract}
The early and mid 20th century was a time of great interest in the rise of agriculture and its role in the evolution of civilizations societies in particular environments. Late 20th century efforts to reconstruct the nature and history of prehistoric farming societies in the northern lowlands of South America ranged from expansive hypotheses to regional case studies using archaeobotanical technologies then available. Since 2000, a large number of regional studies using expanded and refined methods have produced broadly interesting results. Approaches from the fields of geography and earth sciences are being recruited increasingly. The resulting empirical evidence does shed light on aspects of the history of human use of some plants but, as always, has raised more questions than it solved. Many of the problems interpreting the processual and evolutionary significance of these findings are methodological ones. This article reviews what seem to be the most important methodological and interpretive issues of this area of research for the tropical lowlands (up to c. $1500 \mathrm{~m}$ a.s.l) of northern South America.
\end{abstract}

Keywords: Orinoco, Caribbean coast, maize, prehistory, taphonomy, neotropics, farming, archaeobotany, archaeology

\section{Introduction}

\subsection{Paradigms for Research on Early Farming}

Archaeologists' engagement with early prehistoric agriculture has involved theories of human evolution and models of systematic change through time in the relationship of subsistence and society. In the post-World-War-2 era, American anthropologists and geographers were obsessed with population growth, agriculture, and their roles in the rise of the state and urban civilization, i.e.: of our kind of society. One or all of these were the topics of choice for many researchers (Adams, 1966; Braidwood \& Reed, 1957; Carneiro, 1970; Flannery, 1965, 1973; Fried, 1967; Harris, 1968; Lathrap, 1970; MacNeish, 1965; Sauer, 1952; Service, 1975). That era, of which I was a latter-day member (Roosevelt, 1980), overestimated the importance of agriculture as a response to demographic growth and as the economy of early complex societies. Extensive paleopathological research worldwide does not support the hypothesis that agriculture was devised to furnish more food for starving foragers (Roosevelt, 1984b). Evidence for dietary inadequacies are uncommon before the rise of agricultural economies but are common afterwards. We tended to underestimate the sophistication and productivity of intensive foraging and its ability to support sedentary populations and complex heterarchical organizations (as Arnold, 1996 points out). Theorists also tended to underestimate the managerial effectiveness small-scale organizations compared to states and chiefdoms, assuming that the former would be necessarily be egalitarian "village" societies unable to organize and underwrite monumental projects.

Environmental determinism was an influential notion in that earlier phase of theoretical applications and still is in some quarters. The choices that prehistoric people made were assumed to have been conditioned, even caused by, their environment. In that intellectual era, most researchers assumed that drier, cooler, more open habitats were centers of plant domestication and state formation. In contrast, tropical forests and savannas were assumed to have received their cultigens from those outside habitats because their own soils were considered too poor to allow incipient horticulture and the intensive agriculture that state formation required.Scholars' search for origins therefore focused on the few plants that had become important staples in late prehistoric complex societies and 
civilizations and in modern globalized industry, but it's now clear that the earliest cultivation did not necessarily privilege these plants (Oliver, 2008). It's also now recognized that cultigens like maize, earlier assumed to have been domesticated in dry, open, upland habitats in central Mexico, may have originated in the humid lowland tropics (Piperno \& Pearsall, 1998), an insight that has, however, not yet shed light on what the process of crop development in the lowlands might have been like. Furthermore, slash and burn agriculture was not always the main kind of tropical forest cultivation, as it often is in the more open habitats of today's tropical nations; slash and mulch is an effective method in very high-rain areas rainforest in Colombia and Ecuador (Orejuela, 1992). Ancient tropical forest villages preserved by volcanic eruptions in central America turned out to have permanent agricultural fields (Lentz, Beaudry-Corbett, de Aguilar, \& Kaplan, 1996; Sheets, Dixon, Guerra, \& Blanford, 2011), and tree and palm agroforestry is a still-persistent indigenous system likely to have been an ancient form of permanent cultivation (Politis, 2009; Roosevelt, 2014). The long-lasting systems of intensive tree and shrub management and fishing uncovered through CRM research in the Archaic of Louisiana (Fritz, 2007) could be useful models to test in future research in lowland South America.

A form of evolutionary environmental determinism was important in modeling the origins of agriculture. As in behaviorist approaches popular in the mid-20th century, cultivation was seen as arising first from inadvertent human effects on the environment that then led to physiological and genetic changes in plants, which humans only later selected for collection, leading to further changes culminating in plants that required human intervention to reproduce (Rindos, 1984). Complicating this model are more recent data showing the unsuspected extent of purposeful human interventions in world environments (Erlandson \& Braje, 2013). Cultural ecology thus turns out to be a more useful and holistic paradigm than environmental determinism for research on the origins and consequences of agriculture. This paradigm represents humans' relationships to habitat as always mediated by culture, and considers habitats to be fully integrated into culture and social organization, as the human frameworks through which habitat is viewed and imaged (e.g., Rival \& McKey, 2008). Unlike cultural ecology, the popular theoretical movement of historical ecology (e.g., Erickson, 2008) is not explicitly tied to the overarching phenomena of long-term cultural and biological evolution. Without that link, regional histories proliferate, without clarifying the fundamental processes at work in systematic change worldwide in human-environment interaction.

Since the old days, researchers have branched out to investigate the ways that social, political, and ideological cultures are linked to the development and dissemination of domestic plants and their uses. Now that social complexity finally has became recognized as having developed in the tropical forests and savannas of the Orinoco and Amazon, it has been assigned to chiefdom or complex chiefdom levels, continuing the idea that those habitats did not permit state development (e.g., Moore, 2014). Systematic comparison of complex societies in different environmental zones, however, has not yet solved that paradox, and societies are still categorized more by their habitats than by their forms (Roosevelt, 1991). Early on, there was much theorizing about the role of migration in sociocultural, political, and economic development in lowland South America (e.g., Lathrap, 1970; Rouse \& Cruxent, 1963), without much empirical testing of the implications of those theories. Theories about Greater Amazonia were a branch of the global theorizing that language, ethnic groups, and art styles moved together lock-step in the spread of farming systems (e.g., Diamond \& Bellwood, 2003). Some recent reviews on the northern lowlands have found the grand old schemes wanting (e.g., Gassón, 2000; Navarrete, 2008). Processes of acculturation and exchange rather than solely migration may be important processes for understanding cross-regional similarities (Roosevelt, 1997, pp. 170-176). However, the current accrued evidence about the cultures in the northern South American lowlands, does offer much information relevant to issues about plants and evolution there, whether the issues are those raised earlier or new ones. This paper will attempt to evaluate the rather disparate data from the area from that point of view.

\subsection{Epistemology of Early Agriculture in the Tropical Lowlands}

The field of archaeobotany (aka paleoethnobotany) has produced new information about the history of human plant use in prehistory (Fritz, 2005; Hastorf \& Popper, 1988; Hather, 2010; Pearsall, 2000, 2007; Piperno, 2006; Piperno \& Pearsall, 1998; Wright, 2010). But there are still serious empirical problems hampering understanding of the early history of plant domestication that need to be sorted out before there can by any definitive patterns to compare and interpret (Fritz, 2005; Langlie, Mueller, Spengler, \& Fritz, 2014). For example, the domestication of maize is still inadequately reconstructed, and there are strong conflicting opinions about the crops' development (c.f., Buckler \& Stevens, 2006; Eubanks, 2006). These empirical problems are related to epistemology: the issue of how we can know things scientifically. Methodological issues include sampling, identification, dating, provenience and stratigraphic relationships, quantification, and habitat reconstruction. We still have very different information about plant use from different areas and times: lack of sequence information 
in some, only plant macrospecimens from others, only microfossils in others, lack of human stable isotope ratios in most, and lack of comprehensive information on local sociopolitical organization and paleoenvironments in all areas.

\section{Background and Methodology}

\subsection{Environment}

The background of any inquiry on history of plants in human societies in particular regions is history of the environment. It used to be that archaeologists and botanists would use the modern habitat as a proxy for the ancient ones. But today's environments cannot easily be projected backwards because of important recent human impacts (Roosevelt, 2014), which explanations of current environments tend to minimize or ignore (e.g., Medina, 1980; van der Hammen \& Hooghiemstra, 2000) and which many archaeological analyses don't take into consideration (e.g., Pohl, Piperno, Pope, \& Jones, 2007). Many tropical lowlands tend to be drier now than in the past, due to recent wide deforestation, which lowers rainfall, locally, especially in the areas of prehistoric raised fields, which for centuries have been intensively cut and burned for cattle ranching and plantation agriculture. The human use of fire in such wetland areas has been much greater since the conquest (e.g., Iriarte et al., 2012). Some of the supposedly natural, climate-caused savannas in the South American northern lowlands are actually intensively managed cattle pastures (Migliazza, 1985) and may not have been open savannas before the conquest (Roosevelt, 2014). In addition, rapidly fluctuating seasonal floodplains in high-rain areas of northern South America support diverse herb-dominant communities yet are hardly archetypal climatic savannas. Nonetheless, ancient pollen-core zones with such communities are usually classified by palynologists as savannas (Roosevelt, 2014). Another problem for habitat reconstruction is that so-called "savanna" species identified in pollen cores are also integral parts of current forest habitats, as the denizens of early succession stages after disturbance (Lorenzi, 2002; Pires, 1984). Furthermore, ancient habitats are likely to have included regional groupings of plants that may no longer exist. Thus the structure of an ancient habitat, i.e., whether it was a dense forest community, herbaceous meadow, or something in-between, must be investigated independently of mere "index" or "type" species identifications.

For many reasons, then, the complexity of climate/hydrology/soil/plant/animal/human interactions through time means that modern tropical vegetation communities are rarely exactly the same as ancient ones, even when they share many of the same species. Community structure and patterns of taxonomic dominance have varied greatly through history and prehistory. Therefore, comprehensive studies are needed to evaluate the structure and composition of vegetation at the different times of interest. Even more important, ethnobotanists and geographers have discovered by actualistic studies that many tropical forest communities are distinctly anthropic in that they contain purposeful plantings by people as well as plant groupings created unintentionally by human activities (references summarized in Roosevelt, 2014). Furthermore, modern distribution of "wild" plants is heavily affected by human manipulations as well as by interactions with cultivated species, yet researchers usually treat distributions as a product of "natural" processes, as in the interpretation of savannas as natural formations or non-field Manihot species as "wild" manioc species (e.g., Schaal, Olsen, \& Carvalho, 2006). All such interpretive problems lead to problematic reconstructions of prehistoric habitats, their plants, and their long-term relationships with humans (Roosevelt, 2014, pp. 72-73).

\subsection{Stratigraphy}

Another necessary background for research on histories of plant use is archaeological and geological stratigraphy, an important part of the taphonomic record of how materials get buried in the ground. (Taphos is Greek for a burial.) To recover, depict, and interpret stratigraphy, however, certain excavation operations are needed that are often not accomplished. Both natural and cultural layers usually do not exist as level uniform, level structures. But the artificial excavation levels used by many excavators are uniform and horizontal. Therefore, excavation mixed deposits of different age and function, confusing the history of plant use and the associated artifacts. Sediments and objects must be separately collected and recorded by the strata and features that relate to ancient processes of interest. Conclusions about the age of plant microfossil remains from early strata not kept separate from intrusions during excavation are not valid. Intensive dating of layers in archaeological sites and in sediment cores commonly show significant disturbance and mixture, despite researchers' insistence that this does not happen (e.g., Pohl, Piperno, Pope, \& Jones, 2007). Claims for very early agriculture are often based on contexts that the excavators admitted were highly insecure stratigraphically (e.g., Fritz, 1994b). Yet out-of-order dates are simply rejected by researchers, and the occurrence of plant fossils interpreted without taking into consideration that sediment of different ages has become mixed. Moreover, the powerful motorized coring devices often used by palynologists definitely create downward movement of soil and therefore of macro and microfossils. Certain 
important humid tropical soil formation processes that change location of both macro and microfossils between strata also must be recognized and dealt with, as must the effects of associated geological substrates, chemical weathering patterns, neo-tectonic movements, and bio-intrusions such as roots and burrows. Consequently, identifications of very rare microfossils from such contexts are not reliable evidence for the age of a supposed cultivated taxon. However, the obvious mixture in many sites is rarely discussed in the interpretations of histories of plant use, and, even if it is discussed in primary monographs on research, it is usually left out of the summary articles in international journals.

Geological, geomorphological, and biological effects on the isotopic values of sediments, plants, animals, and humans also complicate inferences about ecosystem and plant community structures for habitat reconstruction and quantification of diets. Plant roots and animal burrows move soil and objects around in the ground, and common chemical weathering processes under rain forest, such as eluviation and illuviation, move fine particles downward, including microfossils (Roosevelt, 2014, pp. 70-72). These clay-size particles are observable as fine, thin coatings upon artifacts, plant and animal remains, and soil layers. Pollen also moves with water down through the soil profile at a rate of c. 1 meter each 1000 years, becoming concentrated in lower levels (Dimbleby, 1985, p. 59; Kelso, 1994; Piperno, 1995), and, though phytoliths are sometimes argued to be much less mobile (Piperno, 2006), they nonetheless have been shown to move downwards in archaeological sites and experimental sites (Fishkis, Ingwersen, \& Streck, 2009; Hart \& Humphreys, 1997; Osterrieth, Madella, Zurro, \& Alvarez, 2009), and direct dating of aggregates of them reveals significant stratigraphic displacement compared to other dated ecofacts (Piperno \& Becker, 1996). While it's claimed that such pedological processes "simply do not apply to starch grains by any circumstance" (Pagán-Jiménez, 2012, p. 80), starch grains indeed are found to move downwards in archaeological sites through the translocation of clays, which adsorb starch grains (Haslam, 2004). And starch grains of different sizes move downward at different rates (Therin, Fullagar, \& Torrence, 1999). Thus, it should be expected that microfossils retrieved from excavated sediment or artifacts may well have moved down from the layers and features in which they were originally deposited. Thus, the specimens that occur together in archaeological layers may be of different original provenances and therefore of different ages.

\subsection{Dating}

All the issues discussed in section 2.2 are involved in problems assessing the age and significance of objects of interest. Depending on stratigraphy, weathering patterns, bioturbation, and cultural processes, materials dated are not necessarily the same age as associated plants or human remains. Descent processes place recent objects and materials into ancient strata. Extraneous geological materials that enter objects during prehistory, such as calcium carbonate or petroleum materials, which are widely distributed through the northern lowlands, can create too-old radiocarbon dates (1). Although most petrochemicals mined industrially are deep beneath the surface in the Orinoco, lignite, lignitic, semi-bituminous coal and asphalt outcrop in many places drained by Orinoco tributaries, in its mouth area, in Trinidad, and in the Guyanas (Kugler, 1956; Leidelmeyer, 1966; Liddle, 1946, pp. 575-582, 593-679, 790-794, and Fig. 12; Lopez, Hedberg, \& Kehrer, 1956, pp. 327-350). Coal and petrochemicals also are exposed and redeposited by Colombian rivers draining into the Caribbean (Olsson, 1956, pp. 293-326). Such materials are found as coatings on pottery (Oliver, 2014, pp. 99-104, Tables 4 and 5), as carvings (Fewkes, 1914; Roosevelt, 1980), and, occasionally, collected in large masses, for probable fuel (Roosevelt, 1980; 1997, pp. 73-87). For its weight, low-grade coal burns much longer than wood and is a fibrous, black material often mistaken for charcoal. When archaeologists run dates on assemblages of unidentified black bits in this region they run the risk of incurring imprecise or irrelevant dates, which can mislead the reconstruction of archaeological and palynological sequences.

Because many of the layers in archaeological sites and sediment cores are not dated, ages that researchers quote for finds are often extrapolations from dates in other layers (e.g., Bush, Piperno \& Colinvaux, 1989). But the amounts of time that different layers represent are very different, so such extrapolations are not valid ages. Both different cultures and different environments produce contrasting thickness and density of sediment deposits per unit time. Also, the site formation processes discussed in the section 2.2 on stratigraphy, mean that materials move around in archaeological sites. An object from a dated stratum or with dated artifacts is not proven to be the same age unless dated directly. Critical re-study of the paleoethnobotanical record has shown by direct dates on macroplants by accelerator that they are often much younger than associated charcoal and artifacts in the layer (Fritz, 1994a; 2005). The drastic up-dating of the supposed early maize from highland Central Mexico is a good example. Tiny primitive cobs assumed to be early Archaic age from dates on associated charcoal instead gave early Formative dates than the associated charcoal. Direct dates show that the cobs are now only between 4700-5400 BP at the earliest, roughly 2000 to 3000 years younger than the layers they were in (Langlie et al., 2014, p. 1602; Piperno \& Flannery, 2001). In addition to the descent of prehistoric specimens from higher to 
lower levels in sites, some plants, like maize, were been widely and intensively cultivated in late prehistory and historic times, so there's the potential for their remains to get from the surface into archaeological sites. That recent plants remains routinely get into archaeological deposits is show by their ubiquity in soil flotation light fractions.

Another example of this problem is the dating and re-dating of La Gruta phase date samples from the middle Orinoco. Conventional dates on grouped charcoals dated early to mid Formative but accelerator dating of individual specimens from remaining groups showed that the groups included dates in the early Formative, terminal prehistoric, and post-conquest (Roosevelt, 1997, pp. 196-198). Only series of multiple dates on individual objects for each occupation strata can confirm age by exposing or eliminating inconsistencies (Méndez, 2013, p. 62). But in most strata profiles and sediment cores representing history of plant use in the northern lowlands there still are only a minority of strata with even one or two dates; the rest have extrapolated ages, despite clear evidence for changing sedimentation rates. In addition to the need for multiple dates, it's important to date identified single specimens of short-lived botanical parts, bones, teeth, or identified flora or fauna, spicules, caraipe, charcoal from artifacts, to compare to charcoal dates, which might have come from long-lived trees. In areas with a history of vulcanism, such as upland Colombia, argon-argon dating could help clarify chronologies but has not been used so far.

\subsection{Identification of Plant Remains}

The interpretation of botanical finds often is complicated because of the non-comparability of site records. Multiple proxies are rarely available because the intensiveness of sampling for identifiable plant specimens from sites is uneven, as are the use of methods for the purpose. Mid-to-late 20th century research showed the error of assuming plant and faunal remains were not abundantly preserved in humid tropical sites (Piperno \& Pearsall, 1998; Roosevelt, 1980; 1984b), but researchers sometimes claim that macroplants are not usually preserved in rainy tropical sites (Iriarte, 2007, p. 168; Torrence \& Barton 2006 passim). Carbonized macroplants, useful because single taxonomically identified specimens can be directly dated, are recovered in much larger quantities by hand during excavation than by selective soil flotation (e.g., Spencer \& Redmond, 2014, pp. 862-877), but soil flotation often recovers types of material rare among finds uncovered during excavation (e.g., Lentz et al., 1996). Intensive, exhaustive soil flotation and dry fine-screening can produce large samples of carbonized macroplants but are rarely carried out, making comparisons of patterns of finds difficult between sites excavated with different methods (Garson, 1980). Unfortunately, many excavators don't collect carbonized plants exhaustively, but any site that produced charcoal for dating is likely to have other kinds of carbonized plant remains also, regardless of what the excavators say.

The secure identification of ancient plant remains is itself very difficult no matter what the type of material (Langlie et al., 2014; Shillito, 2013). Most claims for finds of very ancient cultigens are based on microfossil identifications that are accurate only to family, or at best genus (Crowther, Haslam, Oakden, Walde, Mercadern, 2014 , p. 101). Conclusions for species level identifications and cultivation status from such specimens require risky interpretive extrapolations, such as that a plant from a certain family is not local so therefore it must be an introduced cultigen species (e.g., Piperno, 2011). Such assumptions don't take into account that modern distributions may not be representative of ancient ones (Langlie et al., 2014). Ancient remains often differ inscrutably from modern reference collections, making their identity mysterious (e.g., Spencer \& Redmond, 2014: 844-848). Microfossil identifications often rely on assumptions about the frequency of certain shapes in different species, yet the occurrence of such differences is not well established experimentally, and often the number of microfossils identified is so small that the frequency comparisons are not statistically viable (Shillito 2013).

Not infrequently, preliminary tentative identifications are not confirmed. The identification of carbonized maize from a Lesser Antillean site turned out to be erroneous (Newsom 2006, p. 329). A set of Archaic Colombian specimens initially thought by archaeobotanists to be palm seeds were later concluded to be avocado pits (Gnecco, 2000, p. 68; Herrera, Bray, Schrimpff, \& Botero, 1992; Piperno \& Pearsall, 1998, pp. 199-203; Schrimpff, Herrera, \& Bray, 2005, pp. 32-35, and note 24), despite the very different anatomy of the taxa. Specimens originally identified as the tips of corn cobs (Walton Galinat, personal communication, 1992) could not be corn, for they had $\mathrm{C}_{3}$ plant stable carbon isotope ratios on analysis (Geochron Laboratories). The fact that carbonized palm inflorescences are very similar anatomically to maize inflorescences not been discussed by any archaeobotanist, to my knowledge. Further, carbonization of macrospecimens can change size and shape, as can heating and other types of damage to starch grains. Thus, identifications based purely on size are not definitive. Ancient specimens identified by researchers as a particular cultivated species are not necessarily convincingly similar to modern ones in illustrations, and analysts' identifications are often hedged with qualifications that get 
lost in the secondary literature (e.g., Pagán-Jiménez, Rodriguez-Ramos, Reid, van den Bel, \& Hofman, 2015). Inferences on hypothetical fresh anatomy extrapolating from desiccated and presumptions about what trait forms ancient people might have selected are based upon the frailest grounds (e.g., Benz, 2001). Most are not illustrated or enumerated, and some are mere personal communications (Mora, 2003; Herrera et al., 1992; Schrimpff et al., 2005, pp. 32-35, and note 24). Such identifications are weak because they can't be checked and debated.

It's difficult for archaeobotanists to become familiar with all the large number of tropical forest natives and their phylogeny, so mistakes in identification are made, such as the assignment of a seed identified to a species of the myrtle family to the bean family. Researchers often assume that early-context specimens of taxa that people later cultivated must be cultivated plants, but they could simply collected plants or plants from background vegetation (e.g., Piperno \& Pearsall, 1998, p. 200). Many such taxa are common locally in early successional vegetation: Ipomoea in sunny terrain and Maranta in shadier terrain (Roosevelt, 1991, p. 24 on Ipomoea carnea). Unfortunately, most tropical lowland palms and flowering trees that are cultivated do not differ greatly morphologically from uncultivated examples, and most are not actually domesticated plants anyway (Clement, de Cristo-Araújo, Coppens D’Eeckenbrugge, Alves Pereira, \& Picanço-Rodrigues, 2010; Lorenzi, 2002). Humans manage them but they also exist dispersed in the forest without the need for human intervention. The cultivated Amazonian tree Brazil nut, for example, grows more easily when planted by humans or large rodents, its main dispersers, but it does grow without them. The role of humans in its Holocene dispersal is inferred from the taxon's comparatively low genetic diversity over its range compared to wild species (Shepard \& Ramirez, 2011). Another probable human artifact may be the frequent clustering of Brazil nut trees at sites with Black Indian soil, considered an indicator of permanent habitation.

DNA analysis of modern remains can help resolve the history of cultivation and dissemination of a plant (Bradley, 2006; Emshwiller, 2006), as well as the regional migrations of early people, but there are currently significant interpretive problems for using genetic patterns from DNA analysis of modern populations to infer the history and location of domestication of plants anciently. Claims that wild ancestors of cultigens such as manioc have been definitively identified in a region often lack a firm basis in comprehensive geographic sampling and DNA analysis (e. g., Olsen \& Schaal, 1999, 2006). Few studies have done adequate sampling for modern examples throughout the possible areas of origins (Perry, 2002b, p. 347), and there has been little work on the DNA associations of modern cultivars' characteristics, so the meaning of molecular comparisons remains opaque. When researchers do include maps of sampling site locations, these show that sampling was not comprehensive areally (e.g., Grant, Hatheway, Timothy, Cassalett, \& Roberts, 1963). Few genetic studies deal with the problem that cultivars can hybridize with "wild" or weedy species and thus alter the distribution patterns "in the wild". A further problem is that during the anthropocene humans may have changed the distribution of possible wild ancestors. Moreover, many factors including molecular mechanisms make time-telling by molecular clocks highly problematic (Emshwiller, 2006). As an example, the author of the widely cited figure of 9000 BP for the earliest maize cautioned not to rely on it (as pointed out by Langlie et al., 2014, p. 1607).

But the study of ancient DNA from both plants and humans is becoming more and more viable and valuable, due to improvements in technology of analysis and wider applications. Fortunately, it is not the case (contra van den Bel, 2015, p. 58) that human bones generally do not survive in neotropical climates, and many sub-fossil materials including some carbonized plants retain extractable DNA, which can be compared with DNA from other archaeological contexts and from modern populations. The DNA in subfossil materials at high latitude sites has allowed identification of numerous species to help reconstruct ancient late Pleistocene habitats (Willerslev et al., 2014). And molecular studies have shown that yams were domesticated independently in the different continents, including South America, Africa, and in several parts of southeast Asia (Malapa, Noyer, Marchand, \& Lebot (2006). Application of such methods to the lowlands could solve some important interpretive issues and greatly expand data on the distribution of species and cultivars over time and space.

Microfossils, unfortunately, cannot be dated directly individually to check their age. Even grouping enough of them to get a radiocarbon date does not yield definitive evidence of age. Dates on groupings of microfossils are imprecise for the same reason that groups of charcoals are, because the individual specimens aren't necessarily all the same age (Langlie et al., 2014). Though it's sometimes said that starch grains have been directly dated, what was actually dated was an unidentified carbonized mass that had a few identified starch grains in it (e.g., Piperno, 2011). Another problem with microfossils is that some starches, especially maize and manioc starch, but also now soybean, sorghum, and wheat starch, are widely used for sizing of the paper and cloth (Paper Academy, 2012) used to contain, label, and/or handle samples (e.g., Pagán-Jiménez, 2012, p. 82, 85). And cornstarch, the most common lubricant for lab gloves is abundantly dispersed in the air where they are used (Occupational 
Safety \& Health Administration [OSHA], 2005; U.S. Food and Drug Administration [USFDA], 1997). It's argued that extracting starch grains from dental calculus allows the avoidance of contamination (Barton \& Torrence, 2006; Mickleburgh \& Pagán-Jiménez, 2012), but that's only if the researchers follow strict field and lab hygiene.

A recent study of contamination in archaeology starch identification labs found widespread and sometimes abundant contamination with modern starches, raising serious doubt about the authenticity of starch grains claimed in the past to represent ancient plant presence (Crowther, et al., 2014). Maize, the most common starch identified archaeologically is also the most common lab contaminant. A large range of lab utensils and materials were found to be contaminated with modern starch grains, from pipettes and slides to cloth, paper, and plastic bags. The same study found that recommended tests for contamination did not reliably detect contamination and that routine cleaning procedures were not effective at eliminating the contaminants. By my observation, the procedures of hygiene, conservation, and provenience maintenance in many dating, archaeology, and botany labs do not protect materials from contamination and degradation. Objects are often scrubbed in tap water or, worse, river water and left in the hot sun to dry rapidly (causing deterioration and dust pick-up). Specimens are handled repeatedly with unwashed hands, separated from proveniences, enclosed in gelatin capsules that shatter and contaminate them, leaving them mixed with specimens of other provenance. In all these ways it's easy for individual specimens to be dislocated, making very rare finds unreliable bases for conclusions. The significance of the distributions of identified taxa in excavation strata are not usually evaluated statistically, and big conclusions are made based on only one or two microfossils (Bush et al., 1989). It's been recommended for future studies of microfossils that negative controls be analyzed along with the target samples (Crowther, et al., 2014), and I believe that samples should always be analyzed blinded. Past identifications have not, on the whole, used such controls.

\subsection{Quantifying Diet}

Beyond dating and identification, how to quantify the changing consumption levels of different foods through time? Different types of plant and animal parts are preserved in different quantities vis-à-vis those originally consumed, creating horrific barriers to reconstruction of diets. Actualistic studies comparing materials with their decay products can help, but they have shown that preservation is not very predictable thus far (Piperno \& Pearsall, 1998). Certainly, sandy, draughty soils are not good for microfossil and bone preservation but can be good for carbonized macroplants. Clayey soils are generally better for all types of remains but can be difficult to separate from the remains without damage. But how to figure out the degree of use of identified materials? Stable isotopic analysis of modern and ancient human and animal bones and plant remains sometimes can contribute to the evaluation of both biological community structure and diet in prehistory and today, helping to get around some of the difficulties. And combining the different methods and extracting different materials, along with provenience control, soil analysis, and exhaustive dating can also help with interpretive problems. Studying all phases of occupation, including recent and modern ones, also helps in the navigation of interpretive difficulties.

Before the florescence of archaeobotany, artifacts were the main evidence on subsistence, and they still are influential in researchers' interpretations. Unfortunately, by themselves, they usually don't give much information on specific foods and importance of cultivation. Contrary to earlier assumptions, some Archaic pottery cultures lack any evidence for agriculture, and some Archaic pottery seems used ceremonial purposes rather than for cooking (see section 3.2, Archaic horticulture?). Griddles, once parsed as evidence for manioc or maize, the main ethnographic staple plants in northern South America, are commonly used to bake cakes of both plants and any number of other plant foods as well, nowadays, including Brazil nuts. Rock slabs also serve the same purpose. Recently, flaked or ground stone "axes", both celts and waisted or notched axes, have been argued to be strong evidence for Archaic, or even Paleo, farming, as hoes (e.g., Schrimpff et al., 2005). But these tools need to be interpreted in both archaeological and ethnographic context. Flaked and ground stone axes and adzes are found in early Paleoindian sites in Amazonia but are interpreted as wood-working tools (see the next section). Foragers observed historically actively use digging tools to collect food that is not, however, cultivated (Hart, 1960). Furthermore, early ethnographic stone celts and waisted axes in museum collections from Amazonia, Orinoquia, and the Guianas are hafted as axes, not as hoes (e.g., de la Penha, Bruni, \& Papavero, 1986, p. 43, 250; Versteeg $\&$ Rostain, 1999), and Warao people of the Orinoco mouth often used adzes for chopping starch out of palm trunks (Heinen, 1988). It's also been pointed out that most of the early Colombian tools are too small to be axes or hoes and don't have the expected wear produced by experiments; so they have been reinterpreted as paring knives, instead (e.g., Santos Vecino, Monsalve, \& Correa Salas, 2015). It's not clear why pounding and cutting of game or fish are not considered also, as metal knives, choppers, and hammers of the size also are common butchering or meat-tenderizing tools in recent days. 
As can be seen from the following account, our methods and research results so far fall far short of the rigor and precision that could give a clear and substantive picture of the early history of agriculture in the northern lowlands of South America (Figure 1). However, it is possible to isolate some intriguing patterns in the prehistoric record.

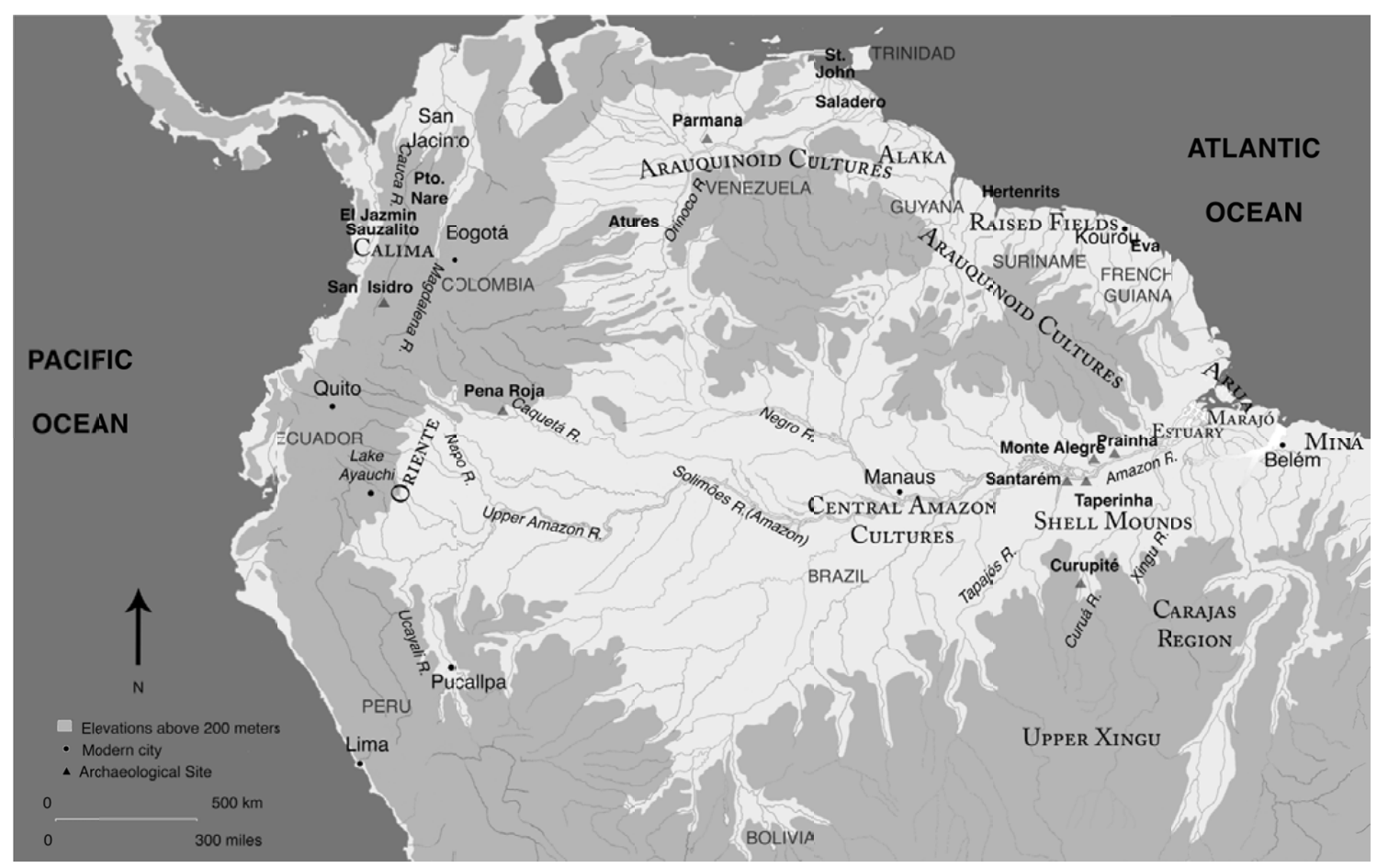

Figure 1. Map of northern South America and the Caribbean coasts with sites and features mentioned in the text (by L. Brown and A.C. Roosevelt)

\section{The Prehistoric Record}

\subsection{Paleoindian Farming? c. 11 000-10 000 BP}

Despite the Ice-Age savannaization hypothesis, all the cores from the Amazon mouth show forest in the basin in the late Pleistocene (Maslin, Ettwein, Boot, Bendle, \& Pancost, (2012). Thus, the earliest colonists likely encountered tropical forests, not grasslands. The arrival of Paleoindians in the tropical lowlands and Isthmian area about 11 000-10 000 years ago is heralded by the appearance of unusual disturbance indicators in sediment cores. In Panama, there are layers with significantly increased charcoal particles (Piperno et al., 1990). At the mouth of the Amazon there is an unprecedented peak in pollen from Cecropia, a disturbance indicator par excellence (Haberle, 1997). As yet few Paleoindian sites have been dated and studied archaeobotanically in the tropical lowlands, though, and none in the Orinoco and Caribbean coast, so we must look to the Brazilian Amazon and Caribbean-draining river valleys of Colombia for some scraps of evidence.

Several Paleoindian occupations with carbonized plant remains between 11000 and 10000 BP in age have been excavated. Caverna da Pedra Pintada in the sandstone hills of at Monte Alegre in the Brazilian Amazon was dated by assays on tree and palm fruits and wood charcoal and on burnt lithics and sediment, ranging from 11 000 to 10000 BP (>60 dates), and Painel do Pilão rockshelter, nearby, gave three dates on wood charcoal, at c. 11000 BP (Davis 2009, 2014; Roosevelt et al., 2009; Roosevelt et al., 1996; Roosevelt, Douglas, \& Brown, 2002). The stratigraphy and dates at Monte Alegre sites indicate a 5-phase continuous occupation from early to late Paleoindian times. The Paleos of this culture roamed far; closely related lithic tools also appear deep in the Guiana and Brazilian shields (Roosevelt et al., 2009). Only mid to late Paleoindian occupations have been found in tropical lowland Colombia (Aceituno, Loaiza, Delgado-Burbanoc, \& Barrientos, 2013; Aceituno \& Loaiza 2014; 2015; Dickau et al., 2015; Gnecco \& Mora, 1997; Lopez, 2008), a tectonically active upland landscape where sites could easily be eroded or covered up. San Isidro in the Cauca valley has terminal Pleistocene dates of c. $10000 \mathrm{BP}$ on tree and palm fruits and charcoal. La Palestina, San Juan Bedout, and Nare, in the Magdalena valley date between 10400 and $10230 \mathrm{BP}$ ( 8 dates on charcoal), but botanical remains from the sites have not 
yet been studied. In the Cauca drainage, the PIII0I-52 site had a date of 10260 BP, and El Jazmin and La Morena, dates of $10100 \mathrm{BP}$ (1 date each).

The predominantly low stable carbon isotope ratios of wood charcoal dated from all the Paleoindian sites reflect habitat communities structured as forests, not as savannas. And contrary to the theoretical premise that the tropical forest was too poor in edible wild plants and game to support hunter-gatherers (Bailey, Head, Jenike, Owen, Rechtman, \& Zechenter, 1989), the Paleoindians in the humid tropics intensively foraged a large number of both plant and animal foods. Palm and tree fruits and tree legumes are the most common kinds of carbonized plant foods in the tropical Paleo sites. Species of many of the identified taxa are cultivated near habitation sites in the tropical lowlands today, but few or none are considered domesticated plants (Goulding \& Smith, 2007; Lorenzi, 2002; Smith, Vásquez, \& Wust, 2007). Brazil nut (Bertholletia excelsa) was identified in the Brazilian cave site but was very rare. The sandy Brazilian soils did not preserve phytoliths or pollen, but the cave had thousands of pieces of carbonized seeds from many palm and tree genera now used for food or materials: Attalea, Astrocaryum, Hymenaea, Byrsonima, Saccoglottis, Talisia, Mouriri, and Vitex. Faunal remains recovered from the site, such as small fish, shellfish, turtles, and small land vertebrates, also are consistent with an intensification of a range of local resources.

None of the Colombian Paleo sites have produced faunal remains, perhaps an artifact of preservation conditions or of collection methods. San Isidro produced a large number of carbonized specimens identified to now-important cultivated food plants, including palms (Acrocomia), fruit trees avocado (Persea), which is now domesticated, a tree legume (Erythrina), whose pods and seeds are edible if processed to remove toxins, and several plants now used for materials (e.g., Lagenaria). Stone tools from the site produced starch grains identified to several genera of herbaceous herbs with starchy roots. Some of the grains are said to be either Xanthosoma, Ipomea, or Manihot, and some speculated to be Maranta (an arrowroot). Other grains were from a variety of grasses and legumes. Species, however, were not identified, most of the original identifications are now considered to be doubtful (Gnecco, 2000, pp. 67-69), and in any case all the possible genera and families occur in tropical forest successions today. A conclusion that the arrowroot species was cultivated, for example, was based on the supposition that plants of the family Marantaceae do not occur naturally in sub-Andean tropical forests (Piperno, 2011) however, they do occur (Cano, Young, Leon, \& Foster, 1995, p. 280). The avocado pits were thought to be cultigens at first, but archaeobotanists concluded that their size was not proof of cultivation on its own (Piperno \& Pearsall, 1998, p. 200). So, it's not the case that there's evidence that any of these plants were necessarily cultivated or under domestication there in the late Pleistocene. (That avocado pits had been carbonized at San Isidro, in addition to the palm fruits, has been thought a great mystery, because the fruit is eaten raw today (Schrimpff et al., 2005, p. 32). However, oily or woody fruit pits are commonly burned for charcoal in Amazonia, especially those of palms (e.g., Anderson, May \& Balick, 1991), but also those from other species.

These few Paleo occupations that have been studied are surprisingly sedentary, to judge by the extended seasons represented by their food plants and animals (Gnecco \& Mora, 1997; Roosevelt, 2000; Roosevelt et al., 1996), and at all the sites people appear to have disturbed and selectively altered their habitats. In the Brazilian cave, the continuing occupation created a black Indian soil, and anthropic effects on the forest around the site are suggested by the abundance of terra firme palm remains with less negative stable carbon isotope ratios than those of the carbonized wood of trees in the same site levels. In modern anthropic palm forests, instead of being dispersed in the shady forest understorey, the palms are grouped close together in clearings, where they are more productive of fruit, due to more sun exposure. Anthropic palm forests today can be a by-product of either seed discard or of human planting in prepared clearings (Anderson, 1988; Anderson et al., 1991; Politis, 2009).

The tool types from Paleo sites do not shed light on the issue of cultivation. The formal lithic tools from Pedra Pintada include stemmed, triangular point fragments, gravers, and small and large unifacial cutting tools such as adzes/limaces, all made by flaking. The point forms are reminiscent of modern harpoons and fish arrow points. Entire cutting tools of flaked stone were cached in the cave, whereas only broken points were left there. Whole points, however, are common finds at rapids in the interfluves, where migrating fish pass, however (Roosevelt et al., 2009). In San Isidro and other Colombian sites, also, whole cutting tools of ground or flaked stone, such as axes or adzes/limaces, were left behind with mostly broken flaked tools (Santos Vecino et al., 2015; Gnecco, 2000, pp. 51-56; Gnecco \& Mora, 1997). However, abundant, fine flaking debris at sites shows that people were making points but must have been taking them away from sites for use. The Magdalena sites in Colombia had stemmed triangular point fragments and the adze/limaces, as did Pedra Pintada, and the PIII0I-52 site in the Cauca had, a triangular, broad-stemmed point. Having points does not mean that hunting was important source of food in a site occupation, though, and the big-game hunter hypothesis does not work well for tropical forest 
Paleos. Despite all its point-making debris, Pedra Pintada had only 3 tiny bone fragments from vertebrates as large as a deer, among thousands of remains from plants, fish, and turtles. Other faunal specimens identified were shellfish, turtles, large rodents, and reptiles. The large and small unifacial cutting tools at that site would seem indicative of wood-working, as do the flaked or ground "axes" at San Isidro, whose edge-ground cobbles and grinding stones have been interpreted as plant processing tools. El Jasmin and La Morena both had small "axes", grinding stones, and flake tools, all interpreted as part of a plant-oriented industry, though use on faunal food would presumably also be a possibility.

These northern lowland Paleo sites have contributed to the recognition that plant food, especially palm fruit and tree legumes, was very important in the initial settlement of the continent, though without faunal remains at some sites, our knowledge of food economies as wholes is incomplete. Some of the identified plant taxa are planted nowadays, as mentioned in this section, but there is not yet any direct evidence that cultigens were planted at Paleo sites (contra Piperno, 2011). All of the taxa identified from carbonized macroplants are indigenous to the regions and have no morphological indicators to signal domestication. None of the identifications from plant microfossils are to species, so there is no systematic taxonomic data to help decide whether they are cultigens or not. That they were sometimes recovered from plant processing tools seems to show the plants in question were probably used for food but not whether they were planted. If not planted, then at least people were in the type of regular relationship with the plants that could in some species ultimately lead to changes that humans could have selected, moving them on the path to domestication.

\subsection{Archaic Horticulture? c. 10 000-5000 BP}

It is among sedentary Archaic societies, Sauer, Lathrap, and others predicted, that the origins of plant domestication in the tropical lowlands would be found. Among the centers of plant domestication indicated in South America, there are at least two hypothesized for the northern tropical lowlands: the northwest Amazon of Colombia and the northeast Amazon of Venezuela and the Guianas (Piperno \& Pearsall, 1998). The delineation of centers, however, is based on scattered and uneven evidence of possible ancestors and a rare archaeological finds from only a few regions and can be expected to change as more information comes in. The archaeobotanical findings are still sparse and inconsistent, due the novelty of these Archaic cultures, inconsistent application of the techniques for recovering and identifying plant specimens, and the incomplete information produced by the techniques. They nonetheless furnish some interesting patterns of evidence that shed light on the processes of human demographic and cultural change of which they were a part. As yet, though, there are no early Archaic sites in the Orinoco basin or Caribbean rivers or coasts with any secure evidence for planting or domestication.

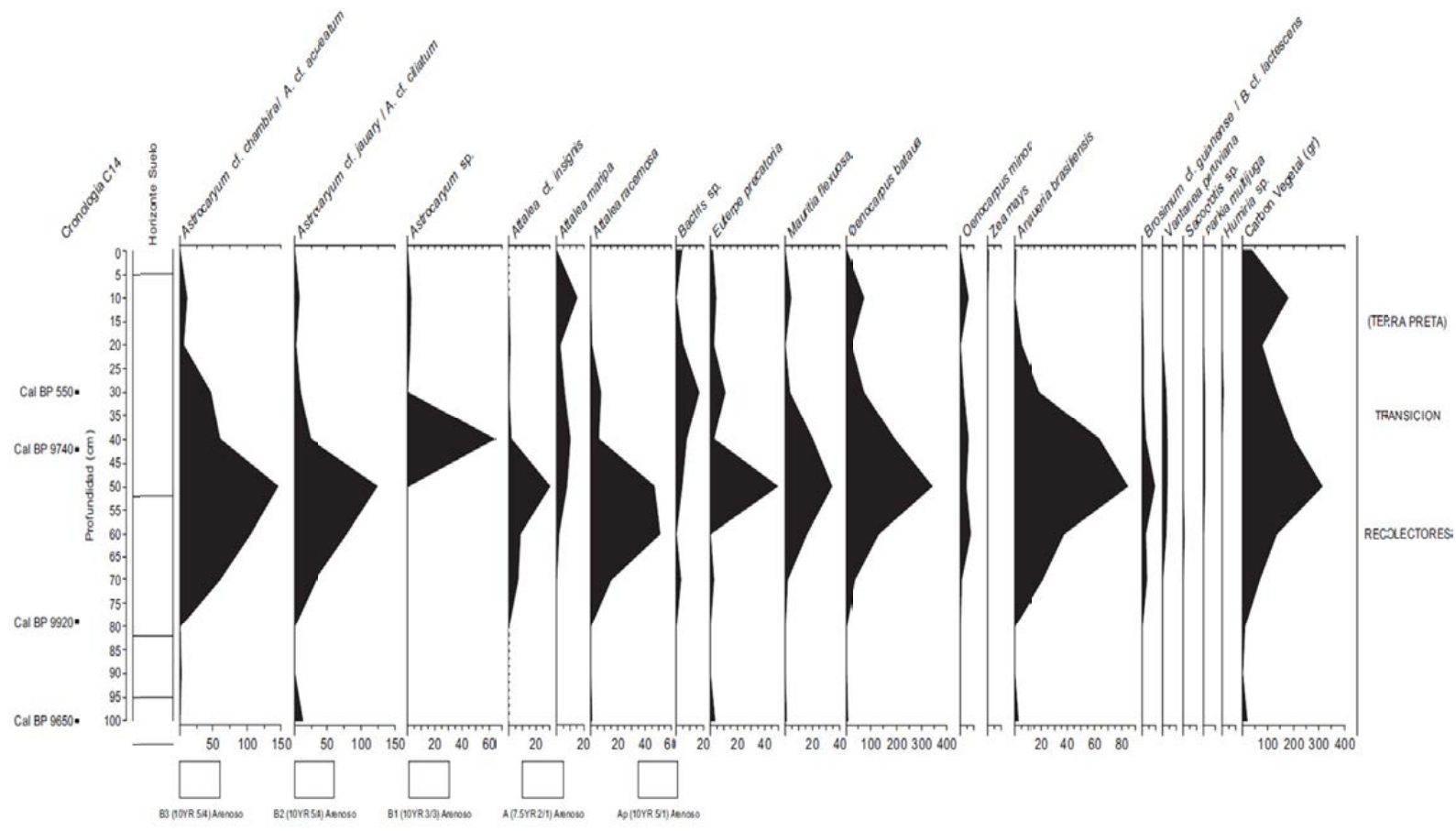

Figure 2. Pena Roja site, Holocene sequence of carbonized plant remains, Colombia (Morcote-Rios et al. 2014:46, Figure 14) 
The early Holocene component of Peña Roja site in the Colombian Amazon is dated between c. 9200-8000 BP (12 dates) on carbonized palm and tree fruit seeds. The site had large numbers of seeds of a total of 9 palm taxa (the genera Acrocomia, Astrocaryum, Attalea, Bactris, Euterpe, Mauritia, Oenocarpus) and several tropical fruits (genera including Beilschmiedia, Brosimum, Caryocar, Inga, Heliconia, Licania, Macoubea, Parkia, Oxandra, Saccoglottis, and Vantanea) (Mora, 2003; Morcote-Ríos \& Bernal, 2001; Morcote-Ríos, Aceituno, \& Sicard, 2014). These plants suggest intensive, broad-spectrum collection of the fruits of tropical forest palms and some trees, a system that persisted in many areas until the taking up of horticulture in late prehistory (Figure 2). Many are planted nowadays but are not domesticated. Cultivation at the site was hypothesized on the basis of as yet unpublished phytoliths identified to the Cucurbit family, to Calathea allouia (leren) of the Marantaceae, and to Lagenaria siceraria (bottle gourd). But there were marked disconformities in the poorly differentiated stratigraphy and pit intrusions from late prehistoric or modern strata down into preceramic strata that held the phytoliths (e.g., see the profile with an intrusive pit, Mora, 2003: 126, Figure 23). A stone grinder and a cutting tool from 60 to $70 \mathrm{~cm}$ depth, produced c. 56 starch grains identified to the Xanthosoma genus, but these are not claimed to be evidence for domestication, since several wild species are native to South America (Morcote-Ríos et al., 2014).

A pollen core from the Abeja archaeological site at Araracuara near Peña Roja in the Colombian Amazon is said to show maize and manioc cultivation in the late preceramic Tubaboniba phase, sometime before c. 4695-4330 BP (Mora, Herrera, Cavelier, \& Rodríquez, 1991, pp. 25-39). However, this ill-dated, patchily preserved component could not be excavated extensively so the result is highly preliminary. The authors found date reversals and clear evidence of the translocation of fines from upper strata to lower strata, obviously a hazard in the identification of rare microfossils that cannot be dated directly.

Numerous preceramic sites claimed by researchers to be evidence for early agriculture have been found during cultural resource management and research in the valleys of Colombian rivers that drain the tropical uplands into the Caribbean (Aceituno \& Castillo, 2005; Aceituno \& Loaiza, 2014, 2015; Bray et al., 1987; Castillo \& Aceituno, 2006; Dickau et al., 2015; Duncan et al., 2013; Gnecco \& Aceituno, 2006; Gnecco \& Mora, 1997; Herrera et al., 1992; Moore, 2014, pp. 130-179; Mora, 2003; Piperno, 2011; Santos Vecino et al., 2015; Schrimpff et al., 2005). They date between about 9000 to 5000 years ago, from soon after the end of the Paleoindian occupation until the beginning of the Formative occupation. The numerous disturbance indicators in the components at the sites are sometimes interpreted as evidence of slash and burn cultivation. However, the slight degree of disturbance indicated is not considered by some archaeobotanists to be secure evidence for slash and burn cultivation (Pearsall, 1995). Indeed, the early to mid-Holocene Colombian archaeological sites and pollen cores show clear dominance of mature dense tropical forest background vegetation. Also, numerous human skeletons recovered from one site show very negative stable carbon isotope ratios, with no detectable effect of carbon from open vegetation with $\mathrm{C}_{4}$ plants. Crude stemmed projectile points were found at two sites, but most lithics were flakes or unaltered stones used for grinding. Many sites had flaked or polished "axes" that the researchers interpret as hoes for cultivation. However, at c. $10-12 \mathrm{~cm}$ these are small for cultivation tools; however, they could be for fine wood-working or peeling and chopping vegetable foods or processing faunal foods.

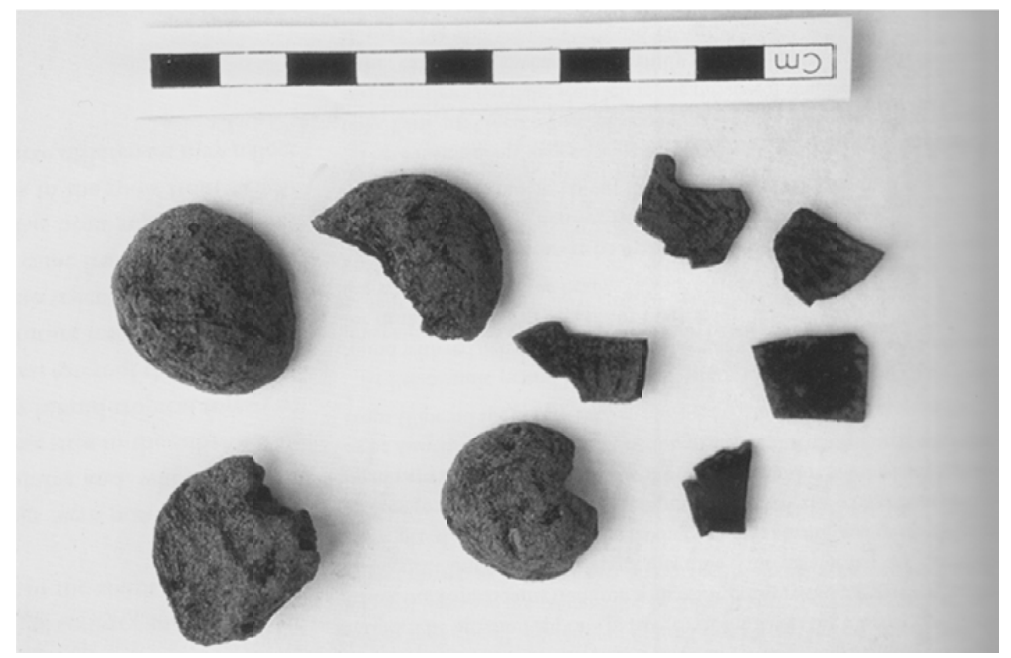

Figure 3. Sauzalito site, carbonized avocado seeds, Colombia (Schrimpff et al. 1991:33, Figure 1.4) 
There were abundant carbonized palm seed fragments and carbonized tree fruits at several of the sites but none firmly identifiable as macroplant cultigens. Genera of tree fruits include Annona and avocado (Persea) (Figure 3 ), both of which are today highly valued food plants that have important cultivated varieties as well as wild forms in northern South America. Some researchers feel that microfossils prove cultivation of bottle gourd, avocado, maize, amaranth, arrowroot, South American taro, yam, beans, and manioc are cultigens at those sites by 7000 to 9000 BP (Dickau et al., 2015; Piperno, 2011). Most identifications are based on starch grains from the surfaces and pores of "axes" or grinding stones or from pollen in sediments in excavation levels or pollen cores. However, the microplant finds from sites and cores are equivocal in both age and cultural context. Microfossil numbers are low or not given, and some macroplant specimens have widely divergent identifications: palm or avocado, in one case (Herrera et al., 1992), Rubus (Rosaceae) or Mora (Moraceae) in another (Dikau et al., 2015). Tentative identifications or ones from materials from insecure stratigraphic context are hardly definitive.

All of the plant identifications except maize are to plants available in the environment, and maize is identified only by very rare microfossils. The hypothesized maize consists of microfossils from excavated strata or swamp cores. The rare microfossils in strata could be any age, given the normal roots, burrows, and the translocation of clays in tropical forest soils. Specifically, the finds have problematic contexts: shallow deposits, amorphous, or strongly disturbed stratigraphy, obvious bioturbation, undulating strata crosscut by artificial levels, combination of materials of different ages, reversed dates, Formative dates, modern dates, or clearly old-carbon dates in the sequence, and/or singly-occurring microspecimens, and more. And most of the sampled levels they come from have few or no dates, and most dates are on unidentified charcoal or on soil samples. These problems make it unclear whether the pollen, phytoliths, or starch grains identified are from Archaic or Formative contexts.

The Archaic sequence of the Orinoco has yet to be investigated actively, though there has been speculation about it (Sanjoa \& Vargas, 2006). The few known sites don't give any evidence for cultivation but do document the early use of palm fruits for food. At the Atures Rapids near Puerto Ayacucho in the Orinoco, several sites produced carbonized palm endocarps, tentatively identified to a common palm (Oenocarpus bataua), but no faunal remains. For example, Provincial, a c. 9000 BP (two radiocarbon dates) site about $80-100 \mathrm{~cm}$ below the surface had what the excavator calls nondescript, crude stone tools: lithic flakes, a flake scraper, a core, a nutting stone, a hammerstone, fragment of a ground stone axe, and a polished hematite fragment (Barse, 1990; 2003). Organic remains included unidentified wood charcoal and the carbonized palm seeds. The possible palm species identified is found both wild and cultivated in the northern lowlands today but is not considered domesticated. The only other possible link to cultivation, the ground stone axe, is as likely to have been used for wood chopping, as discussed in section 3.1 on the Paleoindians.

\subsection{Archaic Complex Cultures}

Over and above the Archaic cultures discussed in section 3.2, continuing work on early prehistoric sequences in various parts of the tropical lowlands of South America and the Caribbean and Brazilian coasts has uncovered several examples of complex Archaic cultures. These cultures had diverse economies of intensive foraging on wild staples, such as fish and shellfish, palm and tree fruits, shrubs, roots, and/or seeds (Gaspar, DeBlasis, Fish, S., \& Fish, P., 2008; Mora, et al., 1991; Imazio da Silveira \& Schaan, 2005; Oyuela-Caycedo \& Bonzani, 2005; Roosevelt, 1995; Roosevelt, Housley, Imazio da Silveira, Maranca, \& Johnson, 1991). Some of the cultures appear to be relatively sedentary, and others, more mobile. The features considered complex include special ceremonial mounds and precincts, funerary facilities, domestic structures, and/or special art and crafts, including decorated pottery, jewelry, ground stone effigies and axes, and ritual objects, such as drug-taking equipment.

The complex Archaic cultures in the vicinity of major lowland rivers and estuaries differ from those in smaller river basins in having pottery. Opposite the Paleoindian sites of Pedra Pintada and Painel do Pilão at Monte Alegre in the Lower Amazon near Santarem is a complex Archaic site, Taperinha, dating to c. 7000-6000 BP (13 dates, of which one was TL on pottery). This monumental, $>6 \mathrm{~m}$-tall shell mound with both domestic and ceremonial features around it had thick sand-tempered pottery with a rare incised rim sherds, some small grinding slabs, a few bone tools and ornaments, shell scrapers, and many fire-cracked rocks. Subsistence appears to have been focused on fish, several species of freshwater shellfish bivalves, and turtles. Carbonized plant remains were rare in the site; its sandy and/or shelly sediments have not produced identifiable phytoliths or starch grains; and the pollen from two swamps cored not far downriver produced plenty of disturbance indicators but no possible cultigens (Piperno \& Pearsall, 1998: 230-232). The diet seems to have been quite adequate, apparently, for the teeth of a child of c. 9 years buried there were free of any pathologies. A Paituna-phase shell-midden in the middle levels of Pedra Pintada cave, occupied between 7500 and 5000 years ago BP (7 dates, one of which was TL on pottery), produced similar pottery and food remains. At the mouth of the Amazon, the 6500-5500 BP year-old Mina and Alaka monumental shell mound sites of the pottery Archaic also have 
subsistence emphasizing fish and shellfish, including varied univalves and bivalves. Carbonized plant remains also are rare in them).

On the lower Magdalena River not far from the Caribbean coast of Colombia, the c. 6000-4600-year old (13 dates) sites of San Jacinto have remarkable, rare, elaborately-decorated pottery food service wares with incised and modeled zoomorphic decoration. Features within the sites include earth ovens, fire-pits, abundant fire-cracked rock, and stones for grinding, mashing, and nut-cracking. Subsistence is thought to have been based primarily on mush made by grinding gathered seeds or mashing roots and secondarily on large univalve and bivalve shellfish. But, as at Taperinha, no pollen was recovered, though one soil sample from a cooking pit yielded phytoliths of unidentified $\mathrm{C}_{3}$ grasses and of the arrowroot family (Marantaceae), though the number of specimens is not given. Flotation showed carbonized plants to be very rare around the cooking facilities, though, and the only common ones were shrubs of the Malvaceae family not known to be food sources today. The many weed taxa identified and the local provenance of the site's lithic materials suggest site occupations of as long as six months in the seasonally humid tropical environment. The very negative stable isotope ratios accord with a heavily wooded landscape, however.

On the southwest coast of Trinidad, the shell midden of St. John, dated between 6900 and 5000 BP on shell, yielded a small number of securely identified starch grains including some possible cultigens (Pagán-Jiménez et al., 2015). The excavator at the site, Basil Reid, had taken great pains to conserve the artifacts for analysis, making the results possibly more definitive than usual. But all radiocarbon dates in one unit, 3 , were in reverse order, with the latest date, $5080 \mathrm{BP}$, equivalent to an early Formative date on the mainland, in the base level, and the earliest date, $6710 \mathrm{BP}$, at the surface, a range of almost 2000 years in the wrong direction. This is unequivocal evidence of a stratigraphic reversal that went undetected by the artificial excavation levels. Of the firm identifications from strata with consistent dating, there were 29 grains of Zea, identified as maize with the expectation that there was no wild maize ancestor in the region. All the other identifications were tentative or from the reversed strata. What with the small number of grains overall, the problem of maize contamination in labs, and the date reversals, it's not clear whether taxa other than maize were present and were cultigens and whether any of the starch grains analyzed are Archaic or later in date. Although the site is represented as a single component preceramic Archaic site by the authors, it has a number of ceramic-age and historic occupations including mid- and late-prehistoric camps and villages, a colonial cane field, a provision garden, and a house site (Boomert, Faber-Morse \& Rouse, 2013). Further excavations and dating could clarify the situation.

All these sites, then, do not seem to make up strong evidence for early cultivation of maize or any other domesticated plant during the Archaic. Non-domesticated taxa identified could have been either collected or cultivated. So it still appears to be the case that strong evidence for maize cultivation is confined to the early Formative (see the next section). If, however, maize cultivation can one day be firmly dated to the Archaic, then it would seem to be the earliest demonstrable cultigen in the sequences, and the implication would be that the concept of cultivation was introduced from the outside. Strangely, this is not an implication recognized by researchers who both claim very early presence of maize at c. 9000 or $10000 \mathrm{BP}$ and interpret their sequences as evidence of indigenous development of plant domestication.

Except for the universal shift in the Archaic to relatively crude lithic tools compared to the finely flaked Paleo lithics, the general Archaic culture pattern so far is one of strong regional diversity in culture and subsistence (Oyuela-Caycedo 1996). Unfortunately, most of the more sedentary Archaic sites, where the process of domestication might have been facilitated, according to the Sauer/Lathrap way of thinking, had few plants remains compared to the less sedentary ones. Away from rich estuaries and floodplains, more mobile societies thought likely centers of domestication, don't have recognizable cultigens with firm identifications, either. But Peña Roja, which had abundant carbonized palm seeds, lies in the hypothesized zone where peach palm might have been domesticated (Morcote-Ríos \& Bernal, 2001), so it is a place where more intensive research on sites with plant remains would be valuable. And, given the very incomplete Archaic record, intensive search for new sites in different kinds of local habitats would seem in order.

\subsection{Formative Horticulture c. 5000-1500 BP}

Investigations at many Formative sites have yielded possible cultigens. The doubts about them, not always acknowledged, include inadequate study collections to confirm taxonomic IDs and very small numbers of most of the securely identified taxa. When very few specimens of a taxon have been identified, any doubts about the identification loom large and hamper solid conclusions. And when stratigraphy is disturbed or excavation is by artificial levels, mixture of sediment of different ages is to be expected and with it mixture of specimens of different ages. Unfortunately, the quantitative relationship of microfossils to subsistence economy is even more 
uncertain than that of macrofossils, because of the dating problem, and few sites have the kinds of studies of human remains that permit quantification of diet components. Nonetheless, there is a high degree of similarity in the complex of possible cultigens of Formative sites. Among the few taxa that recur at different sites, the most common is maize.

SITIO SALADERO, BAJO ORINOCO, VENEZUELA FEBRERO 2013

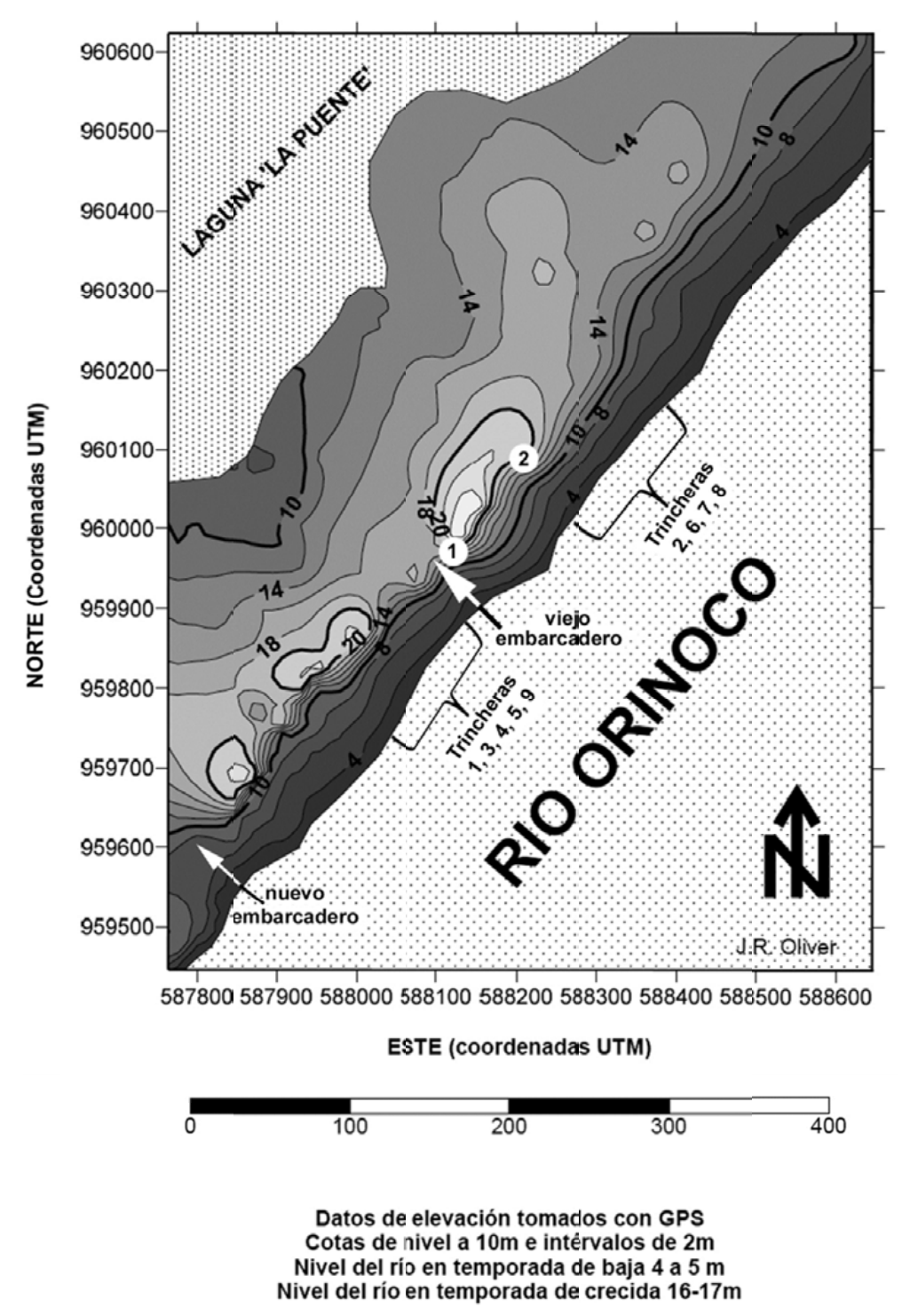

Figure 4. Saladero site map, Venezuela (Oliver 2014: 99, Figure 1)

\subsubsection{Formative Ceramic Cultures}

The best known cultures of the Formative of the Orinoco, Caribbean Colombia, and the Guianas, belong to the Saladoid-Barrancoid Horizon defined originally by Cruxent and Rouse, from materials in the lower levels of the Saladero site in the lower Orinoco (3000-2500 BP 7 dates) (Figure 4) and from La Gruta, Ronquin, and the lower levels of Corozal in the middle Orinoco (c. 3000-1400 BP) (Cruxent \& Rouse, 1958-1959; Oliver, 2014; Roosevelt, 1980, 1997; Rouse \& Cruxent, 1963). Related cultures outside the Orinoco include several phases defined in Trinidad (Boomert, et al., 2013; Fewkes, 1914) and Kaurikreek (4200-3750 BP) and Wonotobo Falls (1800-2000 BP) in Surinam (Boomert, 2000; Rostain, 2008 a and b; Versteeg, 2008). The cultural horizon was expansive in nature, spreading slowly but widely through the lowlands through mechanisms thought to have 
included trade and alliance, rather than mass migrations (Boomert, et al., 2013). Examples of styles are found from the Caribbean coast all the way to the Upper Xingu and from the mouth of the Amazon all the way to the upper Amazon. These Formative societies are difficult to model as complex chiefdoms with central paramount leadership and defined social hierarchies, but they do manifest significant investment in ceremonialism, mound architecture, funerary rites, and fine artworks with complex iconography. No sites have been wide-area-excavated in the Orinoco, to recover ceremonial foci with whole vessels or structure patterns, so this pattern of complexity is seen more clearly in research results on the Formative cultures of Trinidad and Tobago and Island of St. Eustatius (Boomert, 2000; Versteeg, 1998; Fewkes, 1914), and at sites in the Greater Antilles (Siegel, 2010). However, some late Formative sites in both the Orinoco and the Guianas do have clear examples of earth construction: mounds and early raised fields in the western Orinoco and in the Guianas, and mounds in the middle Orinoco.

The elaborate iconography of the styles of the horizon are mostly found in the characteristic sand- or crushed-rock-tempered pottery, though some regions have their own distinctive tempering methods, such as shell, sponge spicules, and possibly tree bark ash. The most common Saladoid-Barrancoid decorated vessel is the effigy bowl with zoomorphic adornos on the rim or handle and grooved zoomorphic decoration in a band on the inside or outside; rare effigy bottles depict animals with human some features. Such images have been interpreted as representing the animism still important in indigenous cultures of the Amazon and Orinoco today (Boomert, et al., 2013; Roosevelt, 1980, 1997). Many decorated vessels have soot on the base, from cooking, and several vessels from Saladero appear to have been sealed with bitumen, judging from the infinite radiocarbon dates on the material. All the styles have griddles, which could have been for cooking cakes of manioc, manioc, maize, palm starch, many other foods, and/or combinations of foods, as Greater Amazonian people do today (Heinen, 1988; Roosevelt, 1980). Some marginal sites of the horizon have the shallow grooved incision, rim forms, and characteristic temper but lack the elaborate zoomorphic imagery.

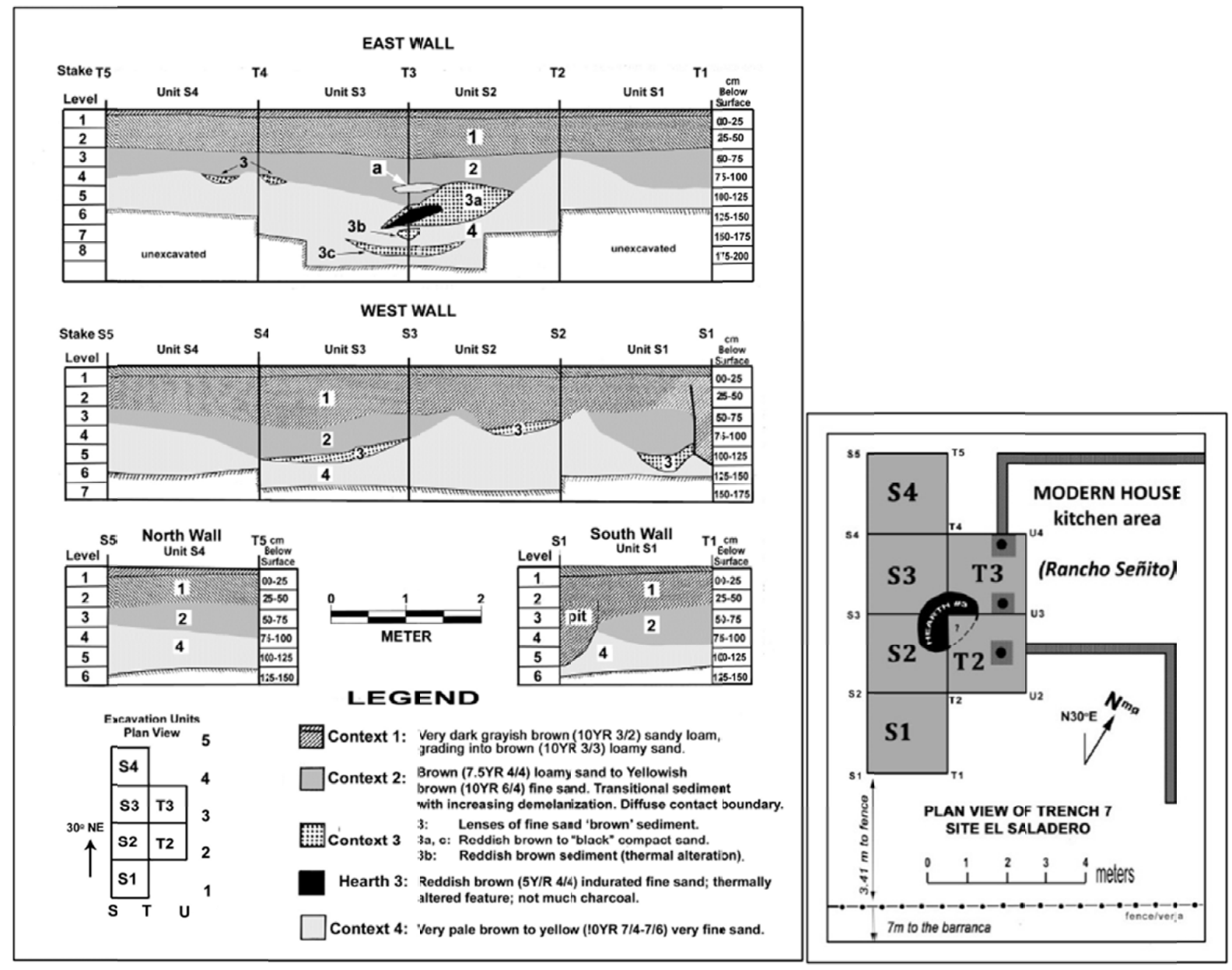

Figure 5. Saladero stratigraphy and plan drawings (units S1 and S4 from Trench 7, Oliver 2014:103, Fig. 5) 


\subsubsection{Dating the Formative}

There is uncertainty about the history of the local styles and use of plants because the sandy Orinoco levee sites have significant disturbances, with proof from AMS dating that later materials have descended into earlier layers. Careful restudy of the site of Saladero by Oliver shows that the early Formative layers had been pierced with pits from later layers and abut the kitchen of a modern house (Oliver, 2014) (Figure 5). The site is capped with late prehistoric deposits related to the regional pottery horizon characterized by intensive maize use (discussed in the next section) (Cruxent \& Rouse, 1958, pp. 213-237). In the middle Orinoco, some early Formative levels at Corozal have intrusions of maize kernels from late Formative levels, proven by direct AMS radiocarbon dates on the kernels, and other sites there also show mixture between prehistoric levels and intrusion of late prehistoric and post-conquest materials. Too-old dates from sites in both areas seem related to petroleum products used by ancient people for fuel or sealant, and the sites' loose, sandy soils allow recent materials to descend in the many burrows and root holes. Lignite from the site under the modern settlement of Parmana gave infinite radiocarbon dates, confirming the hypothesized identification as low grade coal. At Saladero, all the dates on black sherd coatings that yielded microfossils were infinite or too old dates (Table 1), following the pattern discussed in Section 2.3. Sites in other regions, such as Eva in French Guiana, also have sandy sediment and numerous inconsistent dates.

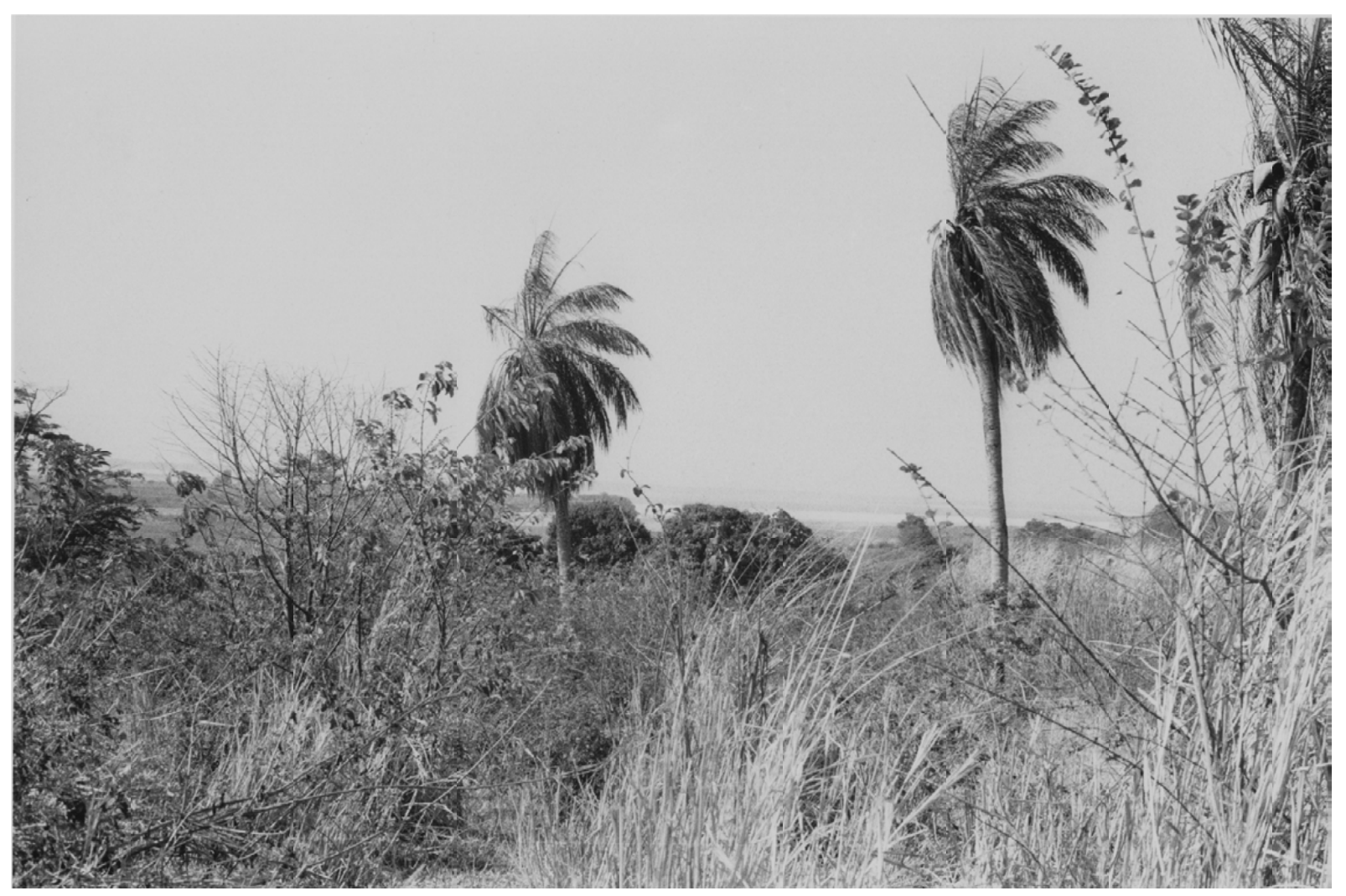

Figure 6. Corozal site, Venezuela (Roosevelt 1997: Plate 2, top)

The palms are corozo (Acrocomia aculeata), a species still often cultivated in northern South America. The current local economy relies on ranching. Ranchers clear and burn vegetation to create pasture but often protect useful trees 
Table 1. *Saladero AMS radiocarbon dates and starch grain identifications from the carbonaceous coating on sherds (Oliver 2014: 104, Table. 5)

\begin{tabular}{|c|c|c|c|c|c|c|c|}
\hline OxA-\# & $\begin{array}{l}\text { No. de } \\
\text { Laboratorio } \\
\text { (Pagán); } \\
\text { del Museo } \\
\text { Peabody }\end{array}$ & $\begin{array}{l}\text { Trinchera } \\
\text { No. } \\
\text { Sección: } \\
\text { nivel } \\
\text { profundidad }\end{array}$ & $\begin{array}{l}\text { Descripción de la } \\
\text { cerámica** }^{*}\end{array}$ & $\begin{array}{l}\text { Identificación de los } \\
\text { almidones- } \\
\text { J. Pagán Jiménez }\end{array}$ & $\begin{array}{l}\text { Años } \\
\text { Radio-carbono } \\
\text { a.P. }\end{array}$ & $\begin{array}{l}\text { Calibración } \\
2 \sigma(95.4 \%) \\
\text { a.C. }\end{array}$ & $\Delta 13 C$ \\
\hline 28062 & $\begin{array}{l}\# 12-28 \\
\text { ANT.218113 }\end{array}$ & $\begin{array}{l}\text { Trinchera-7 } \\
\text { S3: nivel } 2 \\
25-50 \mathrm{~cm}\end{array}$ & $\begin{array}{l}\text { BAR-3 } \\
\text { panza con botón } \\
\text { modelado-inciso } \\
\text { (cauxí) }\end{array}$ & $\begin{array}{l}\text { Zea mays; } \\
\text { Leguminosae(?) }\end{array}$ & $27430 \pm 270$ a.P. & $\begin{array}{l}30417-29230 \\
\text { a.C. }\end{array}$ & -27.8 \\
\hline 28063 & $\begin{array}{l}\# 12-28 \\
\text { ANT.218113 }\end{array}$ & $\begin{array}{l}\text { Trinchera-7 } \\
\text { S3: nivel } 2 \\
25-50 \mathrm{~cm}\end{array}$ & $\begin{array}{l}\text { BAR-3 } \\
\text { panza con botón } \\
\text { modelado-inciso } \\
\text { (cauxí) }\end{array}$ & $\begin{array}{l}\text { Zea mays; } \\
\text { Leguminosae(?) }\end{array}$ & $27330 \pm 160$ a.P. & $\begin{array}{l}29846-29251 \\
\text { a.C. }\end{array}$ & -27.5 \\
\hline 28064 & $\begin{array}{l}\# 12-26 a \text { \& } \\
\# 12-26 b\end{array}$ & $\begin{array}{l}\text { Trichera-7 } \\
\text { S3: nivel } 4 \\
75-100 \mathrm{~cm}\end{array}$ & $\begin{array}{l}\text { BAR-3 } \\
\text { fragmento de panza de una } \\
\text { olla con } \\
\text { modelado-inciso-punteado } \\
\text { (cauxí) }\end{array}$ & $\begin{array}{l}\text { (a) Zea mays (?) } \\
\text { Marantacea } \\
\text { silvestre; } \\
\text { (b) Manihot cf. } \\
\text { esculenta; Zea mays; } \\
\text { Capsicum spp.; } \\
\text { Leguminosae }\end{array}$ & $\begin{array}{l}29400 \pm 220 \\
\text { a.P. }\end{array}$ & $\begin{array}{l}32686-31465 \\
\text { a.C. }\end{array}$ & -27.7 \\
\hline 28065 & $\begin{array}{l}\# 12-27 \mathrm{a} \& \\
\# 12-27 \mathrm{~b} \\
\text { ANT.218686 }\end{array}$ & $\begin{array}{l}\text { Trinchera-7 } \\
\text { T3: nivel } 5 \\
100-125 \mathrm{~cm}\end{array}$ & $\begin{array}{l}\text { BAR-2 } \\
\text { fragmento de borde recto y } \\
\text { hombro de una olla globular, } \\
\text { sin decorar }\end{array}$ & $\begin{array}{l}\text { (a) Zea mays, } \\
\text { fermentada(?); } \\
\text { Leguminosae } \\
\text { silvestre; cf. } \\
\text { Capsicum sp.; } \\
\text { cf. Manihot } \\
\text { esculenta; } \\
\text { (b) Zea mays }\end{array}$ & $\begin{array}{l}29960 \pm 250 \\
\text { a.P. }\end{array}$ & $\begin{array}{l}33140-32075 \\
\text { a.C. }\end{array}$ & -27.9 \\
\hline 28066 & $\# 12-25$ & $\begin{array}{l}\text { Trinchera-7 } \\
\text { S3: nivel } 7 \\
150-175 \mathrm{~cm}\end{array}$ & $\begin{array}{l}\text { SAL } \\
\text { fragmento de budare(?) sin } \\
\text { decoración }\end{array}$ & $\begin{array}{l}\text { Zea mays; } \\
\text { cf. Manihot } \\
\text { esculenta; posible } \\
\text { ñame (Dioscorea } \\
\text { spp.) }\end{array}$ & $32080 \pm 320$ a.P. & $\begin{array}{l}35596-33569 \\
\text { a.C. }\end{array}$ & -27.9 \\
\hline (ORAU-33406) & $\begin{array}{l}\# 12-23 \\
\text { ANT.218233 }\end{array}$ & $\begin{array}{l}\text { Trinchera-7 } \\
\text { S3: nivel } 6 \\
125-150 \mathrm{~cm}\end{array}$ & $\begin{array}{l}\text { SAL } \\
\text { fragmento de budare, con } \\
\text { decoración incisa } \\
\text { (sin costra de carbón) }\end{array}$ & Zea mays & sin fechar & sin fechar & $\mathrm{x}$ \\
\hline (ORAU-33402) & $\begin{array}{l}\# 12-24 \\
\text { ANT.215712 }\end{array}$ & $\begin{array}{l}\text { Trinchera } 1 \\
\text { B2: nivel } 6 \\
125-150 \mathrm{~cm}\end{array}$ & $\begin{array}{l}\text { BAR-1 } \\
\text { fragmento de budare, sin } \\
\text { decoración } \\
\text { (sin costra de carbón) }\end{array}$ & $\begin{array}{l}\text { Zea mays, } \\
\text { Capsicum sp. }\end{array}$ & sin fechar & sin fechar & $\mathrm{x}$ \\
\hline
\end{tabular}

* The samples of starch grains were taken from the crust of carbonized food on the inside of the shred and/or from the interstices of the inside surface. All the ressulting dates are contaminated with old carbon. Oxa-28062 and -28063 are from the same sample (ANT.218113).

** SAL $=$ Saladero style; BAR-1 $=$ Barrancas style; $\mathbf{B A R - 2}=$ Los Barrancos style; BAR-3= Guarguapo style. 

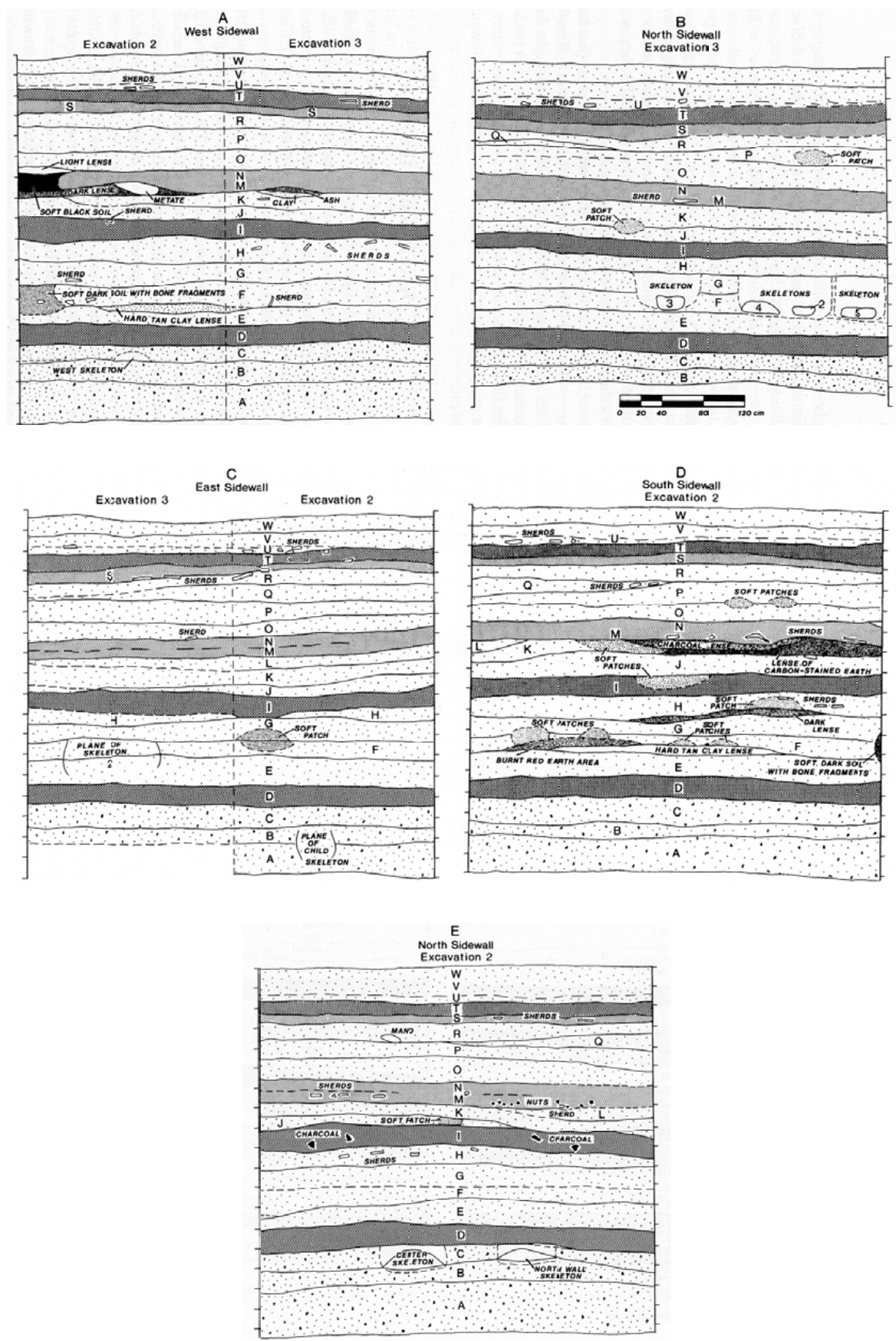

Figure 7. Corozal site, stratigraphic profiles of the excavations

A. North sidewall, Excavation 2.

B. West and north sidewalls.

C. East and south sidewalls (Roosevelt 1997: 42-43, Fig. 6).

In both the middle and lower Orinoco, the numerous dates that have been run for Saladoid/Barrancoid related culture are so varied that both long and short chronologies have been proposed: one that starts the Formative at about $4500 \mathrm{BP}$ and ends it about $1600 \mathrm{BP}$, another that places the Formative between 1000 and $2000 \mathrm{BP}$ (Barse, 2000; Boomert, 2000; Gassón, 2002). Most of the dates, however, fall before the common era, which the short chronology does not accommodate. The AMS dates on wood charcoal pieces identified to short-lived shrub and tree taxa fall between 3080 and 2501 BP (4 dates) (Oliver, 2014: 101, Table 4). At Caverna da Pedra Pintada in Monte Alegre, an Amazonian Saladoid-related culture gave dates between 3700 and 3300 BP (8 dates) on 
carbonized plant wood and seeds, a human cranium, and a human tooth (Roosevelt, 2000, p. 482, Table 15-3). These dates fit the long chronology. Dates for related cultures in the Guianas also fit the long chronology better than the short one. Most of the Formative pottery style dates there fall between 4000 and 1500 years ago. In Surinam, the Saladoid Kaurikreek site gave dates at about 4000 BP, while the Barranoid Wonotobo Falls site gave dates between 2000 and 1800 BP (Boomert, 1983; Rostain, 2008a: 284; Versteeg, 1978, p. 2008). In French Guiana, at the juncture of the Guiana shield and the coastal plain, Eva, a site with thin-walled, sand-tempered pottery and fine petaloid celts found by bulldozer was dated between 5100 and 3700 BP with 3 "accepted" dates (Pagán-Jiménez et al., 2015; van den Bel, 2015, pp. 125-166). However, the 3 dates are a minority among numerous contradictory radiocarbon and TL dates thousands of years apart from each other, so its age is not yet clearly established. Although published as a pottery Archaic site of the Alaka phase, the pottery's sharply tapered rims, sometimes thin walls, and variable sand temper pastes (van den Bel, 2015, p. 160, Figure 4.20) resemble those in Formative pottery (Boomert, et al., 2013, p. 72, Figures 39-1, 98, Figures 39-7; 58-6; Roosevelt, 1997 : Figures 16E, 20) but do not resemble those of classic Alaka pottery, which has thick walls, mostly round rims, and shell temper (Evans \& Meggers, 1960, p. 55-59). Unlike Alaka-phase sites, Eva is not a shell mound, either, and its dates place it in early Formative times, not expected Archaic times. For all those reasons, it is included here as an early Formative culture, not Archaic.

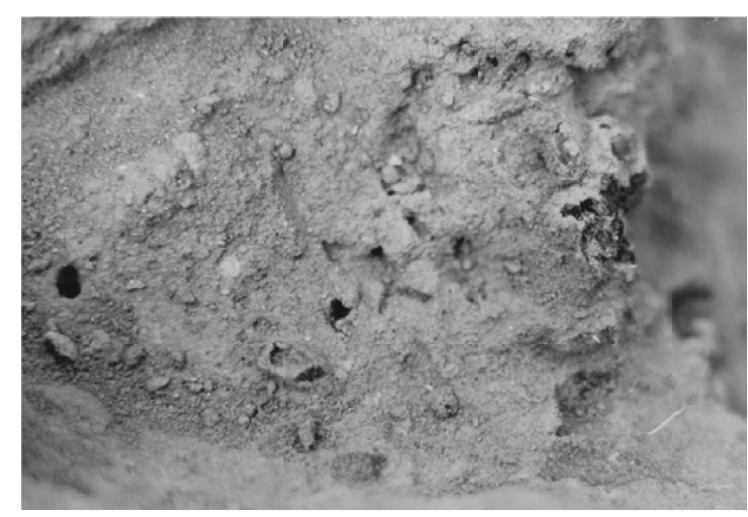

Figure 8A. Corozal site carbonized maize from the excavations. (Photos by W. Galinat and A.C. Roosevelt (Roosevelt 1980: Fig. 79, above; Fig. 81, top) and C. Guadagno)

Carbonized kernels and cobs in place during excavation, hearth feature, Excavation 3, Level 5, 54-65cm depths, Camoruco 3 phase, Provenience \#63 (Roosevelt 1980: 237, Figure 78).

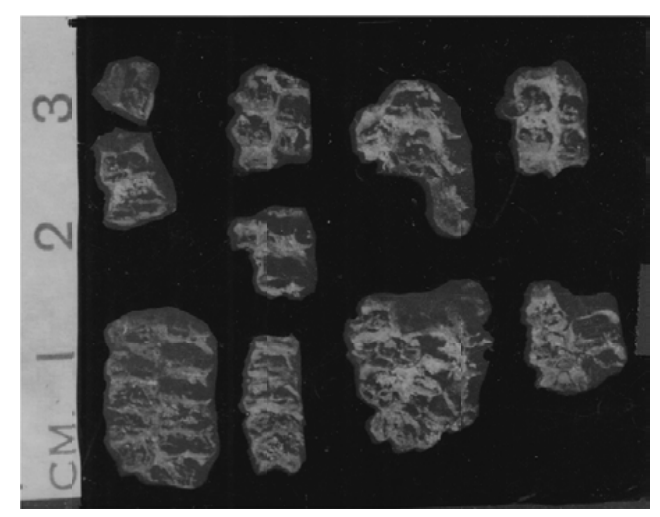

Figure 8B. Corozal site carbonized maize from the excavations. (Photos by W. Galinat and A.C.

Roosevelt (Roosevelt 1980: Fig. 79, above; Fig. 81, top) and C. Guadagno)

Carbonized cob fragments, Excavation 2, Level 7, Camoruco 2 phase, Provenience \#48.

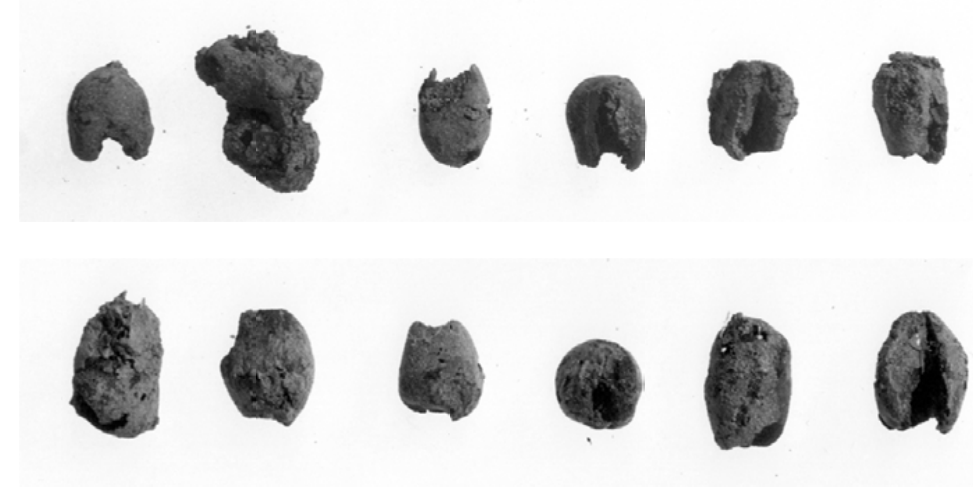

Figure 8C. Corozal site carbonized maize from the excavations. (Photos by W. Galinat and A.C. Roosevelt (Roosevelt 1980: Fig. 79, above; Fig. 81, top) and C. Guadagno)

Carbonized kernels, Excavation 3, Level 6, Camoruco 3 phase, Provenience \#25. Size range 9 to $11 \mathrm{~mm}$. 


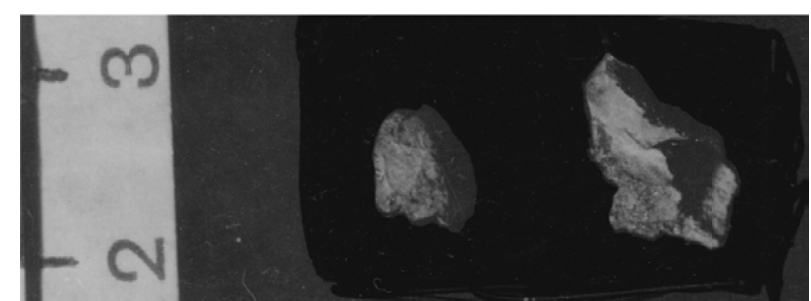

Figure 8D1. Corozal site carbonized maize from the excavations. (Photos by W. Galinat and A.C. Roosevelt (Roosevelt 1980: Fig. 79, above; Fig. 81, top) and C. Guadagno)

Carbonized kernels and cob fragments from Corozal phase levels, Excavation 2. Corozal 3 phase, Level 12, Provenience \#10.

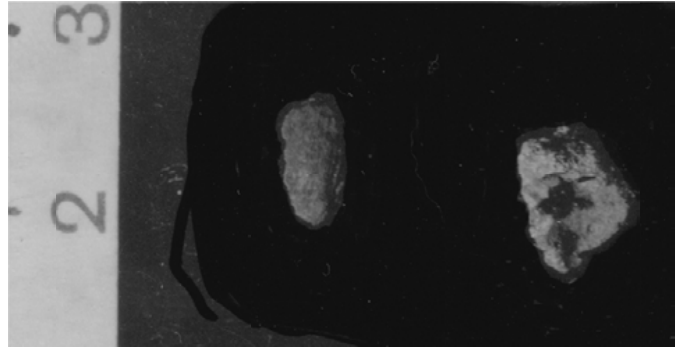

Figure 8D2. Corozal site carbonized maize from the excavations. (Photos by W. Galinat and A.C. Roosevelt (Roosevelt 1980: Fig. 79, above; Fig. 81, top) and C. Guadagno)

Carbonized kernels and cob fragments from Corozal phase levels, Excavation 2. Corozal 2 phase, Level 15, Provenience \#29

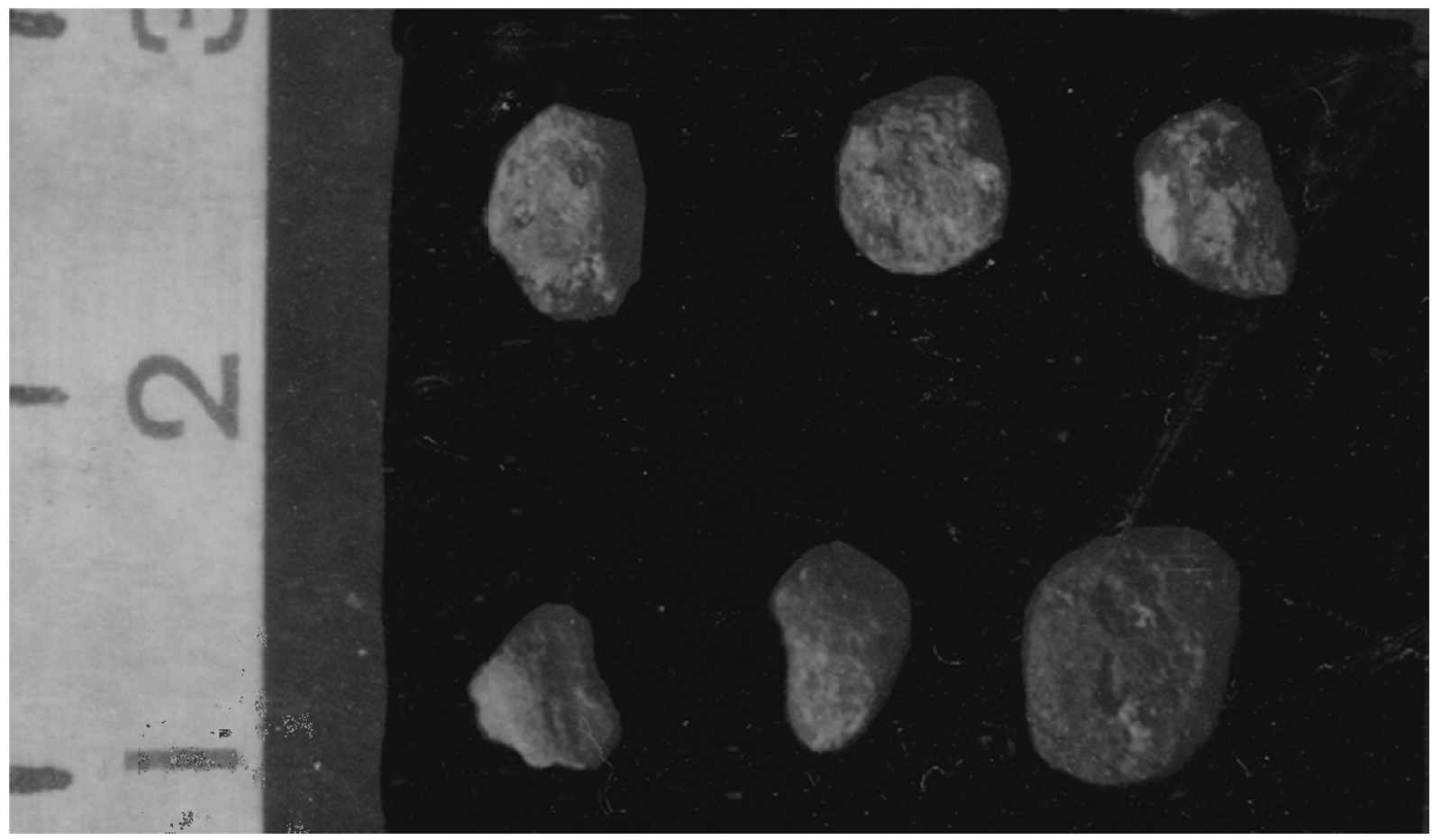

Figure 8D3. Corozal site carbonized maize from the excavations. (Photos by W. Galinat and A.C. Roosevelt (Roosevelt 1980: Fig. 79, above; Fig. 81, top) and C. Guadagno)

Carbonized kernels and cob fragments from Corozal phase levels, Excavation 2. Corozal 1 phase, Level 18, Provenience \# 27.

\subsubsection{Formative Food Remains}

Food remains have been collected from sites by a variety of methods, not always specified. In the middle Orinoco sites, we collected all visible archaeobotanical and faunal materials by hand, by soil flotation, and by total fine-mesh dry-screening of all soil. The analysis of food remains from the Formative levels (the Corozal phase) in the stratigraphy at the Corozal site (Figures 6,7, and 8D2 to 8D4, Table 2) yielded sporadic small, hard kernels of maize and numerous fishbones. As mentioned in section 3.4.2, the AMS dates on some of this corn had later Formative dates than the charcoal with which they were associated. Among the carbonized maize specimens were forms resembling those of the modern Venezuelan race Pollo (Galinat, personal communication, 1992). Pollo is a hard-kernel semi-pop, short-cob race now grown in the northern Andes (elevation range c. 1300-2400 m a.s.1.) (Grant et al., 1963, p. 4, 30-32). This low-yielding race is not resistant to the fungi that afflict 
maize and is not now grown in the lowlands north of the Orinoco (Grant et al., 1963, pp. 30-32). Thus, it's unlikely to have been a local staple and could have been produced elsewhere and traded into the middle Orinoco in small amounts. Stable isotope analysis of four human skeletons from Corozal-phase levels showed little or no effect of consumption of a $\mathrm{C}_{4}$ plant such as maize (Figures 10A and 10B, and Table 3) (Roosevelt, Krueger, Sullivan, nd; van der Merwe, Roosevelt, \& Vogel, 1981). The sandy-textured sediments of these levels did not contain preserved phytoliths or pollen, but sediment samples are curated and sherds and lithics with residues not washed, so these could be studied for microfossils and organic substances in the future. At the Saladero site, curated materials were analyzed for microfossils (Oliver, 2014: 104, Table 5, and 108-109). Starch analysis conclusively identified 29 maize grains and 3 manioc grains but only tentatively identified a small amount of sweet potato, arrowroot, Xanthosoma, legumes, and chili peppers. Though it seems clear the relatively abundant and ubiquitous maize remains must be Formative, we don't know where exactly in the cultural sequence they belong, because of the extensive mixture between levels and lack of any direct dates on cultigens.

Table 2. Corozal, Excavation 2, Distribution of carbonized maize specimens (Roosevelt 1980: 238-242, Table 20. Feature and level subdivisions are combined in the table.)

\begin{tabular}{llllll}
\hline Excavation & Strata & Approximate & Phases & Provenience \# & \#Specimens \\
\hline levels & & depths in cm & & & $>1 / 2$ kernel \\
\hline 1 & W,V & $0-12$ & Postcontact & 49 & 0 \\
2 & V,U,T & $25-45$ & Camoruco 3 & 32 & 23 \\
3 & S & $45-60$ & Camoruco 3 & 34 & 110 \\
4 & R & $60-77$ & Camoruco 3 & 80,612 & 25 \\
5 & Q,P,O & $77-95$ & Camoruco 2/3 & $12,393,490$ & 57 \\
6 & Q,P,O & $95-112$ & Camoruco 2 & 60 & 62 \\
7 & N,M & $112-138$ & Camoruco 2 & 48 & 49 \\
8 & L,K,J & $138-143$ & Camoruco 2 & $4,28,380$ & 11 \\
9 & K,J,I & $153-167$ & Camoruco 1 & 43 & 15 \\
10 & I & $167-185$ & Camoruco 1 & 35 & 8 \\
11 & H \& feature & $185-210$ & Corozal 3 Camoruco1 & 47 & 3 \\
12 & G & $210-230$ & Corozal 3 & 10,36 & 1 \\
13 & F & $230-250$ & Corozal 3 & 3,26 & 2 \\
14 & E & $250-275$ & Corozal 2 & 2 & 0 \\
15 & D & $275-295$ & Corozal 2 & 7,29 & 0 \\
16 & D,C \& feature & $295-305$ & Corozal 1 & $37,42,62,293,542$ & 0 \\
17 & C & $305-310$ & Corozal 1 & 45 & 0 \\
18 & B & $310-320$ & Corozal 1 & 27,545 & 0 \\
19 & A & $3210-340$ & Corozal 1 & 54 & 0 \\
20 & A & $340-375$ & Corozal 1 & 40 & 0 \\
21 & A & $375-400$ & Sterile & & \\
22 & A & $400-425$ & Sterile & & \\
\hline
\end{tabular}

At late Formative mounds in Surinam, manioc microfossils were recovered (Versteeg, 2008), and the early Formative Eva-2 site in French Guiana, mentioned in section 3.4.2, had three stones with grinding wear from which 6 starch grains of Zea, 2 of Zamia, and 1 of sweet potato, were firmly identified (Pagán-Jiménez et al., 2015 , p. 237, Table 2; van den Bel, 2015, pp. 157-158). The tools, however, were handled and washed before analysis, the site's dates showed extensive mixing, so the provenance is not certain, and the numbers of specimens and identifications differ in the different publications. At the Peña Roja site in the northwest Amazon in Colombia, some maize and manioc microfossils and fruit remains of Avocado and Annona genera are reported for early Formative levels (c. 5000-3000 BP) but not enumerated or dated directly (Mora et al., 1991). In the lower Amazon at Caverna da Pedra Pintada, the directly dated human cranium and tooth from skeletons buried with early Formative pottery gave $\mathrm{C}_{3}$, not $\mathrm{C}_{4}$ plant diet results, showing no effect of maize consumption in those individuals (Roosevelt, 2000, p. 482, Table 15.3). The few Formative individuals from the Amazon and middle Orinoco show a pattern of robust good health, lacking the enamel hypoplasias and caries of some late prehistoric Andean and Mesoamerican populations heavily reliant on starchy food (Storey, 1992; Whittington \& Reed, 2006). The Corozal-phase skeletons have rugged frames and crania like some Saladoid populations in the Antilles (Drew, 2009). 
Many of the sites in the Columbian uplands whose rivers drain to the Caribbean have firm evidence of maize microfossils by the early Formative, along with sparse examples identified to the local plants that could be either background or cultivated (Aceituno \& Loaiza, 2014, 2015; Dickau et al., 2015).

If we can rely on occurrence of microfossils as well as macroplant specimens from secure contexts, a pattern seen widely during the Formative is the presence of a cultigen for long periods without their conversion to staple foods. Maize, for example, is definitely documented in the lowlands of Amazonia and the Orinoco by reasonable numbers of microfossils (50-100) and a few dated macro-specimens from the mid to late Formative period, c. 3000 to $1500 \mathrm{BP}$, but maize is not shown by stable isotope analysis to be a staple food until the period between 500-1500 BP. Thus, the Formatives definitely were cultivating maize in the Orinoco and northern Amazon, but a number of other foods were more important in the diet. Thus, it is not the case, as I proposed earlier (Roosevelt, 1980), that the arrival of maize was soon followed by its adoption as a staple in the sense of furnishing a large majority of calories. That process took many hundreds of years. Until c. 1500 BP, other plants must have furnished most of the vegetal food. Manioc and other root, tuber, or corm-bearing plants, bean varieties, and tree fruits, are likely ones, though there is as yet no way to measure their proportions of food consumed (but see the discussion of the use of nitrogen isotopes to study legume/game/seafood versus other $\mathrm{C}_{3}$ plants and maize in Amazonian diets, Roosevelt, 1989 and Antillean diets, Pestle \& Colvard 2012).

\subsection{Intensive Agriculture in the Orinoco and Guiana Coasts c. 500-1500 BP}

\subsubsection{Late Prehistoric Ceramic Cultures}

Only during late prehistory, when many northern tropical lowland areas became influenced by the Arauquinoid style series of the so-called Incised and Punctate cultural horizon (Boomert, 2000; Lathrap, 1970; Rouse \& Cruxent, 1963), is there firm isotopic and botanical evidence for the adoption of a fully domesticated plant as a dietary staple, i.e., the main source of food. The plant in question was indeed maize, and the agricultural systems in which it became the main staple were the floodplain and wetland raised field cultivation systems of the coastal and riverine lowlands of South America. Based on both archaeological and ethnohistoric evidence, the adoption of maize as a staple was the joint achievement of a series of culturally-related, wealthy, populous, and warlike polities that formed along the floodplains of the larger rivers of Caribbean and Orinocan Colombia, the Venezuelan Orinoco, and the Guianas' coasts during late prehistory.

Regions whose study inform on these patterns include the western Orinoco plains of Colombia and Venezuela (Garson, 1980; Gassón, 1998; Spencer \& Redmond, 1992, 2014; Spencer, Redmond, \& Rinaldi, 1994; Zucchi \& Denevan, 1979), the middle Orinoco of Venezuela (Perry, 2004; Roosevelt, 1980; 1997; van der Merwe et al., 1981; Smith \& Roosevelt, 1985), the lower Orinoco in Venezuela (Oliver, 2014), and the coastal plains of the Guianas (Boomert, 1980; 1987; 2000; Iriarte et al., 2010; McKey et al., 2010; Rostain, 2008ab, 2013 a and b; Versteeg, 2008). [Arauguinoid relatives and also a variety of local cultures have been identified in western, northern, and eastern Venezuela (Gassón, 2002; Navarrete, 2008) and Caribbean coast of Columbia (Oyuela-Caycedo, 2008), but their subsistence has not yet been investigated comprehensively.]

\subsubsection{Evidence for Maize as a Staple}

Maize's status as a staple in late prehistory is indicated in several ways: the comparative high frequency of its pollen compared to other food plants' pollen in the relevant levels of western Orinoco sites (Spencer \& Redmond, 2014: 844-848), its greater ubiquity compared to other food plants' starch grains in the later levels of Saladero in the lower Orinoco (Oliver, 2014: Table 5), the hundreds of carbonized maize specimens and highly $\mathrm{C}_{4}$ influenced stable carbon isotope ratios of late prehistoric human skeletons and food residues (Figures 8A, 8B, 8C, 8D1, 10C, and Tables 2 and 3) (Roosevelt, 1980; 1997), the hundreds of starch grains (Perry, 2004) in relevant levels at sites in the middle Orinoco, and the ubiquity of maize phytoliths in the raised fields on the Guianas' coasts (Iriarte et al., 2010). Maize history is not well known in the Amazon proper, but at Lake Ayauchi in the Ecuadorian Amazon, maize phytoliths became very abundant between 2400 and 800 BP. (Piperno, 1990); and $\mathrm{C}_{4}$ range stable carbon isotope ratios start to appear in the bones of some individuals between about AD 500 and 1500 on Marajo Island in the Brazilian Amazon and at Lake Yarinacocha in the Peruvian Amazon (Roosevelt, 1989; 2000, pp. 480-486). 
Table 3. Corozal prehistoric skeletons' collangen stable carbon isotope ratios (Van der Merwe et al, 1981: 537, Table 2; Geochron Laboratories report, 11/14/1995. The result on apatite for provenience \#293 was $-10.20 / 00$, an indication that despite the dominance of C-4 plants on collagen values Camoruco people's food included some C-3 plants or animals subsisting mostly on C-3 plants.)

\begin{tabular}{|c|c|c|c|c|c|c|c|}
\hline Lab \# & Excavation & Level/stratum & Depths/cm & Provenience \# & Skeleton & Cultural phase & $\mathrm{d} 13 \mathrm{C}(\mathrm{o} / \mathrm{oo})$ \\
\hline UCT-259 & 3 & $18 \mathrm{G}, \mathrm{F}$ & $225-250$ & 56 & Adult 2 & Camoruco 1 & -9.7 \\
\hline UCT-258 & 3 & $18-19 \mathrm{G}, \mathrm{F}$ & $240-252$ & $6,147,149,203$ & Adult 3 & Camoruco 1 & -10.5 \\
\hline GX-18087 & 3 & $22 \mathrm{~F}, \mathrm{E}$ & $235-255$ & 50 & Adult 4 & Camoruco 1 & -10.5 \\
\hline UCT-286 & 3 & $18-22 \mathrm{~F}, \mathrm{E}$ & $235-255$ & 50 & Adult 4 & Camoruco 1 & -10.8 \\
\hline GX-18084 & 2 & $15 \mathrm{D}$ & $285 / 290-305$ & 644 & Adult north & Corozal 1 & -19.2 \\
\hline GX-18086 & 3 & $25 \mathrm{D}, \mathrm{C}$ & $295-300$ & $46 a, 148$ & Adult 2 & Corozal 1 & -19.3 \\
\hline GX-18085 & 3 & $26 \mathrm{~A}, \mathrm{~B}$ & $300-325$ & 148 & Adult 3 & Corozal 1 & -20.9 \\
\hline GX-18081 & 2 & $16 \mathrm{C}$ & $280-310$ & 293 & Adult center & Corozal 1 & -25.0 \\
\hline UCT-260 & 2 & $16 \mathrm{C}$ & $280-310$ & 293 & Adult center & Corozal 1 & -26.1 \\
\hline GX-18080 & 2 & 18-19 C,B,A & $310-340 *$ & 545 & Child west & Corozal 1 & -20.5 \\
\hline UCT-287 & 2 & 18-19 C,B,A & $310-340$ & 545 & Child west & Corozal 1 & -25.8 \\
\hline
\end{tabular}

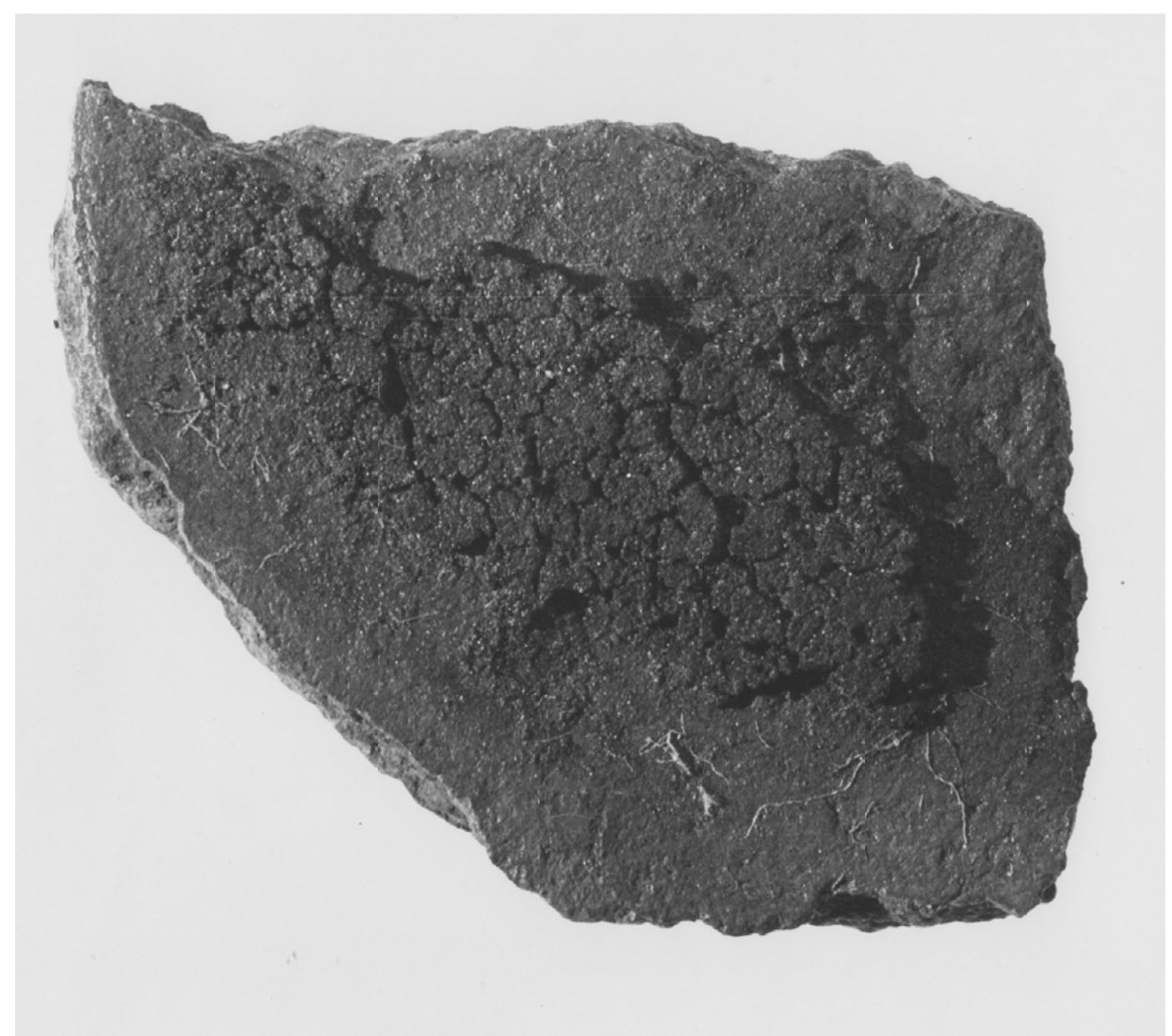

Figure 9. Ronquin site Camoruco phase sherd with carbonized crust, Provenience \#205-1) (Roosevelt 1980: 242, Figure 81 top)

The Ronquin sherd crust could not be analyzed isotopically for stable carbon isotope ratios because it had been solidified with PVA glue in the field. Crusts on four sherds from Corozal were analyzed (Roosevelt 1997:

202-206). Three indicated a C-4 plant such as maize: Exc. 2 Level 15, Provenience \#7 and \#29: 12.8o/oo; Exc. 2 Level 9, Provenience \#43: 15.4o/oo; Exc. 2 Level 7, Provenience \#48: 12.9o/oo; and the fourth indicated a C-3 plant food: Exc. 2 Level 2, Provenience \#32: 21.3o/oo. 


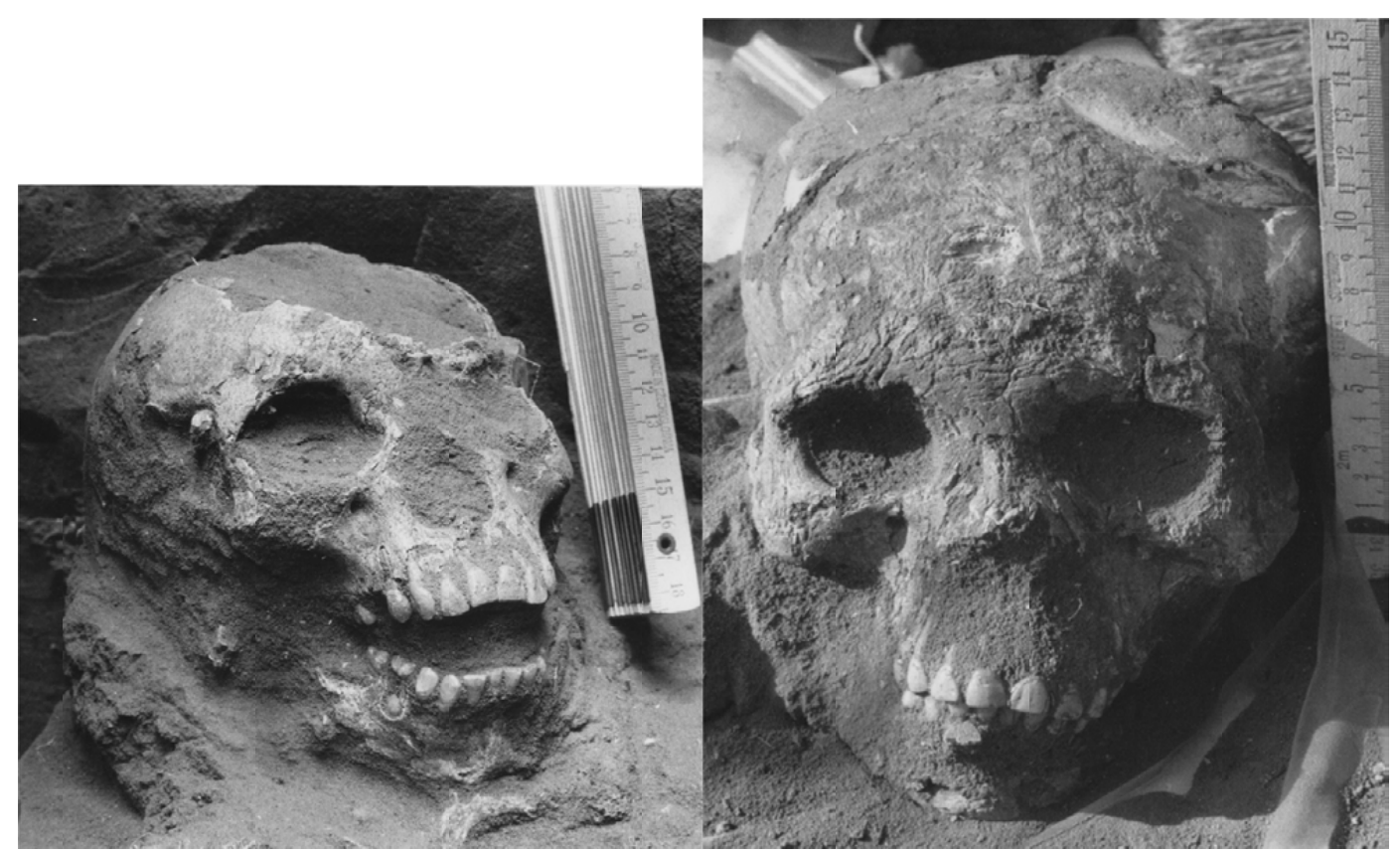

Figure 10A. Corozal site prehistoric skeletons

Skull from adult in the center of Excavation 2, Corozal 1 phase. (Roosevelt 1980: 245, Fig. 82, right)
Figure 10B. Corozal site prehistoric skeletons

Skull from child in northeast corner of Excavation 2, Corozal 1 phase

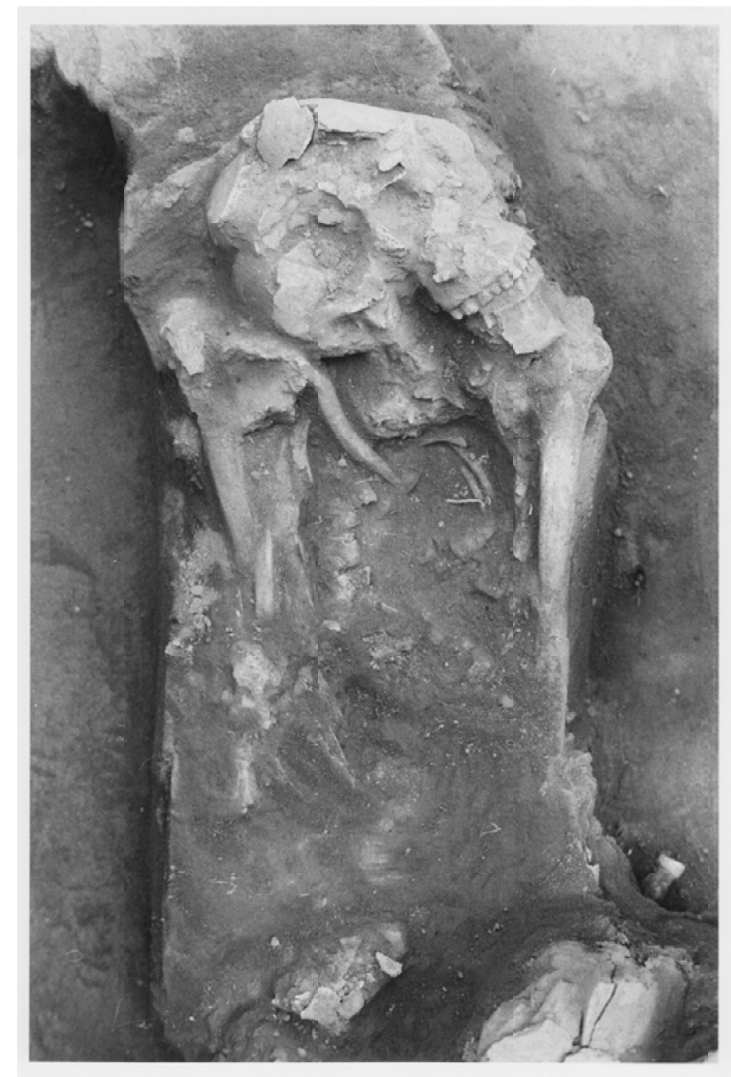

Figure 10C. Corozal site prehistoric skeletons

Skull from adult 2, northeast corner of Excavation 3, Camoruco 1 phase. (Roosevelt 1997: Plate 5). (The burial pits of the early Camoruco skeletons were dug down into late Corozal strata.) 
The timing of maize's brief reign in lowland South America seems correlated with appearances of maize races, population growth, and regional political organization in the particular habitats of river floodplains and wetlands. I had hypothesized that maize could have become the most important food on floodplain soils of the tropical lowlands as populations grew in later prehistory (Roosevelt, 1980). Indeed the evidence for a dominance of maize over other foods is contemporary with the late prehistoric rise in population density and political complexity. However, the apparent long lag between the arrival of maize cultivars and the staple cultivation of maize locally suggests that that the simple availability of the maize species could not have been not the root cause of population growth. A better model might be one of mutually reinforcing social, political, demographic, economic, and agronomic processes. The history and geography of the development and dissemination of particular maize cultivars, especially the larger, more productive and tropically adapted ones, may have been more involved in the timing of those processes than the species' mere presence.

The races of maize used locally as staples in northern South America in the mid 20th century are more like each other than like races in other areas and are considered locally developed varieties (Grant et al., 1963). Because of the epistemological problems mentioned earlier in this article, collecting has not been comprehensive, and the timing of the appearance of different maize varieties in tropical lowland areas is not well-established. However, in the few lowland regions where we have some sequence information, there is a clear change through time to more productive, disease-resistant maize races. So, for example, in the middle Orinoco, most of the few kernels of the earliest maize macrospecimens recovered, from the Formative Corozal phase, have morphological similarities with a lower-yielding modern highland race ill-adapted to lowland conditions (see section on the Formative). In contrast, many of the hundreds of specimens of maize kernels and/or cobs from the later prehistoric Arauquinoid Camoruco phase (Figures 8B, 8C, and 8D1 and Table 2) (Roosevelt, 1980, pp. 233-249, 1997, pp. 13-15, 57-66) resemble the northern South American lowland and Antillean variety Chandelle, which has larger, flatter flinty kernels with dented or soft-capped tips on a long, flexible, tapering cob (Grant et al., 1963, pp. 59-61). Chandelle and related lowland races are known from areas with both Carib and Arawakan speakers north of the Orinoco along the Caribbean coasts of Colombia and Venezuela and in the Antilles. While the Pollo race found in Corozal Formative levels is a northern Andean "primitive" highland race with hypothesized resemblance to some forms used by the highland Maya, Chandelle, resistant to fungal diseases that afflict maize, is considered a race of northern lowland origin, probably developed in Venezuela (elevation range c. 30-1000 m a.s.l). It is hypothesized by maize researchers, cited above, to have been taken to the Antilles in prehistoric times, where it survives in use in eastern Cuba, Haiti, Dominican Republic, and Trinidad. In other middle Orinoco sites of the period, maize is common among starch grains, $>75$ at one site (Perry, 2004). In the western Orinoco, in the early Gavan complex, equivalent to late Corozal and early Camoruco, few carbonized specimens were recovered, so races are not yet defined. The associated maize pollen is smaller than modern pollen there (Spencer \& Redmond 2014, pp. 844-848), possibly indicating a less productive variety than those used there now.

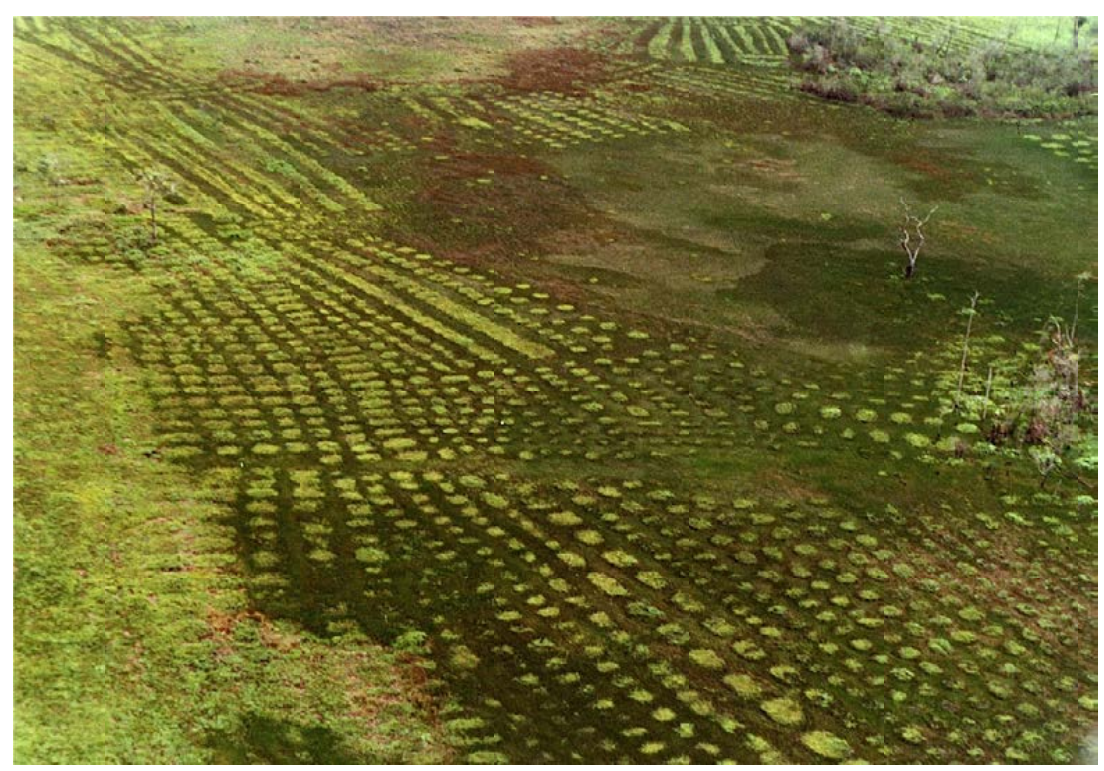

Figure 11. Air view of prehistoric raised field system near Diamant site, Karouabo, east of Kourou, French Guiana (Rostain 2013b: 35) 


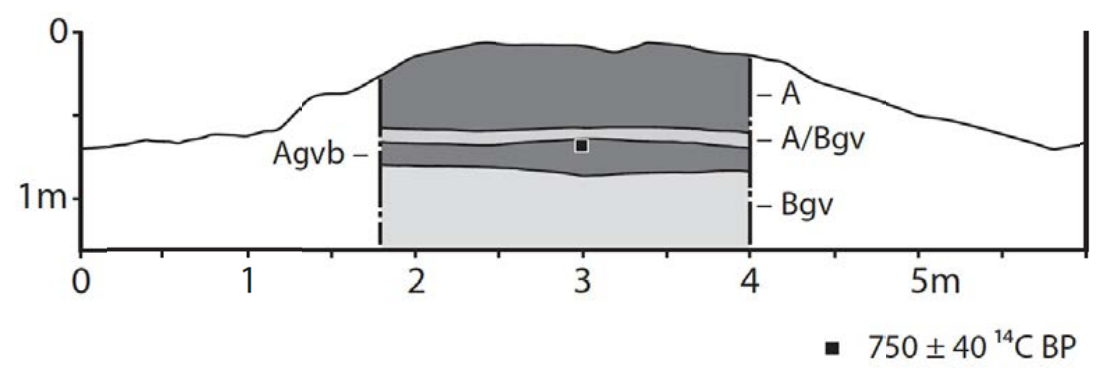

Figure 12. Schematic stratigraphic profile of radiocarbon-dated raised field, Bois Diable, Mound 1, French Guiana (McKey et al. 2010: 7825, Figure 2)
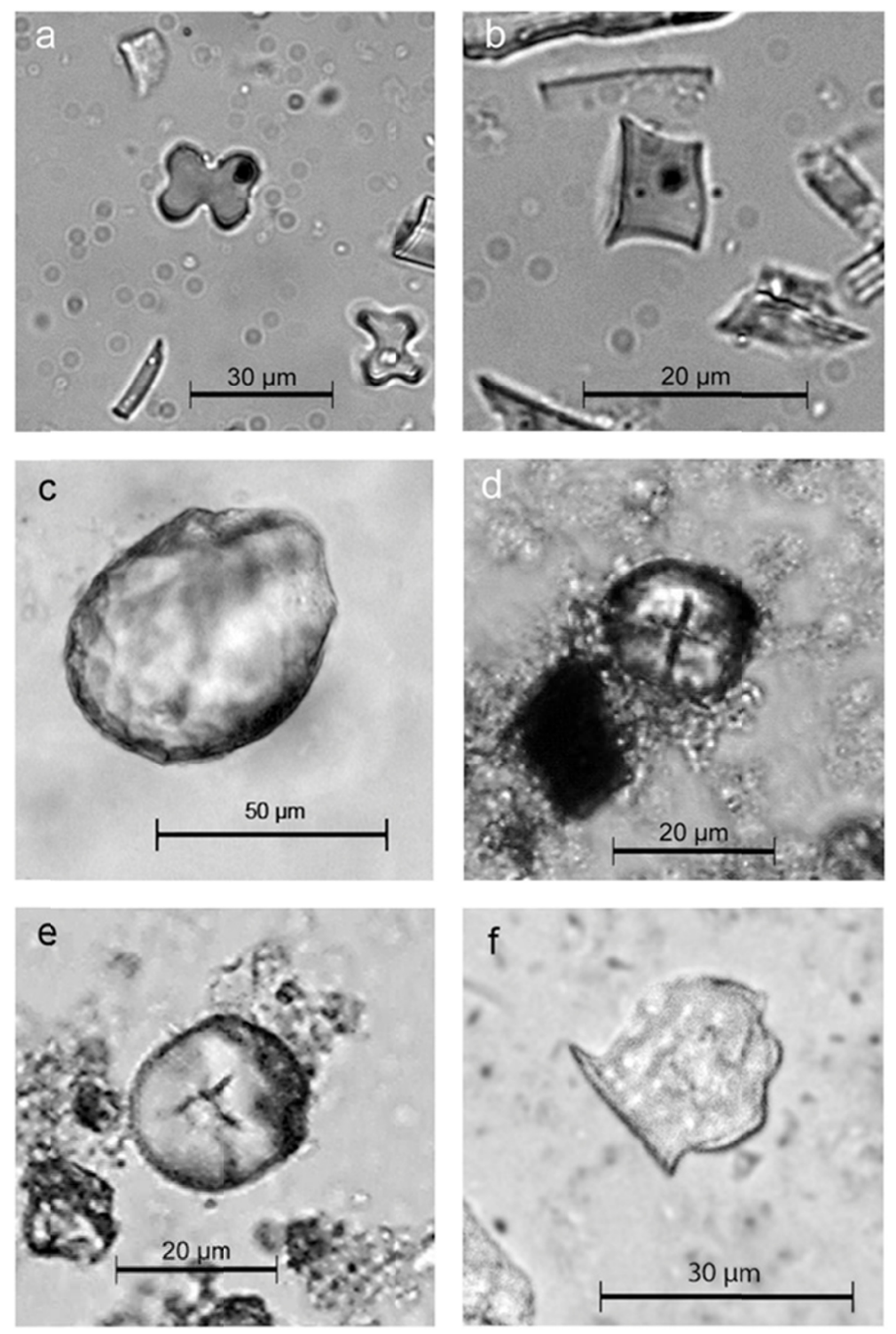

Figure 13. Microfossils in soils and on ceramic sherds from raised field sites, French Guiana

A. Zea mays leaf phytolith, Bois Diable, Mound 1, 0-10 cm.

B. Zea mays cob phytolith, K-VIII, Mound 1.1., 10-20 cm.

C. Cucurbit species rind phytolith, Piliwa, Ridge Field 1., 0-10 cm.

D. Zea mays starch grain from sherd, Sable Blanc, PN 69.

E. Manihot esculenta starch grain from sherd, Sable Blanc, PN 69.

F. Zea mays cob phytolith, Piliwa, Ridge Field 2, 0-10 cm. (McKey et al. 2010:7825, Figure 3) 


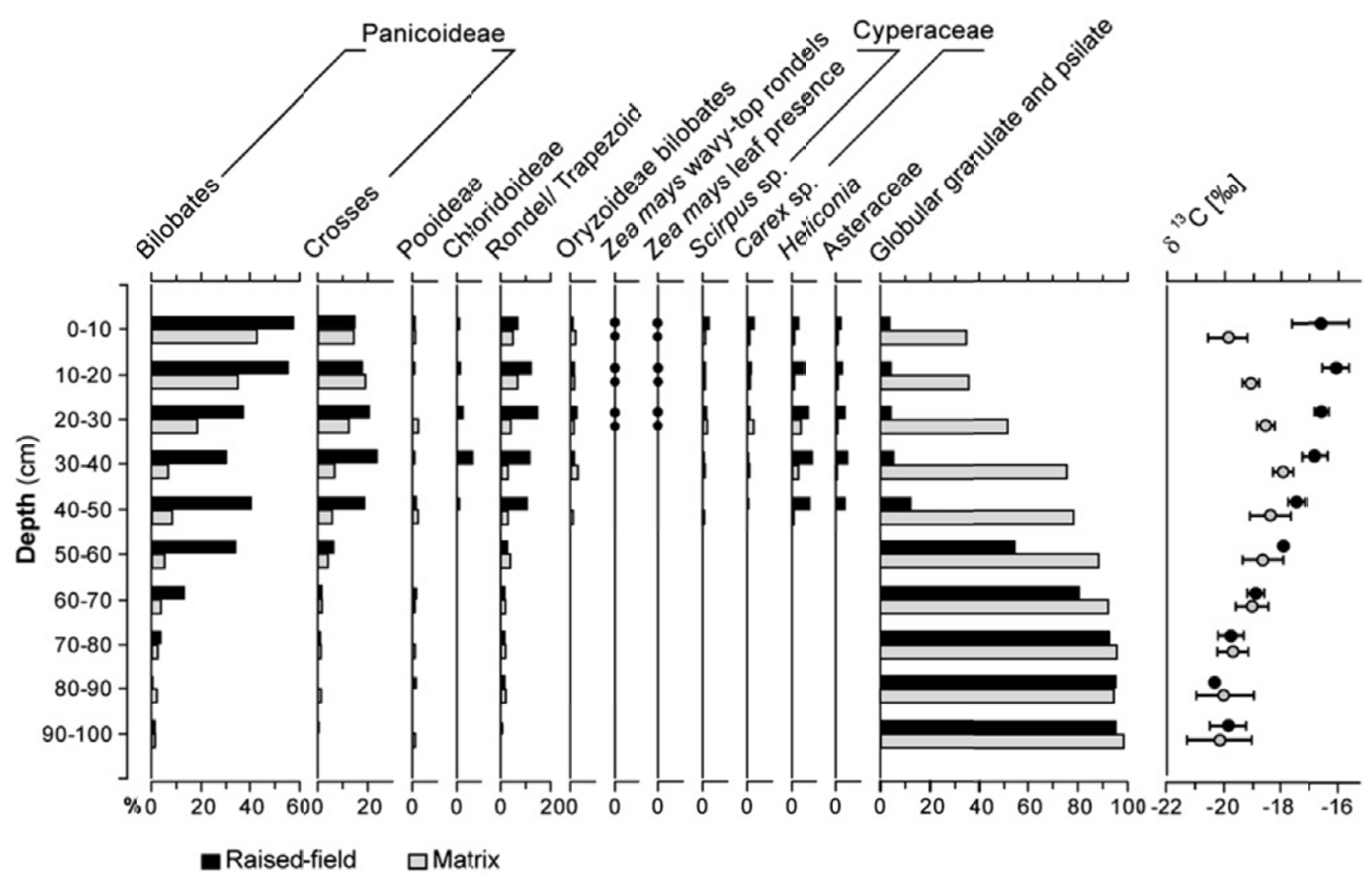

Figure 14. Phytolith and stable isotope distribution by depth in raised field, Savane Grand Macoua, French Guiana (Iriarte et al. 2010:2990, Figure 8)

Even when maize was a staple, in some cultures people continued to cultivate a wide range of crops and to rely substantially on certain collected resources, especially fish (references collected in Roosevelt, 2014). The information on other prehistoric plant foods is extremely scarce, scattered, and uncertain, as mentioned in the epistemology section. At Parmana, late prehistoric deposits produced carbonized jack beans (Canavalia ensiformis), the palm Corozo (Acrocomia aculeata), the tree fruit nance (Byrsonima crassifolia), hog plum (Spondias mombin), inflorescences, leaves, and numerous carbonized tubers, as yet unidentified (Roosevelt, 1980; Smith \& Roosevelt, 1985).

At los Mangos de Paraguaza and Pozo Azul Norte 1, also in the middle Orinoco, only seven and three grains of the root bearing plants Maranta and Myrosoma genera were identified, respectively, so they were much less common than maize (Perry, 2002a, 2004). All other plants - manioc, Dioscorea, beans, etc., were only present as one or two grains (Perry, 2004). A very few possible manioc starch grains also have been recovered from at several Formative sites in Columbian river valleys draining to the Caribbean (see the section on the Formative). Two crops other than maize were identified in phytolith analysis in the Guianas' raised fields: squash and manioc, but these were much less common than the maize (Iriarte et al., 2010). Carbonized endocarps of the domesticated peach palm has been recovered from prehistoric sites in Colombia (Morcote-Ríos \& Bernal, 2001) and at Santarem, Brazil (Roosevelt, 2000), but not usually in large quantities, despite the greater durability of its seeds compared to maize remains. It has only been recovered from late Formative, late prehistoric, and historic-age sites (Morcote-Ríos \& Bernal, 2001; Roosevelt, 2000). The late chronological occurrence of this domesticate is consistent with the conservative assessment for early agriculture in the northern tropical lowlands: that full, staple agriculture based on domesticated plants is a relatively late prehistoric phenomenon.

Thus, despite the long delay, it seems incontrovertible that maize cultivation did crowd out most other foods in certain societies of the Arauquinoid horizon, despite the doubts of some ethnographers specializing in cassava-staple societies (e.g., Carneiro, 1995) and ecologists interested in tree crops (C. Clement, personal communication, 1990). Neither manioc, other $C_{3}$ roots crops or tree crops could have had a quantitatively significant role in diets of the people with the strong $\mathrm{C}_{4}$-pattern stable isotope bone ratios found in the middle Orinoco (Figure 5 and Table 2). Despite such a monotonous diet, people maintained good height, though their teeth were more worn and their bones had less density and larger marrow cavities than those of Formative people 
there. Nonetheless, the non-maize foods that remained in the diet seem to have prevented nutritional deficiencies serious enough to cause recognizable bone pathologies.

\subsubsection{The Agricultural Societies and Their Cultivation Systems}

The initial change in maize's role was contemporary with supraregional socio-political changes starting to take place at the time. (The skeletons showing high maize consumption are dated to the very beginning of the development of Arauquinoid culture styles.) While Archaic and Formative societies in the northern lowlands did sometimes build mounds for ceremonial or residential purposes and had feasting cultures (Roosevelt, Douglas, Bevan, Imazio da Silveira, \& Brown, 2012), the Arauquinoid societies in late prehistory had elaborate ceremonial and funerary practices and built house mounds and large formal complexes of mounds with ramps and causeways at their centers (Roosevelt, 2013). Sites are larger, more numerous, more hierarchical in size distribution, than before, and often include the black Indian soil layers that are considered to be refuse from urban-like settlements (Lehman, Kern, Glaser, \& Woods, 2003). The contrast in magnitude between ancient and modern indigenous settlements in northern South America has been difficult for some ethnographers to accept (Heinen \& Garcia-Castro, 2000, p. 561).

Ethnohistoric sources for the Orinoco and Caribbean and other areas of Arauquinoid cultural influence coasts gives evidence for paramount chiefships held by men and also women (Roosevelt, 1980, 1991). Another contemporary development was intensified communication among regional societies. Although many regions engaged in the Formative Saladoid-Barrancoid horizon, this took place over a long period of time in contrast to spread of the late prehistoric horizon, whose styles have closely similar timing of appearance. The later horizon's iconography has an emphasis on humans, especially females (Cruxent \& Rouse, 1958-1959; Roosevelt, 1980, 1997; Versteeg, 2008), rather than the animals that predominated in the earlier art. Careful lapidary works, interpreted as female ornaments, based on ethnohistoric accounts, were exchanged widely in the horizon zone (Boomert, 1987; Versteeg, 2008). Pottery production also changes in many places: from careful, elegantly sculptured, fine, hard, grit-tempered forms in the Formative to hasty, sloppy, light-weight, sponge-spicule-tempered forms of late prehistory. As in the Formative, the new ceramic horizon seems to appear first in a decoratively simpler form in the Orinoco, among the Barrancoid styles of the late Formative Corozal phase, but research may change the origin of the horizon, as more regional sequences are constructed, and the origin of the geographic the new styles can be traced. The highest development of the style, centered at the major ceremonial and residential site of Santarem in the lower Amazon, Brazil, is, however, one of the latest cultures of the horizon, starting no earlier than 800 BP (Gomes, 2001; Nimuendajú 2004; Roosevelt, 1999; 2000).

Concurrent with the increase in population and the rise of staple maize cultivation during the period of influence from the Incised and Punctate horizon, c. AD 500 and 1500, large areas of wetlands in several parts of northern lowland South America were converted to raised agricultural fields, in some cases covering as much as 10000 square kilometers. Such areas have been found in the western (Denevan \& Zucchi, 1978; Garson, 1980 Spencer \& Redmond, 2014; Spencer \& Redmond, 1998; Spencer et al., 1994; Zucchi \& Denevan, 1979), central, and northeastern Orinoco and piedmont and the coastal lowlands of the Guianas (Rostain, 2008; $2013 \mathrm{a}$ and b; Versteeg, 2008; Versteeg \& Bubberman,1992). Shapes and sizes of fields were very diverse, often clustered by shape type, but all seem to have been constructed by digging drainage ditches and by heaping the mud from them on top of the fields (Figures 11, 12). Causeways, canals, and ponds are associated spatially with the field systems. The fields are generally interpreted as a method of creating and fertilizing permanent cultivation surfaces to expand production beyond gardening and swiddening (Rostain, 2008ab; 2013). They have been called an extension of floodplain agriculture because they multiply the area of possible planting surfaces in floodplains (Versteeg, 2008). Maize specimens predominate among the botanical identifications from the fields and adjacent settlements, though the relative rarity of manioc and other plants could be a preservation problem (Figures 13, 14). The possibility that wild rice varieties, common among raised field microfossils, were cultivated (suggested by Brochado, 1980) has not yet been investigated.

Most raised fields are associated with Arauquinoid styles of the late Incised and Punctate horizon of the Orinoco, but a few field systems were erected by people using pottery styles affiliated with the late Barrancoid culture, among which the earliest Arauquinoid styles in the middle Orinoco sequence developed. Late Barrancoid raised fields dating between about AD 100 and 300 were identified in Surinam. Early Arauquinoid sites are found alongside raised fields in the western Orinoco plains of Venezuela and in the Guianas coastal plains of Surinam between about AD 300 and 700 to1000 AD. Most raised fields investigated, however, date after AD 1000, and a few constructions have turned out to be post-conquest. Modern people occasionally renovate and cultivate the prehistoric ones sometimes for maize, sometimes for root crops (e.g., Spencer \& Redmond 2014; Rostain, 2008a: $225)$, but most of those investigated have produced prehistoric artifacts and/or radiocarbon dates. 
Thus, it seems that only during the last 1500 years or so of prehistory during a period of intense complex society development and population expansion that we have secure evidence of true agriculture that produced the majority of the food in the societies. It is interesting that the particular geomorphological zones where this happened were those with significant areas of floodplains and wetlands. Thus, intensive, permanent cultivation apparently was focused presciently on low-lying alluvium and not on upland terrain that might be subject to erosion and depletion of soil nutrients under permanent cultivation.

\section{Agriculture Today}

Despite its importance in the agriculture of late prehistory, maize is not often a staple food today among most indigenous groups in the Orinoco and Amazon in the sense of providing the majority of food calories, which manioc more often provides, or introduced plants like banana and plantain. In fact, based on ethnography, the Orinoco was originally expected to have been a manioc-staple area in prehistory (Rouse \& Cruxent, 1963), an expectation that the research at Corozal refuted. The assumption that ethnographic patterns were a stable adaptation that necessarily represented ancient patterns was a Radcliffe-Brownian way of thinking that most archaeologists, at least, have long since abandoned. This is not to say that the rich ethnographic record and living populations are not an essential primary source of understanding, especially for indigenous people's views and knowledge about issues of interest to anthropologists, ethnobotanists, and geographers. Without this record, we would be hard put to parse the archaeological record, but we shouldn't be constrained by it from glimpsing other ways for other times.

Thus, the cultivation of different crops and the degree of reliance on them in ethnographically observed societies may not be a good indication of early prehistoric patterns. By definition, subsistence changed through time in prehistory, and ethnographic patterns presumably could not be representative of all the many different prehistoric periods (Roosevelt, 1994b). Some of the recent changes in ethnographic crop emphasis in northern South America may be related to various post-conquest effects. Most areas lost population at least at first, and the cohesive string of Arauqinoid societies that had pursued staple maize economies, farmed floodplains, and sometimes built raised fields, soon disappeared. In both the Amazon, Orinoco, and also in the Guianas, the ending radiocarbon dates of incised and punctate societies, cited in section 3.5.3 (The agricultural societies and their cultivation systems), show that most of the societies fell apart soon after the conquest. The initial reason for the abandonment of the raised fields may have been the loss and flux of population during the conquest, but foreign settlers soon entered and intervened in the situation. Some societies survived into the early contact period by letting go of old lifeways and developing ones related to the new economies and social contexts, such as cattle ranching, extractive collection, guiding, and portering. Only a few native groups continued to make and use raised fields after the European conquest: the Palikur in northern Brazilian Guiana, Amapá, for manioc and yams, and Karina in the northeast Orinoco in Venezuela for maize and other crops (Denevan \& Schwerin, 1978; Rostain, 2008a). Careful work with peasant farmers in Amapá, Brazilian Guiana (Padoch \& Pinedo-Vasquez, 1999; Raffles, 1999), and French Guiana (Rostain, 2013 b) has revealed that the practice continues among them, too, in limited ways.

Although many people speaking Arawak or Carib continued to cultivate maize north of the Orinoco into the 19th century, that area now is dominated by Spanish-speaking ranchers who and eat maize as a staple. Native people still live south, east, and west of the Orinoco, and manioc and/or bananas tend to be their staple food, produced in shifting horticultural fields, rather than permanent fields. Flour or cakes made from manioc are usually the most common everyday foods consumed on a seasonal basis along with fish (Roosevelt, 1994a). People also eat a wide range of fruits from trees and palm, which are for the most part native species that are managed, cultivated, and disseminated by people but that are not domesticated species in the strict sense of the term. Peach palm stands out among all these as a species whose groves do not flourish nowadays without human management (Clement, 1990; Mora-Urpi, Weber, \& Clement, 1997; Politis, 2009). Only in the more distant indigenous communities do people get much of their plant food from palms, though, especially peach palm and other orchard trees (e.g., Politis, 2009; Smole, 1976). For example, interior Orinoco groups such as some Yanomamo people still cultivate peach palm as one among several staple foods (Smole, 1976). Moriche palm (Maurita excelsa) fruits, stem sap, and stem starch eaten with fish used to be a staple in the large population of Warao inhabiting the Orinoco delta, and the Warao used for minor purposes many of the same taxa as Paleos and Archaics: including Euterpe, Erythrina, Manilkara, and Virola (Heinen, 1988). The intrusion of missionaries and Euro-American farms and businesses in this century, has led Warao to change to slash and burn subsistence farming and wage labor.

Maize is now a staple in much of Venezuela and Colombia, outside of indigenous areas. Slash and burn cultivation and house gardens produce the main subsistence crops. Like the ancient and modern indigenous 
farmers, most modern people also cultivate a large variety of native species in addition to their staples, some of them for other than basic food purposes. Also like native people, peasants make specialty foods and drinks from succulent or nutritious tree and palm fruits such as Brazil nut or açaí (Euterpe) for consumption in ceremonial contexts. Other peasant plant staples are beans, some the minor indigenous crops, and introduced crops, such as rice, bananas, and plantain. Native root crops such as sweet potato, arrowroot, and Xanthosoma also are more common foods in rural communities distant from national urban centers than they are in communities oriented to urban or global markets.

Most Spanish-speaking rural people in the modern nations of the northern lowlands employ systems of production linked to local or outside markets (Roosevelt, 1980, 1991; Adams \& Murrieta, 2009). Cattle ranching is important among them, as is the raising of small stock for their own use, also recently taken up by some indigenous people, as in the Gran Sabana of Venezuela. Ranching is rapidly displacing the agroforestry of both peasants and indigenous peoples in Amazonia and in the Orinoco (e.g., Hecht, 1990; Hecht \& Cockburn, 2011; Peters et al., 1989; Schmink \& Woods, 1992), and the oil industry has further transformed Caribbean coast and middle and lower Orinoco landscapes. All these changes mean that researchers interested in studying and fostering rural people's management and use of plants and native plants' ecology and genetics will have to hasten there before the people and the plants are gone forever.

\section{Conclusions}

It seems very likely that the early migrants to northern South America understood the principle of planting and may have planted some species of major importance in their cultures. Ethnohistoric evidence on hunter-gatherer societies that survived into the early contact period, such as indigenous California peoples, demonstrate that they frequently managed non-domesticated plants in the same ways that agricultural people manage domesticates, planting, pruning, fertilizing, building terraces for them, etc. (e.g., Blackburn \& Anderson, 1993) Despite the lack of comprehensive archaeological evidence, our sequences give some hints of what more definitive research in the future may discover along those lines.

The Paleoindians congregated or returned regularly for appreciable periods at food-rich locales, but in territories with sparser food sources, they stayed less time at sites. The common use of certain lithic forms and technologies over wide areas shows that they traveled and communicated actively with people in other regions. It is clear that plants were important in their diet and industries. Many of the palms and some of the trees now cultivated as important seasonal staples in the northern tropical lowlands later on were staple food sources for Paleoindians, along with fish, turtles, shellfish, and small land animals. Where faunal food remains are not preserved or not collected during excavation, we can't assume that they were not important, and because of stratigraphic and preservation imponderables, it's not yet clear whether Paleos used any of the herbaceous plants that later became cultigens in the area. But they weren't big-game specialists, contrary to the thinking of early Paleo experts. The manifest importance of plant foods in the period suggests that careful study could reveal some kind of purposeful plant management. On the analogy of ethnographic studies, also, their occupation sites must at least have had an impact on the local plant population.

Some Archaic people settled down permanently where food species abounded naturally or became concentrated by germination in refuse heaps. When their chosen food resources were more scattered, they roamed their regions. Subsistence thus became much more diversified regionally in the Archaic than before. Some people - as at Taperinha and other sites in the lower Amazon and Amazon mouth - used fish, shellfish, and turtles as staple foods, and tree and palm fruits are rare in their sites. These communities may not have had a role in early cultivation, contrary to the theories of Sauer and Lathrap. Some other people - at San Jacinto in the lower Magdalena River - collected and intensively processed herbaceous plants that bore roots or seeds and collected large univalves. They may have had a role in domesticating those root-bearing herbs, but those local seed plants were not ultimately brought into cultivation, as best we know. All these latter groups also make pottery, much of it very ornately decorated. Some preceramic Archaic people - at Peña Roja, in the northwest Amazon and Provincial and Culebra, in the middle Orinoco - emphasized the palm and tree fruits Paleoindians had emphasized; fauna might have been eaten, but their remains are not preserved or were not targeted by the archaeologists' collection methods. Perhaps the domestication of selected palms and fruit trees took place in those kinds of Archaic sites. Other preceramic people living outside of the floodplains and wetlands in Colombia appear to have relied on a variety of forest herbs and tuber or corm bearing plants. Perhaps those herbs ultimately became domesticated there, too, but most sequences are too incomplete to show that process. The uplands of the Guianas also had early Archaic sites, but analysis of their cultures and ways of life is just beginning. 
During the Formative, people with rich conceptual and material cultures spread slowly through the lowlands, establishing modest-sized but highly organized settlements on the basis of varied and nutritious subsistence from both collected plants and animal foods and cultivated plants. So far the clearest evidence for maize cultivation is from their sites, in the later part of the period c. 4500 to 1500 BP. The evidence varies but includes numerous identified microfossils, directly dated maize kernels, and $\mathrm{C}_{4}$ stable isotope ratios in some food remains. Perhaps among these late Formative groups were those who first selected out the maize varieties that became the productive races that later became staples. That appears to be a process indigenous to the northern lowlands, since the maize races that were developed for tropical environments, like Chandelle, are local to the region, not introduced from somewhere else. But maize is definitely not an early Formative staple, for their bones show little or no effects of substantial maize consumption. Their presumed cultivation system - based on root crops, the maize, palms, and fruit trees - seems better described as mixed horticulture and agroforestry than agriculture, given its lack of specialization and the low intensity of cultivation.

Agriculture, which is definitely based on maize, is only documented in late prehistory, between about 1500 and 500 years ago, and only in certain landscape contexts as floodplain or wetland raised field cultivation, and in certain socio-political contexts: sedentary, stratified societies with conspicuous leaders. The cultures that pursued this labor-intensive and potentially unhealthy lifeway were a closely related group: named Arauquinoid after the Orinoco site where their pottery was first found. They both negotiated and fought to establish relationships for trade, intermarriage, ceremonial systems, and political alliances. Their influence reached far, though not as far as that of the Formatives. Arauquinoid art has turned up from the Caribbean coast and Islands to Amazon mouth and the Bolivian Amazon. The maize that they primarily relied on in their Orinoco area of origin was a race developed locally, unlike the maize race that appears earliest, which has highland links outside the lowlands. The long delay the use of maize as a staple, proven by the significant negativity of human stable carbon isotope ratios until late prehistory, suggests that open-field agriculture was not a system that early lowland foragers found very interesting or useful.

Perhaps the model of early farming in the region should not be slash-and-burn field horticulture but some preliminary form of forest management. Perhaps Archaic sites represent the initial stage of intensive use and manipulation of plants when settlement became more localized due to the settling of most regions, preventing free roaming, as several authors have suggested. Most of the macro-plant remains recovered from Archaic sites in the tropical forest of the northern lowlands of South America come from palms, shrubs, or trees. Although there has not been a broad, systematic effort to recover and identify palm and tree remains from lowland archaeological sites, many specimens have been recovered through routine field methods. It's been hypothesized that the one certain Neotropical domesticated palm, peach palm (Bactris gasipaes), was first domesticated in the northwestern lowlands of Colombia (Morcote-Ríos \& Bernal, 2001), but systematic sampling of modern and ancient palms has yet to be carried out. Many indigenous communities in the northern Amazon, Orinoco, and Guianas still have extensive plantings of palms and trees (e.g., Politis, 2009; Smole, 1976), especially including this species. Nearly all the economic palms are regularly planted and their fruits are eaten in abundance in season in greater Amazonia (Goulding \& Smith, 2007; Smith et al., 2007; Henderson, 1995), and a number of tree species' fruits also are seasonal staple foods (Smith et al., 2007). But when cultivation of all these species began is an open question. The problem with tracing palm and tree cultivation is that many of the regularly planted species do not show obvious effects from being cultivated.

It's obvious what is needed to start to clarify the picture of early plant use. To avoid the sampling artifacts that flaw knowledge of distributions, plant researchers investigating the ancestors of cultigens need to adopt explicit sampling procedures that cover the entire range of possible habitats and record where sampling was done and not done. Genetic testing must be applied more intensively and extensively, including analysis of ancient specimens. Geneticists need to use multiple working hypotheses and avoid premature conclusions from limited sampling and data analysis. Archaeologists need to adopt much more comprehensive excavation and soil-processing methods to collect a wider range of remains and to record and acknowledge disturbances that affect interpretation. Archaeologists and laboratory researchers need to adopt clean procedures and controls to protect finds and to detect contamination. Identifications will mean more when more are accomplished and results presented more openly for discussion and debate. Distributions need to be statistically analyzed for significance or lack of significance. And current food, foraging, and cultivation systems must be studied more extensively and more humbly, seeking ethnographic illumination from those who still actively design and carry them out.

\section{Acknowledgements}

Thanks to Brazil Reid for inspiring me to take a new look at a topic I explored for my dissertation in the 1970s. In numerous conversations and correspondence, Bill Balee and Nigel Smith have helped me develop my 
thinking about humans in the tropical forests. I followed Junius Bird as an example of the need to keep refining my excavation and analytic methods, and Phyllis Dillon showed me how to safely handle and store materials in the collections from research. I would like to acknowledge the help of the many collaborators in my field projects. I've named them all in our collaborative publications. Without them, the research would have been limited indeed. I also thank the many authors who published the works cited in this article. Their contributions made it possible for me to glimpse some possible patterns in the disparate data from northern South America and the Caribbean coasts and some directions for future research. Thanks, also, to the authors who gave permission for the use of their illustrations and to Linda J. Brown for her careful copyediting.

\section{References}

Aceituno, F. J., \& Castillo, N. (2005). Mobility strategies in Columbia's middle mountain range between the early and middle Holocene. Before Farming, 2, 1-17. http://dx.doi.org/10.3828/bfarm.2005.2.2

Aceituno, F. J., \& Loaiza, N. (2014). Early and middle Holocene evidence for plant use and cultivation in the middle Cauca River Basin, Cordillera Central (Colombia). Quaternary Science Reviews, 86, 49-62. http://dx.doi.org/10.1016/j.quascirev.2013.12.013

Aceituno, F. J., \& Loaiza, N. (2015). The role of plants in the early human settlement of northwest South America. Quaternary International, 363, 20-27. http://dx.doi.org/10.1016/j.quaint.2014.06.027

Aceituno, F. J., Loaiza, N., Delgado-Burbanoc, M. E., \& Barrientos, G. (2013). The initial human settlement of northwest South America during the Pleistocene/Holocene transition: Synthesis and perspectives. Quaternary International, 301, 23-33. http://dx.doi.org/10.1016/j.quaint.2012.05.017

Adams, C., \& Murrieta, R. (Eds.). (2009). Amazon peasant societies in a changing environment: Political ecology, invisibility and modernity in the rainforest. New York, NY: Springer.

Adams, R. M. (1966). The evolution of urban society. Chicago, IL: Aldine.

Anderson, A. B. (1988). Use and management of native forests dominated by açaí palm (Euterpe oleracea Mart.) in the Amazon estuary. Advances in Economic Botany, 6, 144-154.

Anderson, A. B., May, P. H., \& Balick, M. J. (1991). The subsidy from nature: Palm forests, peasantry, and development on an Amazon frontier. New York, NY: Columbia University Press.

Arnold, J. E. (Ed.). (1996). Emergent complexity: The evolution of intermediate societies. Archaeological Series 9, Ann Arbor, MI: International Monographs in Prehistory.

Bailey, R. C. Head, G., Jenike, M., Owen, B., Rechtman, R. \& Zechenter, E. (1989). Hunting and gathering in a tropical rainforest: Is it possible? American Anthropologist, 91, 59-82. http://dx.doi.org/10.1525/aa.1989.91.1.02a00040

Barse, W. P. (1990). Preceramic occupations in the Orinoco river valley. Science, 250, 1388-1390. http://dx.doi.org/10.1126/science.250.4986.1388

Barse, W. P. (2000). Ronquín, AMS dates, and the middle Orinoco sequence. Interciencia, 25, 337-341.

Barse, W. P. (2003). Holocene climate and human occupation in the Orinoco. In J. Mercader (Ed.), Under the canopy: The archaeology of tropical rainforests (pp. 249-270). New Brunswick, NJ: Rutgers University Press.

Barton, H., \& Torrence, R. (2006). Looking ahead. In R. Torrence \& H. Barton (Eds.), Ancient starch research, (pp. 217-224). Walnut Creek, CA: Left Coast Press.

Benz, B. F. (2001). Archaeological evidence of teosinte domestication from Guilá Naquitz, Oaxaca. Proceedings of the National Academy of Sciences, 98, 2104-2106. http://dx.doi.org/10.1073/pnas.98.4.2104

Blackburn, T. C., \& Anderson, K. (1993). Before the wilderness: Environmental management by native Californians. Menlo Park, CA: Ballena Press.

Boomert, A. (1980). Hertenrits: An Arauquinoid complex in north west Suriname, (Part 1). Journal of the Walter Roth Museum of Archaeology and Anthropology, 3(2), 68-105.

Boomert, A. (1983). The Saladoid occupation of Wonotobo Falls, western Surinam. In Proceedings of the 9th International Congress for the study of the Pre-columbian cultures of the Lesser Antilles (pp. 97-120). Montreal, Canada: University of Montreal Press.

Boomert, A. (1987). Gifts of the Amazons: "Greenstone" pendants and beads as items of ceremonial exchange in Amazonia. Antropológica, 67, 33-54. 
Boomert, A. (2000). Trinidad, Tobago, and the lower Orinoco interaction sphere: An archaeological/ethnohistorical study. Alkmaar: Cairi Publications.

Boomert, A., Faber-Morse, B., \& Rouse, I. (2013). The 1946 and 1953 Yale University excavations in Trinidad. Yale University Publications in Anthropology, Vol. 92. New Haven, CT: Yale University.

Bradley, D. (2006). Documenting domestication: Reading animal genetic texts. In M. Zeder, D. G. Bradley, E. Emshwiller, \& B. C. Smith (Eds.), Documenting domestication: New genetic and archaeological paradigms (pp. 273-278). Berkeley, CA: University of California Press. Retrieved from http://www.jstor.org/stable/10.1525/j.ctt1pnvs1.23

Braidwood, R. J., \& Reed, C. A. (1957). The achievement and early consequences of food-production: A consideration of the archaeological and natural-historical evidence. In Cold Spring Harbor Symposia on Quantitative Biology, (Vol. 22, pp. 19-31). Cold Spring Harbor Laboratory Press. http://dx.doi.org/10.1101/SQB.1957.022.01.006

Brochado, J. P. (1980). The social ecology of the Marjajoara culture (Unpublished master's thesis). University of Illinois, Urbana, U.S.A.

Buckler, E. S., \& Stevens, N. M. (2006). Maize origins, domestication, and selection. In T. J. Motley, N. Zerega, \& H. Cross, H. (Eds.), Darwin's harvest: New approaches to the origins, evolution, and conservation of crops (pp. 67-90). New York, NY: Columbia University.

Bush, M. B., Piperno, D. R., \& Colinvaux, P. A. (1989). A 6,000 year history of Amazonian maize cultivation. Nature, 340, 303-305. http://dx.doi.org/10.1038/340303a0

Cano, A., Young, K. E., Leon, B., \& Foster, R. (1995). Composition and diversity of flowering plants in the upper Montane forest of Manu National Park, southern Peru. In S. P. Churchill, H. Balsley, E. Forero, \& J. L. Luteyn (Eds.), Biodiversity and conservation of neotropical montane forests (pp. 271-280) New York, NY: The New York Botanical Garden.

Carneiro, R. L. (1970). A theory of the origin of the state. Science, 169, 733-738.

Carneiro, R. L. (1995). The history of ecological interpretations of Amazonia: Does Roosevelt have it right? In L. E. Sponsel (Ed.), Indigenous peoples and the future of Amazonia: An ecological anthropology of an endangered world (pp. 45-70). Tucson: University of Arizona.

Castillo, N., \& Aceituno, F. (2006). El bosque domesticado, el bosque cultivado: Un proceso milenario en el Valle Medio del Río Porce en el Noroccidente Colombiano. Latin American Antiquity, 17, 561-578. http://dx.doi.org/10.2307/25063072

Clement, C. R. (1990). Regeneração natural de pupunha (Bactris gasipaes). Acta Amazonica, 20, 399-403. http://dx.doi.org/10.1590/1809-43921990201403

Clement, C. R., de Cristo-Araújo, M., Coppens D’Eeckenbrugge, G., Alves Pereira, A., \& Picanço-Rodrigues, D. (2010). Origin and domestication of native Amazonian crops. Diversity, 2, 72-106. http://dx.doi.org/10.3390/d2010072

Crowther, A., Haslam, M., Oakden, N., Walde, D., \& Mercader, J. (2014). Documenting contamination in ancient starch laboratories. Journal of Archaeological Science, 49, 90-104. http://dx.doi.org/10.1016\%2Fj.jas.2014.04.023

Cruxent, J. M., \& Rouse, I. (1958 \& 1959). An Archaeological Chronology of Venezuela. 2 Vols. Social Science Monographs, No. 6. Pan American Union, Washington, DC.

Davis, C. S. (2009). Archaeoastronomy at Monte Alegre, Pará: A research problem and research strategy. Amazônica, 1, 536-547.

Davis, C. S. (2014). Archaeoastronomy of terminal Pleistocene rock art on the Amazon river at Monte Alegre, Pará, Brazil (Unpublished doctoral dissertation). University of Illinois, Chicago, USA.

de la Penha, G. M. S. M., Bruni, S. A., \& Papavero, N. (Eds.). (1986). O Museu Paraense Emílio Goeldi. Conselho Nacional de Desenvolvimento Cientifico e Tecnológico and Banco Safra: São Paulo.

Denevan, W., \& Schwerin, K. H. (1978). Adaptive strategies in Karina subsistence, Venezuelan llanos. Antropologica, 50, 3-91.

Denevan, W., \& Zucchi, A. (1978). Ridged field excavations in the Central Orinoco llanos, Venezuela. In D. Browman (Ed.), Advances in Andean archaeology (pp. 235-245). Mouton, The Hague. 
Diamond, J., \& Bellwood, P. (2003). Farmers and their languages: The first expansions. Science, 300, 597-603. http://dx.doi.org/10.1126/science. 1078208

Dickau, R., Aceituno, F. J., Loaiza, N., López, C., Cano, M., Herrera, L., ... \& Ranere, A. J. (2015). Radiocarbon chronology of terminal Pleistocene to middle Holocene human occupation in the Middle Cauca Valley, Colombia. Quaternary International, 363, 43-54.

Dimbleby, G. W. (1985). The palynology of archaeological sites. New York, NY: Academic Press.

Drew, R. (2009). From Saladoid to Taíno: Human behavior from human remains in the Greater Antilles. Bulletin of the Peabody Museum of Natural History, 50, 167-185. http://dx.doi.org/10.3374/014.050.0112

Emshwiller, E. (2006). Genetic data and plant domestication. In M. A. Zeder, D. G. Bradley, E. Emshwiller, \& B. D. Smith (Eds.), Documenting domestication: New genetic and archaeological paradigms (pp. 99-122). Berkeley: University of California Press.

Erickson, C. L. (2008). The historical ecology of a domesticated landscape. In H. Silverman \& W. H. Isbell (Eds.), The handbook of South American archaeology (pp. 157-183). New York, NY: Springer.

Erlandson, J. M., \& Braje, T. J. (Eds.). (2013). When humans dominated earth: Archaeological perspectives on the Anthropocene. Anthropocene Special Issue 4, 1-122.

Eubanks, M. W. (2006). Contributions of Tripsacum to maize diversity. In T. J. Motley, N. Zerega, \& H. Cross (Eds.), Darwin's harvest: New approaches to the origins, evolution, and conservation of crops (pp. 91-120). New York, NY: Columbia University Press.

Evans, C., \& Meggers, B. J. (1960). Archeological investigations in British Guiana. Smithsonian Institution Bureau of American Ethnology Bulletin 177, Washington, DC: Government Printing Office.

Fewkes, J. W. (1914). Prehistoric objects from a shell-heap at Erin Bay, Trinidad. American Anthropologist,16, 200-220.

Fishkis, O., Ingwersen, J., \& Streck, T. (2009). Phytolith transport in sandy sediment: Experiments and modeling. Geoderma, 151, 168-178.http://dx.doi.org/10.1016/j.geoderma.2009.04.003

Flannery, K. V. (1965). The ecology of early food production in Mesoamerica. Science, 147, 1247-1256.

Flannery, K. V. (1973). The origins of agriculture. Annual Review of Anthropology, 2, 271-310.

Fried, M. (1967). The evolution of political society: An essay in political anthropology. New York, NY: Random House.

Fritz, G. J. (1994a). Are the first American farmers getting younger? Current Anthropology, 35, 305-309.

Fritz, G. J. (1994b). On the emergence of agriculture in the New World (reply to Piperno). Current Anthropology, $35,639-643$.

Fritz, G. J. (2005). Paleoethnobotanical methods and applications. In H. G. B. Maschner, \& C. Chippindale (Eds.), Handbook of archaeological methods, (Vol 2, pp. 773-834). Lanham, MD: AltaMira Press.

Fritz, G. J. (2007). Keepers of Louisiana's levees: Early mound builders and forest managers. In T. Denham, J. Iriarte, \& L. Vrydaghs (Eds.), Rethinking agriculture: Archaeological and ethnoarchaeological perspectives (pp. 189-210). Walnut Creek, CA: Left Coast Press.

Garson, A. G. (1980). Prehistory, settlement, and food production in the savanna region of La Calzada de Paez, Venezuela (Unpublished doctoral dissertation) Anthropology. Yale University, New Haven USA.

Gaspar, M. D., DeBlasis, P., Fish, S. K., \& Fish, P. R. (2008). Sambaqui (shell mound) societies of coastal Brazil. In H. Silverman, \& W. H. Isbell (Eds.), The handbook of South American archaeology (pp. 319-335). New York, NY: Springer.

Gassón, R. A. (1998). Prehispanic intensive agriculture, settlement pattern and political economy in the western Venezuelan llanos (Unpublished doctoral dissertation). University of Pittsburgh, Pittsburgh.

Gassón, R. A. (2002). Orinoquia: The archaeology of the Orinoco River Basin. Journal of World Prehistory, 16, 237-311. http://dx.doi.org/10.1023/A:1020978518142

Gnecco, C. (2000). Occupación temprana de bosques tropicales de montana. Popayán, Colombia: Universidad del Cauca.

Gnecco, C., \& Aceituno, J. (2006). Early humanized landscapes in northern South America. In J. E, Morrow, \& C. Gnecco (Eds.), Paleoindian archaeology: A hemispheric perspective (pp. 86-104). Gainesville, University of Florida Press. 
Gnecco, C., \& Mora, S. (1997). Late Pleistocene/early Holocene tropical forest occupations at San Isidro and Pena Roja, Colombia. Antiquity, 71, 683-690.

Gomes, D. (2001). Santarém: Symbolism and power in the tropical forest. In C. McEwan, C. Barreto, \& E. Neves (Eds.), Unknown Amazon: Culture and nature in ancient Brazil (pp. 134-155). London: British Museum.

Goulding, M., \& Smith, N. (2007) Palms: Sentinels for Amazon conservation. St. Louis: Amazon Conservation Association and Missouri Botanical Garden Press.

Grant, U. J., Hatheway, W. H., Timothy, D. H., Cassalett D. C., \& Roberts, L. M. (1963). Races of maize in Venezuela. (Vol. 1136). Washington, D.C.: NAS/NRC Publication.

Haberle, S. (1997). Upper Quaternary vegetation and climate history of the Amazon basin: Correlating marine and terrestrial pollen records. R. D. Flood, D. J. W. Piper, A. Klaus, \& L. C. Peterson (Eds.), Proceedings of the Ocean Drilling Program, Scientific Results, 155 , 381-396.http://dx.doi.org/10.2973/odp.proc.sr.155.225.1997

Harris, M. (1968). The rise of anthropological theory: A history of theories of culture. New York, NY: Random House.

Hart, C. W. M., \& Pilling, A. R. (1960). The Tiwi of north Australia. Case studies in anthropology. New York, NY: Holt, Rinehart, \& Winston.

Hart, D. M., \& Humphreys, G. S. (1997). The mobility of phytoliths in soils: Pedological considerations. In A Pinilla, J Juan-Tresserras, MJ Machado (Eds), The state-of-the-art of phytoliths in soils and plants (pp. 93-100). Madrid: Centro de Clencias Medioambientales.

Haslam, M. (2004). The decomposition of starch grains in soils: Implications for residue analysis. Journal of Archaeological Science, 31, 1715-1734. http://dx.doi.org/10.1016/j.jas.2004.05.006

Hastorf, C. A., \& Popper, V. S. (Eds.). (1988). Current paleoethnobotany: Analytical methods and cultural interpretations of archaeological plant remains. Chicago, IL: University of Chicago Press.

Hather, J. (2010). Tropical archaeobotany: Applications and new methods. London, UK: Routledge.

Hecht, S. B. (1990). Indigenous soil management in the Latin American tropics: Neglected knowledge of native peoples. In M. A. Altieri, \& S. B. Hecht (Eds.), Agroecology and small farm development (pp. 151-158). Boca Raton, FL: CRC Press.

Hecht, S. B., \& Cockburn, A. (2011). The fate of the forest: Developers, destroyers, and defenders of the Amazon. Chicago, IL: University of Chicago Press.

Heinen, H. D. (1988). Oko Warao: Marshland people of the Orinoco delta. Münster, Germany: Lit Verlag.

Heinen, H. D., \& Garcia-Castro, A. (2000). The multiethnic network of the lower Orinoco in early Colonial times. Ethnohistory, 47, 561-579.

Henderson, A. (1995). The palms of the Amazon. New York, NY: Oxford University Press.

Herrera, L, Bray, W., Schrimpff, M., \& Botero, P. (1992). Nuevas fechas de radiocarbono para el precerámico en la cordillera occidental de Colombia. In O. R. Ortiz-Troncoso, \& T. van der Hammen, (Eds.), Archaeology and environment in Latin America (pp. 145-163). Proceedings of a symposium held at the 46th International Congress of Americanists, Amsterdam, July 4-8, 1988. Amsterdam: Instituut voor Pre- en Protohistorische Archaeologie Albert Egges van Giffen (IPP), Universiteit van Amsterdam.

Imazio da Silveira, M., \& Schaan, D. P. (2005). Onde a Amazônia encontra o mar: Estudando os sambaquis do Pará. Revista de Arqueologia, 18, 67-79.

Iriarte, J. (2007). New perspectives on plant domestication and the development of agriculture in the New World. Rethinking agriculture: Archaeological and ethnoarchaeological perspectives (pp. 167-188). Walnut Creek, CA: Left Coast Press.

Iriarte, J., Glaser, B., Watling, J., Wainwright, A., Birk, J. J. Renard, D., ... \& McKey, D. (2010). Late Holocene Neotropical agricultural landscapes: Phytolith and stable carbon isotope analysis of raised fields from French Guianan coastal savannahs. Journal of Archaeological Science, 37, 2984-2994. http://dx.doi.org/10.1016/j.jas.2010.06.016

Iriarte, J., Power, M. J., Rostain, S., Mayle, F. E., Jones, H., Watling, J., ... \& McKey D. B. (2012). Fire-free land use in pre-1492 Amazonian savannas. Proceedings of the National Academy of Sciences, 109, 6473-6478. 
http://dx.doi.org/10.1073/pnas.1201461109

Kelso, G. K. (1994). Pollen percolation rates in Euroamerican-era cultural deposits in northeastern United States. Journal of Archaeological Science, 21: 481-488. http://dx.doi.org/10.1006/jasc.1994.1048

Kugler, H. G. (1956). Trinidad. In W. F. Jenks (Ed.), Handbook of South American Geology, Geological Society of America Memoir, (Vol. 65, pp. 351-366). http://dx.doi.org/10.1130/MEM65-p351

Langlie, B. S., Mueller, N. G., Spengler, R. N., \& Fritz, G. J. (2014). Agricultural origins from the ground up: Archaeological approaches to plant domestication. American Journal of Botany, 101, 1601-1617. http://dx.doi.org/10.3732/ajb.1400145

Lathrap, D. W. (1970). The upper Amazon. New York, NY: Praeger Publishers.

Lehman, J., Kern, D. C., Glaser, B., \& Woods, W. I. (Eds.). (2003). Amazonian dark earths: Origin properties management. Dordrecht, Netherlands: Kluwer Academic Publishers.

Leidelmeyer, P. (1966). The Paleocene and lower Eocene of pollen flora of Guyana. Leidse Geologische Mededelingen, 38, 49-70.

Lentz, D. L., Beaudry-Corbett, M. P., de Aguilar, M. L. R., \& Kaplan L. (1996). Foodstuffs, forests, fields, and shelter: A paleoethnobotanical analysis of vessel contents from the Ceren site, El Salvador. Latin American Antiquity, 7, 247-262. http://dx.doi.org/10.2307/971577

Liddle, R. A. (1946). The geology of Venezuela and Trinidad (2nd ed.). Ithaca, NY: Paleontological Research Institution.

Lopez, C. E. (2008). Landscape development and evidence for early human occupation in the Inter-andean lowlands of the Magdalena River. Miami, FL: Syllaba Press.

Lopez, V. M., Hedberg, H. D., \& Kehrer, L. (1956). Venezuela. In W. F. Jenks (Ed.), Handbook of South American geology, Geological Society of America Memoir, (Vol. 65, pp. 327-350). New York, NY: Geological Society of America.

Lorenzi, H. (2002). Brazilian trees: A guide to the identification and cultivation of Brazilian native trees. 2 Vols. Novo Odessa, SP, Brazil: Instituto Plantarum de Estudos da Flora Ltd.

MacNeish, R. S. (1965). The origins of American agriculture. Antiquity, 39, 87-94.

Malapa, R., Noyer, J. L., Marchand, J. L., \& Lebot V. (2006). Genetic relationship between Dioscorea alata L. and D. nummularia Lum. as revealed by AFPL markers. In T. J. Motley, N. Zerega, \& H. Cross (Eds.), Darwin's harvest: New approaches to the origins, evolution, and conservation of crops (pp. 239-265). New York, NY: Columbia University Press.

Maslin, M. A., Ettwein, V. J., Boot, C. S., Bendle, J., \& Pancost, R. D. (2012). Amazon Fan biomarker evidence against the Pleistocene rainforest refuge hypothesis? Journal of Quaternary Science, 27, 451-460. http://dx.doi.org/10.1002/jqs.1567

McKey, D., Rostain, S., Iriarte, J., Glaser, B., Birk, J. J., Holst, I., \& Renard, D. (2010). Pre-columbian agricultural landscapes, ecosystem engineers, and self-organized patchiness in Amazonia. Proceedings of the National Academy of Sciences, 107, 7823-7828.

Medina, E. (1980). Ecology of tropical American savannas: An ecophysiological approach. In D. Harris (Ed.), Human ecology in savanna environments (pp. 297-319.) New York, NY: Academic Press.

Méndez, C. (2013). Terminal Pleistocene/early Holocene ${ }^{14} \mathrm{C}$ dates from archaeological sites in Chile: Critical chronological issues for the initial peopling of the region. Quaternary International, 301, 60-73. http://dx.doi.org/10.1016/j.quaint.2012.04.003

Mickleburgh, H. L., \& Pagán-Jiménez, J. R. (2012). New insights into the consumption of maize and other food plants in the Pre-columbian Caribbean from starch grains trapped in human dental calculus. Journal of Archaeological Science, 39, 2468-2478. http://dx.doi.org/10.1016/j.jas.2012.02.020

Migliazza, E. C. (1985). Languages of the Orinoco-Amazon region: Current status. In H. E. Manelis Klein, \& L. R. Stark (Eds.), South American Indian languages: Retrospect and prospect (pp. 17-139). Austin, TX: University of Texas Press.

Moore, J.D. (2014). A prehistory of South America: Ancient cultural diversity on the least known continent. Boulder, CO: University Press of Colorado. 
Mora, S. (2003). Early inhabitants of the Amazonian tropical rainforest: A study of humans and environmental dynamics. University of Pittsburgh Latin American Archaeology Reports No. 3. Pittsburgh, PA: University of Pittsburgh Press.

Mora, S., Herrera, L. F., Cavelier, I., \& Rodríquez, C. (1991). Cultivars, anthropic soils, and stability: A preliminary report of archaeological research in Araracuara, Columbian Amazonia. University of Pittsburgh Latin American Archaeology Reports No. 2. Pittsburgh, PA: University of Pittsburgh Press.

Mora-Urpí, J., Weber, J. C., \& Clement, C. R. (1997). Peach palm Bactris gasipaes Kunth (Vol. 20). Bioversity International.

Morcote-Ríos, G., \& Bernal, R. (2001). Remains of palms (Palmae) at archaeological sites in the New World: A review. The Botanical Review, 67, 309-350.

Morcote-Ríos, G., Aceituno, F. J., \& Sicard, T. L. (2014). Recolectores del Holoceno temprano en la floresta Amazónica Colombiana. In S. Rostain (Ed.), Antes de Orellana. Actas del 3er Encuentro Internacional de Arqueología Amazónica (pp. 39-50). Quito, Ecuador: Instituto Francés de Estudios Andinos.

Navarrete, R. (2008). The prehistory of Venezuela-not necessarily an intermediate area. In H. Silverman, \& W. H. Isbell (Eds.), The handbook of South American archaeology (pp. 429-458). New York, NY: Springer.

Newsom, L. A. (2006). Caribbean maize: First farmers to Columbus. In J. Staller, R. Tykot, \& B. Benz (Eds.), Histories of maize: Multidisciplinary approaches to the prehistory, linguistics, biogeography, domestication, and evolution of maize (pp. 325-335). Burlington, MA: Academic Press.

Nimuendajú, C. (2004). In pursuit of a past Amazon: Archaeological researches in the Brazilian Guyana and in the Amazon region. S. Rydén, \& P. Stenborg (Eds. and trans.). Göteborg, Sweden: Etnologiska Studier No. 45.

Occupational Safety and Health Administration [OSHA] (2005). Chemical Sampling Information: Starch (Total Dust). Chemical Sampling Information. Washington, DC: US Department of Labor, Occupational Safety and Health Administration.

Oliver, J. R. (2008). The archaeology of agriculture in ancient Amazonia. In H. Silverman, \& W. H. Isbell (Eds.), The handbook of South American archaeology (pp. 185-216). New York, NY: Springer.

Oliver, J. R. (2014). Nuevos aportes a la arqueología del sitio El Saladero, bajo Orinoco, Venezuela. In S. Rostain (Ed.), Antes de Orellana. Actas del Ber Encuentro Internacional de Arqueologia Amazónica (pp. 97-112). Quito, Ecuador: Instituto Francés de Estudios Andinos.

Olsen, K. M., \& Schaal, B. A. (1999). Evidence on the origin of cassava. Phylogeography of Manihot esculenta. Proceedings of the National Academy of Sciences, 96, 5586-5591. http://dx.doi.org/10.1073/pnas.96.10.5586

Olsen, K. M., \& Schaal, B. A. (2006). DNA sequence data and inferences on cassava's origin of domestication. In M. Zeder, D. G. Bradley, E. Emshwiller, \& B. C. Smith (Eds.), Documenting domestication: New genetic and archaeological paradigms (pp. 123-133). Berkeley, CA: University of California.

Olsson, A. A. (1956). Colombia. In W. F. Jenks (Ed.), Handbook of South American Geology, Geological Society of America Memoir, (Vol. 65, pp. 293-326). New York.

Orejuela, J. E. (1992). Traditional production systems of the Awa (Cuaiquer) Indians of southwestern Colombia and neighboring Ecuador. In K. H. Redford, \& C. Padoch (Eds.), Conservation of neotropical forests: Working from traditional resource use (pp. 58-82). New York, NY: Columbia University Press.

Osterrieth, M., Madella, M., Zurro, D., \& Alvarez, M. F. (2009). Taphonomical aspects of silica phytoliths in the loess sediments of the Argentine Pampas. Quaternary International, 193, 70-79.

Oyuela-Caycedo, A. (1996). The study of collector variability in the transition to sedentary food producers in northern Colombia. Journal of World Prehistory, 10, 49-93.

Oyuela-Caycedo, A. (2008). Late Pre-hispanic chiefdoms of northern Colombia and the formation of anthropogenic landscapes. In H. Silverman \& W. H. Isbell (Eds.), The handbook of South American archaeology (pp. 405-428). New York, NY: Springer.

Oyuela-Caycedo, A., \& Bonzani, R. M. (2005). San Jacinto 1. A historical ecological approach to an archaic site in Colombia. Tuscaloosa: University of Alabama Press.

Padoch, C., \& Pinedo-Vasquez, M. (1999). Farming above the flood in the várzea of Amapá: Some preliminary 
results of the Projeto Várzea. In C. Padoch, J. M. Ayres, M. Pinedo-Vasquez, \& A. Henderson (Eds.), Várzea: Diversity, development, and conservation of Amazonia's whitewater floodplains, Advances in Economic Botany (Vol. 13 pp. 345-354). New York, NY: New York Botanical Garden.

Pagán-Jiménez, J. R. (2012). Early use of maize and other food crops among early ceramic and later Neoindian traditions in northeastern Amazonia revealed by ancient starch grains from ceramic and lithic artifacts of the Chemin Saint-Louis archaeological site. Archaeology and Anthropology, 17, 78-107.

Pagán-Jiménez, J. R., Rodriguez-Ramos, R., Reid, B. A., van den Bel, M., \& Hofman, C. L. (2015). Early dispersals of maize and other food plants into the southern Caribbean and northeastern South America. Quaternary Science Reviews, 123, 231-246. http://dx.doi.org/10.1016/j.quascirev.2015.07.005

Paper Academy (2012). Starch for paper: Products and market figures. Paper Technical Database.

Pearsall, D. M. (1995) Domestication and agriculture in the New World tropics. In T. D. Price, \& A. B. Gebauer (Eds.), Last hunters-first farmers: New perspectives on the prehistoric transition to agriculture (pp. 157-192). Santa Fe, NM: SAR Press.

Pearsall, D. M. (2000). Paleoethnobotany: A handbook of procedures. San Diego, CA: Academic Press.

Pearsall, D. M. (2007). Modeling prehistoric agriculture through the paleoenvironmental record: Theoretical and methodological issues. In J. Iriarte, T. Denham, \& L. Vrydaghs (Eds.), Rethinking agriculture: Archaeological and ethnoarchaeological perspectives (pp. 210-230). Walnut Creek, CA: Left Coast Press.

Perry, L. (2002a). Starch analyses reveal multiple functions of quartz "manioc" grater flakes from the Orinoco basin, Venezuela. Interciencia, 27, 635-639.

Perry, L. (2002b). Starch granule size and the domestication of manioc (Manihot esculenta) and sweet potato $\begin{array}{lllll}\text { (Ipomoea } \quad \text { batatas). } & \text { Botany, } & \text { 335-349. }\end{array}$ http://dx.doi.org/10.1663/0013-0001(2002)056\%5B0335:SGSATD\%5D2.0.CO;2

Perry, L. (2004). Starch analyses reveal the relationship between tool types and function: An example from the Orinoco valley of Venezuela. Journal of Archaeological Science, 31, 1069-1081. http://dx.doi.org/10.1016/j.jas.2004.01.002

Pestle, W. J., \& Colvard, M. (2012). Bone collagen preservation in the tropics: a case study from ancient Puerto Rico. Journal of Archaeological Science, 39, 2079-2090. http://dx.doi.org/10.1016/j.jas.2012.03.008

Piperno, D. R. (1990). Aboriginal agriculture and land usage in the Amazon Basin, Ecuador. Journal of Archaeological Science, 17, 665-677.

Piperno, D. R. (1995). Plant microfossils and their application in the New World tropics. In P.W. Stahl (Ed.), Archaeology in the lowland American tropics: Current analytical methods and recent applications (pp. 130-153). Cambridge: Cambridge University.

Piperno, D. R. (2006). Phytoliths: A comprehensive guide for archaeologists and paleoecologists. London, UK: AltaMira Press.

Piperno, D. R. (2011). The origins of plant cultivation and domestication in the American New World tropics. Current Anthropology, 52, (S4), S453-S470.

Piperno, D. R., \& Becker, P. (1996). Vegetational history of a site in the central Amazon basins derived from phytolith and charcoal records from natural soils. Quaternary Research, 45, $202-209$. http://dx.doi.org/10.1006/qres.1996.0020

Piperno, D. R., \& Flannery, K. V. (2001). The earliest archaeological maize (Zea mays L.) from highland Mexico: New accelerator mass spectrometry dates and their implications. Proceedings of the National Academy of Sciences, 98, 2101-2103. http://dx.doi.org/10.1073/pnas.98.4.2101

Piperno, D. R., \& Pearsall, D. M. (1998). The origins of agriculture in the lowland neotropics. San Diego, CA: Academic Press.

Piperno, D. R., Bush, M. B., \& Colinvaux, P. A. (1990). Paleoenvironments and human occupation in late-glacial Panama. Quaternary Research, $108-116$. http://www.sciencedirect.com/science/article/pii/0033589490900894

Pires, J. M. (1984). The Amazonian forest. In H. Sioli (Ed.), The Amazon: Limnology and landscape ecology of a mighty tropical river and its basin (pp. 581-602). Dordrecht: W. Junk. http://dx.doi.org/10.1007/978-94-009-6542-3_22 
Pohl, M. E. D., Piperno, D. R., Pope, K. O., \& Jones, J. G. (2007). Microfossil evidence for Pre-columbian maize dispersals in the neotropics from San Andrés, Tabasco, Mexico. Proceedings of the National Academy of Sciences, 104, 6870-6875. http://dx.doi.org/10.1073/pnas.0701425104

Politis, G. (2009). Nukak: Ethnoarchaeology of an Amazonian people. Walnut Creek, CA: Left Coast Press.

Raffles, H. (1999). Exploring the anthropogenic Amazon: Estuarine landscape transformations in Amapá, Brazil. In C. Padoch, J. M. Ayres, M. Pinedo-Vasquez, \& A. Henderson (Eds.), Várzea: Diversity, development, and conservation of Amazonia's whitewater floodplains, Advances in Economic Botany (Vol. 13 pp. 355-370). New York, NY: New York Botanical Garden.

Rinaldi, M., \& Redmond, E. M. (2014). Report on pollen samples 54, 114, and 442. In C. S. Spencer \& E.M. Redmonds (Eds.), A Pre-hispanic chiefdom in Barinas, Venezuela: excavations at Gaván-complex sites (pp. 844-848). Anthropological papers of the American Museum of Natural History, No. 100. http://dx.doi.org/10.5531/sp.anth.0100

Rindos, D. (1984). The evolution of agriculture: An evolutionary perspective. Orlando, FL: Academic Press.

Rival, L., \& McKey, D. (2008). Domestication and diversity in manioc (Manihot esculenta Crantz ssp esculenta, Euphorbeaceae). Current Anthropology, 49, 1119-1128.

Roosevelt, A. C. (1980). Parmana: Prehistoric maize and manioc subsistence along the Amazon and Orinoco. New York, NY: Academic Press.

Roosevelt, A. C. (1984a). Population, health, and the evolution of subsistence: Conclusions. In M N. Cohen, \& G. J. Armelagos, Paleopathology at the origins of agriculture, (pp. 559-583). New York, NY: Academic Press.

Roosevelt, A. C. (1984b). Problems interpreting the spread of cultivated plants. In D. Stone (Ed.), Pre-columbian Plant Migration, Papers of the Peabody Museum of Archaeology and Ethnology, (Vol. 76, pp.1-18). Cambridge MS: Harvard University.

Roosevelt, A. C. (1989). Resource management in Amazonia before the conquest: Beyond ethnographic projection. In D. A. Posey and W. Balée (Eds.), Resource management in Amazonia: Indigenous and folk strategies, Advances in Economic Botany, (Vol. 7, pp. 30-62). New York, NY: New York Botanical Garden.

Roosevelt, A. C. (1991). Moundbuilders of the Amazon: Geophysical archaeology on Marajo Island, Brazil. San Diego, CA: Academic Press.

Roosevelt, A. C. (1994b). Amazonian anthropology: Strategy for a new synthesis. In A. C. Roosevelt (Ed.) Amazonian Indians from prehistory to the present: Anthropological perspectives (pp. 1-29). Tucson, AZ: University of Arizona.

Roosevelt, A. C. (1995). Early pottery in the Amazon: Twenty years of scholarly obscurity. In W. Barnett \& J. Hoopes (Eds.), The emergence of pottery: Technology and innovation in ancient societies, (pp.115-131). Washington, DC: Smithsonian Institution.

Roosevelt, A. C. (1997). The excavations at Corozal, Venezuela: Stratigraphy and ceramic seriation. Yale University Publications in Anthropology, No. 83.

Roosevelt, A. C. (1999). The development of prehistoric complex societies: Amazonia, a tropical forest. Archeological papers of the American Anthropological Association, 9(1), 13-33.

Roosevelt, A. C. (2000). The lower Amazon: A dynamic human habitat. In D.L. Lentz (Ed.), Imperfect balance: Landscape transformations in the Precolumbian Americas, (pp. 455-491). New York, NY: Columbia University Press.

Roosevelt, A. C. (2013). The Amazon and the Anthropocene: 13,000 years of human influence in a tropical rainforest. Anthropocene, 4, 69-87.

Roosevelt, A. C. (2014). Prehistory of Amazonia. In C. Renfrew \& P. Bahn (Eds.) Cambridge World Prehistory. (Vol. 2, pp. 1175-1199) Cambridge: Cambridge University Press.

Roosevelt, A. C. (Ed.). (1994a). Amazonian Indians from prehistory to the present: Anthropological perspectives. Tucson, AZ: University of Arizona.

Roosevelt, A. C., Douglas, J. E., \& Brown, L. J. (2002). The migrations and adaptations of the first Americans: Clovis and Pre-clovis viewed from South America. In N. G. Jablonski (Ed.), The first Americans: The Pleistocene colonization of the New World, Memoirs of the California Academy of Sciences, No. 27 (pp. 159-236). Berkeley, CA: University of California Press and the California Academy of Sciences. 
Roosevelt, A. C., Douglas, J. E., Amaral, A. M., Imazio da Silveira, M., Barbosa, C. P., Barreto, M., ... Brown, L. J. (2009). Early hunter-gatherers in the terra firme rainforest: Stemmed projectile points from the Curuá goldmines. Amazônica, 1, 422-483. http://dx.doi.org/10.18542/amazonica.v1i2.296

Roosevelt, A. C., Douglas, J., Bevan, B., Imazio da Silveira, M., \& Brown, L. (2012). Early mounds and monumental art in ancient Amazonia: history, scale, function, and social ecology. In R. L. Burger, \& R. M. Rosenswig (Eds.), Early new world monumentality (pp. 255-288). Gainesville, FL: University Press of Florida.

Roosevelt, A. C., Housley, R. A., Imazio da Silveira, M., Maranca, S., \& Johnson, R. (1991). Eighth millennium pottery from a prehistoric shell midden in the Brazilian Amazon. Science, 254,1621-1624. http://dx.doi.org/10.1126/science.254.5038.1621

Roosevelt, A. C., Krueger, H., \& Sullivan, C. (1993). Isotopic evidence for the role of maize in prehistoric Amazonian subsistence Unpublished manuscript, in author's personal files.

Roosevelt, A.C., da Costa, M. L., Machado, C. L., Michab, M., Mercier, N., Valladas, ... Schick, K. (1996). Paleoindian cave dwellers in the Amazon: The peopling of the Americas. Science, 272, 373-384. http://dx.doi.org/10.1126/science.272.5260.373

Rostain, S. (2008a). Agricultural earthworks on the French Guiana coast. In H. Silverman, \& W. H. Isbell (Eds.), The handbook of South American archaeology (pp. 217-233). New York, NY: Springer.

Rostain, S. (2008b). The archaeology of the Guianas: An overview. In H. Silverman, \& W. H. Isbell (Eds.), The handbook of South American archaeology (pp. 279-302). New York, NY: Springer.

Rostain, S. (2013a). Islands in the rainforest: Landscape management in Pre-columbian Amazonia. Walnut Creek, CA: Left Coast Press.

Rostain, S. (2013b). Aerial Amazonia: Pre-columbian landscape sculptors (Amazonia aerea escultores precolombinos del paisaje) (Amazonie aerienne sculpteurs precolombiens du paysage). Quito, Ecuador: Encuentro International de Arqueologia Amazonica.

Rouse, I., \& Cruxent, J. M. (1963). Venezuelan archaeology. New Haven, CT: Yale University Press.

Sanoja, M., \& Vargas Arenas, I. (2006). Las sociedades arcaicas del bajo Orinoco. In G. Morcote Ríos, S. Mora Camargo, \& C. Franky Calvo. (Eds.), Pueblos y paisajes antiguos de la selva Amazónica (pp. 63-80). Bogotá, Columbia: Universidade Nacional de Colombia and Washington, DC: Taraxacum.

Santos Vecino, G., Monsalve, C. A., \& Correa Salas, L. V. (2015). Alteration of tropical forest vegetation from the Pleistocene-Holocene transition and plant cultivation from the end of the early Holocene through middle Holocene in northwest Colombia. Quaternary International, 363, 28-42. http://dx.doi.org/10.1016/j.quaint.2014.09.018

Sauer, C. O. (1952). Agricultural origins and dispersals: The domestication of animals and foodstuffs. New York, NY: American Geographical Society.

Schaal, B. A., Olsen, K. M., \& Carvalho, L. J. C. B. (2006). Evolution, domestication, and agrobiodiversity in the tropical crop cassava. In T. J. Motley, N. Zerega, \& H. Cross (Eds.), Darwin's harvest: New approaches to the origins, evolution, and conservation of crops (pp. 269-294). New York, NY: Columbia University Press.

Schmink, M., \& Wood, C. H. (1992). Contested frontiers in Amazonia. New York, NY: Columbia University Press.

Schrimpff, M. C., Herrera, L., \& Bray, W. (2005). The earliest inhabitants. In M. C. Schrimpff(Ed.), Calima and Malagana: Art and archaeology in southwestern Colombia (pp. 26-35). Bogotá, Colombia: Pro Calima Foundation.

Service, E. R. (1975). Origins of the state and civilization: The process of cultural evolution. New York, NY: Norton.

Sheets, P., Dixon, C., Guerra, M., \& Blanford, A. (2011). Manioc cultivation at Ceren, El Salvador: Occasional kitchen garden plant or staple crop? Ancient Mesoamerica, 22, 1-11. http://dx.doi.org/10.1017/S0956536111000034

Shepard Jr, G. H., \& Ramirez, H. (2011). "Made in Brazil": Human dispersal of the Brazil nut (Bertholletia excelsa, Lecythidaceae) in ancient Amazonia. Economic Botany 65, 44-65. 
http://dx.doi.org/10.1007/s12231-011-9151-6

Siegel, P. E. (2010). Continuity and change in the evolution of religion and political organization on Pre-columbian Puerto Rico. Journal of Anthropological Archaeology, 29, 302-326. http://dx.doi.org/10.1016/j.jaa.2010.04.002

Smith, C. E., \& Roosevelt, A. C. (1985). Prehistoric plant use in the middle Orinoco basin: Tree crops. Unpublished manuscript, in author's personal files.

Smith, N. J. H., Vásquez, R., \& Wust, W. H. (2007). Amazon river fruits: Flavors for conservation. St. Louis. MO: Amazon Conservation Association and Missouri Botanical Garden Press.

Smole, W. J. (1976). The Yanoama Indians: A Cultural Geography. Austin: University of Texas Press.

Spencer, C. S., \& Redmond, E. M. (1992). Prehispanic chiefdoms of the western Venezuelan llanos. World Archaeology, 24, 134-157.

Spencer, C. S., \& Redmond, E. M. (1998). Prehispanic causeways and regional politics in the llanos of Barinas, Venezuela. Latin American Antiquity, 9, 95-110.

Spencer, C. S., \& Redmond, E. M. (Eds.). (2014). A Pre-hispanic chiefdom in Barinas Venezuela: Excavations at Gaván-complex sites, 2 Vols. Anthropological papers of the American Museum of Natural History, No. 100. http://dx.doi.org/10.5531/sp.anth.0100

Spencer, C. S., Redmond, E. M., \& Rinaldi, M. (1994). Drained fields at la Tigra, Venezuela llanos: A regional perspective. Latin American Antiquity, 5, 119-143.

Storey, R. (1992). Life and death in the ancient city of Teotihuacan: A modern paleodemographic synthesis. Tuscaloosa, Alabama: University of Alabama Press.

Therin, M., Fullagar, R., \& Torrence, R. (1999). Starch in sediments: A new approach to the study of subsistence and land use in Papua New Guinea. In C. Gosden, \& J. Hather (Eds.), The Prehistory of Food: Appetites for Change, (pp. 438-462). London, UK: Routledge.

Torrence, R., \& Barton, H. (Eds.). (2006). Ancient starch research. Walnut Creek, CA: Left Coast Press.

U. S. Food and Drug Administration [USFDA] (1997). Medical glove powder report. Silver Spring, MD.

van den Bel, M. M. (2015). Archaeological investigations between Cayenne Island and the Maroni River: A cultural sequence of western coastal French Guiana from 5000 BP to present (Doctoral dissertation, University of Leiden. Leiden, Netherlands). Retrieved from https://openaccess.leidenuniv.nl/handle/1887/35054

van der Hammen, T., \& Hooghiemstra, H. (2000). Neogene and Quaternary history of vegetation, climate, and plant diversity in Amazonia. Quaternary Science Reviews, 19, 725-742.

van der Merwe, N., Roosevelt, A. C., \& Vogel, J. C. (1981). Isotopic evidence for prehistoric subsistence change at Parmana, Venezuela. Nature, 292, 536-538.

Versteeg, A. H. (1978). A distinctive kind of pottery in western Suriname. Mededelingem Surinaams Museum, 29, 16-27.

Versteeg, A. H. (1998). The Archaeology of St. Eustatius. Paramaribo: Stichting Surinaams Museum. Publications of the St. Eustatius Historical Foundation, No. 5

Versteeg, A. H. (2008). Barrancoid and Arauquinoid mound builders in coastal Suriname. In H. Silverman, \& W. H. Isbell (Eds.), The handbook of South American archaeology (pp. 303-318). New York, NY: Springer.

Versteeg, A. H., \& Rostain, S. (1999). A hafted Amerindian stone axe recovered from the Suriname river. Mededelingen Surinaams Museum, 55.

Versteeg, A.H., \& Bubberman, F.C., (1992). Suriname before Columbus. Mededelingen Stichting Surinaams Museum 49A, (pp. 3-65), Paramaribo, Suriname. Updated Internet version 1998.

Whittington, S. L., \& Reed, D. M. (Eds.) (2006). Bones of the Maya: Studies of ancient skeletons. Tuscaloosa, Alabama: University of Alabama Press.

Willerslev, E., Davison, J., Moora, M., Zobel, M., Coissac, E., Edwards, M. E., ... \& Craine, J. (2014). Fifty thousand years of Arctic vegetation and megafaunal diet. Nature, 506(7486), 47-51. http://dx.doi.org/10.1038/nature12921

Wright, P. J. (2010). Methodological issues in paleoethnobotany: A consideration of issues, methods, and cases. 
In A. M. Vanderwarker, \& T. M. Peres (Eds.), Integrating zooarchaeology and paleobotany: A consideration of issues, methods, and cases (pp. 37-64). New York, NY: Springer.

Zucchi, A., \& Denevan, W. M. (1979). Campos elevados e historia cultural prehispánica en los llanos occidentales de Venezuela. Caracas, Venezuela: Universidad Católica Andrés Bello, Instituto de Investigaciones Históricas.

\section{Copyrights}

Copyright for this article is retained by the author(s), with first publication rights granted to the journal.

This is an open-access article distributed under the terms and conditions of the Creative Commons Attribution license (http://creativecommons.org/licenses/by/4.0/). 